NISTIR 5445

\title{
Feasibility of Fire Evacuation by Elevators at FAA Control Towers
}

John H. Klote

Bernard M. Levin

Norman E. Groner
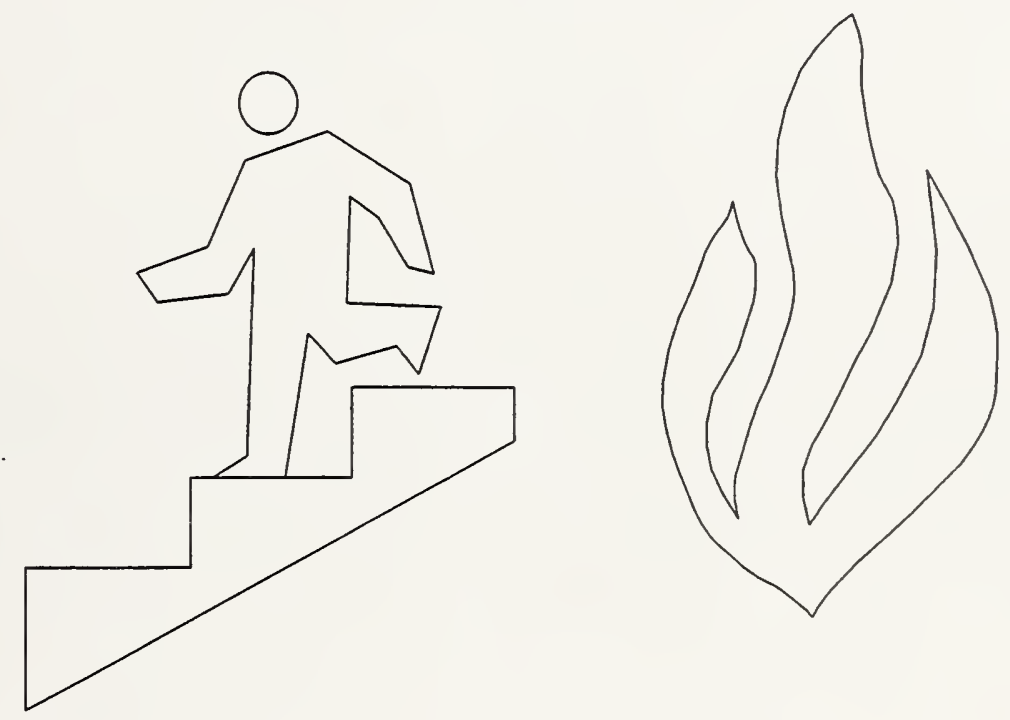

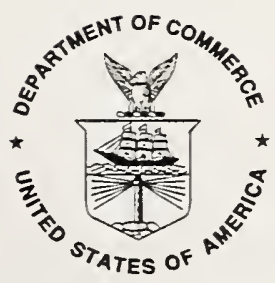

J.S. Department of Commerce 'echnology Administration

.056 Jational Institute of Standards and Technology

N0.5445 iaithersburg, MD 20899

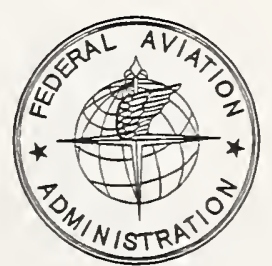

Prepared for:

U.S. Department of Transportation

Federal Aviation Administration

Engineering and Environmental Safety Division

Washington, DC 20591 



\section{NISTIR 5445}

\section{Feasibility of Fire Evacuation by Elevators at FAA Control Towers}

John H. Klote

Building and Fire Research Laboratory

Gaithersburg, Maryland 20899

Bernard M. Levin

Norman E. Groner

George Mason University

Fairfax, Virginia 22030

May 1994

Issued August 1994

\section{U.S. Department of Commerce}

Ronald H. Brown, Secretary

Technology Administration

Mary L. Good, Under Secretary for Technology

National Institute of Standards and Technology

Arati Prabhakar, Director
Prepared for:

U.S. Department of Transportation

Frederico Peña, Secretary

Federal Aviation Administration

David Hinson, Administrator

NAS Transition and Implementation Service

Engineering and Environmental Safety Division 



\section{Table of Contents}

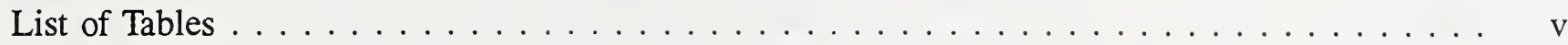

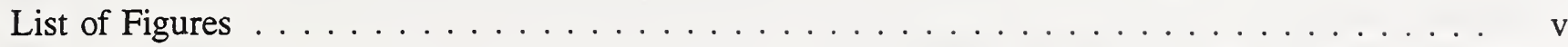

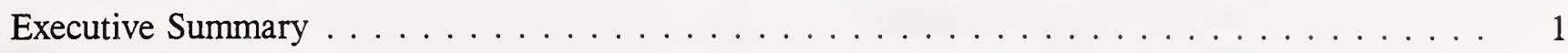

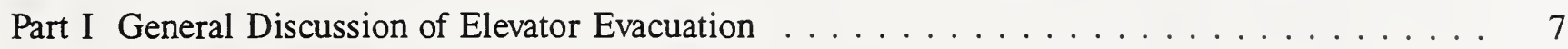

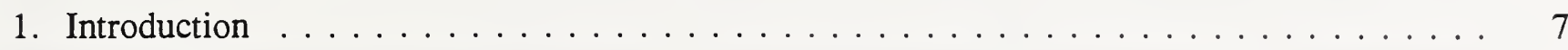

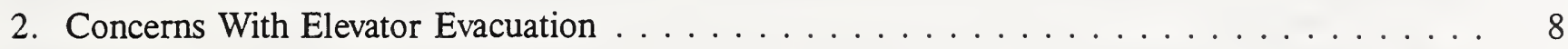

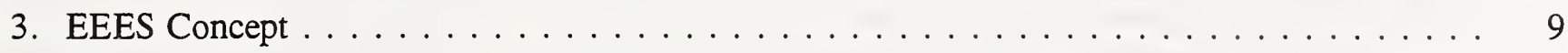

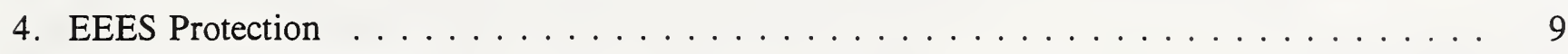

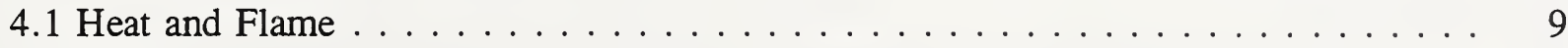

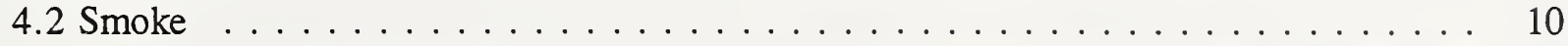

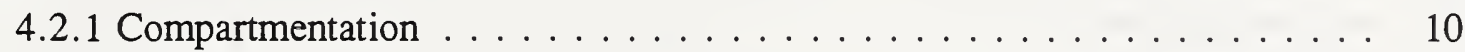

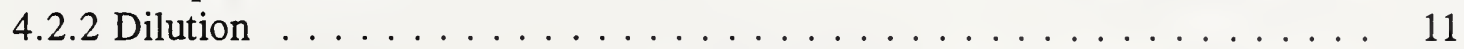

4.2 .3 Pressurization . . . . . . . . . . . . . . . . . . . 11

4.2.4 Joint U.S./Canadian Research . . . . . . . . . . . . . . . . . 11

4.2 .5 Elevator Doors Jamming . . . . . . . . . . . . . . . . . . 11

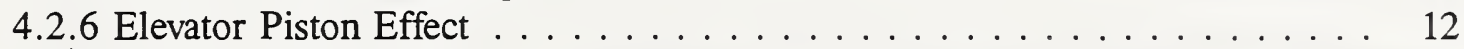

4.2 .7 Pressure Fluctuations . . . . . . . . . . . . . . . . . . . 13

4.2 .8 Smoke Control Systems . . . . . . . . . . . . . . . . . . . . . . . . 14

4.3 Water . . . . . . . . . . . . . . . . . . . . . . . . . . 15

4.3 .1 Water Exposure . . . . . . . . . . . . . . . . . . . 16

4.3.2 Water Resistive Elevator Components . . . . . . . . . . . . . . . . . . 17

4.3 .3 Prevention of Water Entry . . . . . . . . . . . . . . . . 18

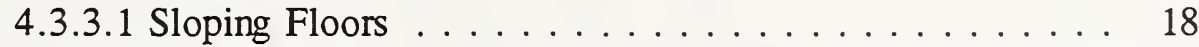

4.3.3.2 Floor Drains . . . . . . . . . . . . . . . . . 19

4.3.3.3 Flow Under Doors . . . . . . . . . . . . . . . . 19

4.3.3.4 Possible Approach . . . . . . . . . . . . . . . . 22

4.3 .4 Exterior Elevators . . . . . . . . . . . . . . . . . . . . . 23

4.3.5 Smokeproof Enclosures by Natural Ventilation . . . . . . . . . . . . . 23

4.4 Overheating of Elevator Machine Room Equipment . . . . . . . . . . . . . . . 24

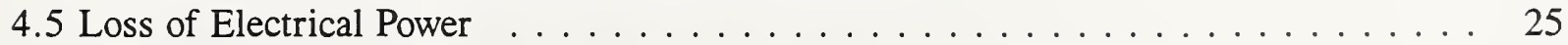

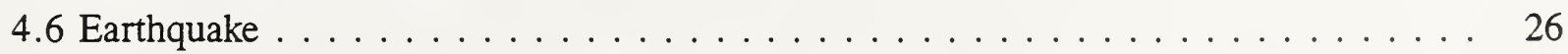

5. Availability . . . . . . . . . . . . . . . . . . . . . . . . . 29

6. Elevator Control . . . . . . . . . . . . . . . . . . . . . . . . . . . . 29 
7. Human Considerations . . . . . . . . . . . . . . . . . . . . . 31

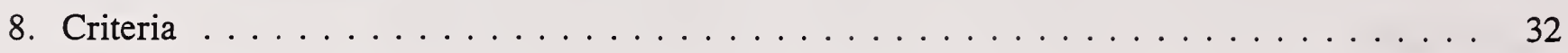

9. Retrofit ATCTs ................................ 33

9.1 Standard and Non-Standard Designs . . . . . . . . . . . . . . . . . 34

9.2 Location of Top Elevator Landing . . . . . . . . . . . . . . . . . . 35

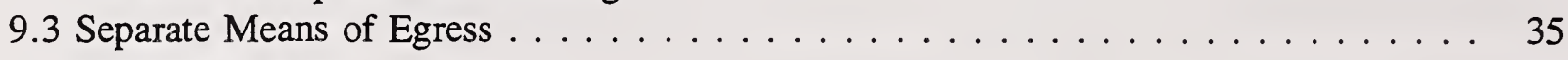

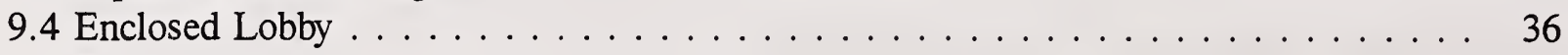

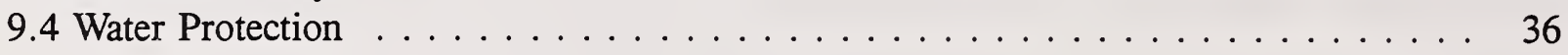

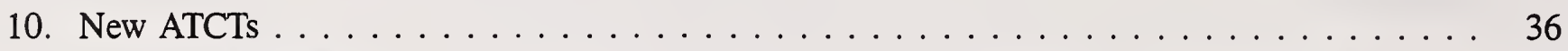

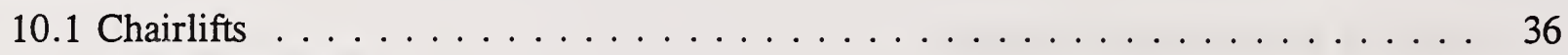

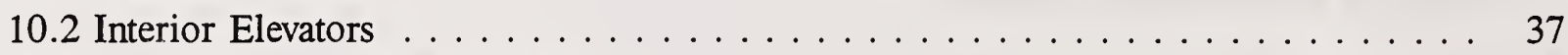

- 10.3 Modified Sidewalk Type Elevator . . . . . . . . . . . . . . . . . 37

10.4 Exterior Elevators . . . . . . . . . . . . . . . . . . . . 37

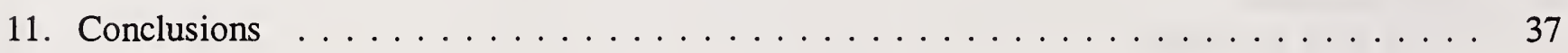

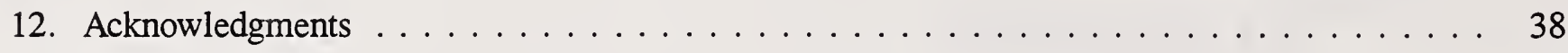

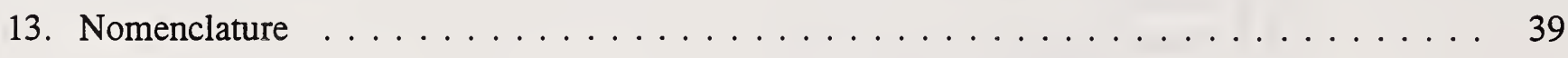

14. References $\ldots \ldots \ldots \ldots \ldots \ldots \ldots \ldots \ldots \ldots \ldots \ldots \ldots \ldots \ldots$

Appendix A Units of Measurement and Constants . . . . . . . . . . . . . . . . 104 


\section{List of Tables}

Table 1. Water flows of some suppression $\&$ firefighting devices . . . . . . . . . . 17

Table 2. FAA air traffic control towers visited $\ldots \ldots \ldots \ldots \ldots \ldots \ldots \ldots$

Table 3. Standard and non-standard design FAA air traffic control towers . . . . . . . . 34

\section{List of Figures}

Figure 1. Typical sign currently used to indicate that elevators should not to be used during fires .......................... 7

Figure 2. Elevator system including elevator equipment, machine room, hoistway and

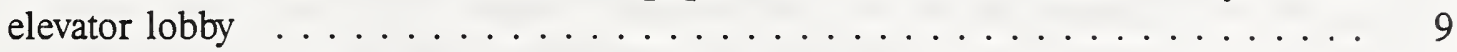

Figure 3. Elevator smoke control with a pressure relief vent $\ldots \ldots \ldots \ldots \ldots$

Figure 4. Elevator smoke control with fire floor exhaust . . . . . . . . . . . 15

Figure 5. Solid hose stream striking sloping floor . . . . . . . . . . . . . . . . 18

Figure 6. Relationship between flow and pressure difference for straight-through crack . . . 20

Figure $7 . \quad$ Flow under door exposed to standing water . . . . . . . . . . . . 21

Figure 8. Calculated flow under door exposed to standing water . . . . . . . . . . 22

Figure 9. Conceptual use of sloping floors, floor drains and doors with seals in an effort

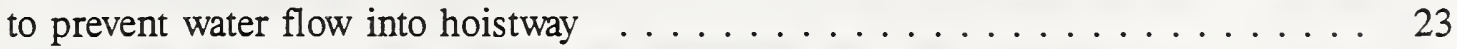

Figure 10. Use of trench floor drain to minimize water flow past drain . . . . . . . . 23

Figure 11. Elevators with exterior lobby: (a) elevator in tower separated from building, and

(b) exterior elevator separated from building. . . . . . . . . . . . . . 24

Figure 12. Seismic zone map of the United States (UBC 1993) . . . . . . . . . . . . . 27

Figure 13. Peak horizontal accelerations at ground level during the Northridge earthquake (EQE 1994) . . . . . . . . . . . . . . . . . . . . . . . 28

Figure 14. Elevation of the Leo Daly Major standard design ATCT . . . . . . . . . . . . . . 44

Figure 15. Ground floor of the Leo Daly Major standard design ATCT . . . . . . . . . . . . 45

Figure 16. Typical floor of the Leo Daly Major standard design ATCT . . . . . . . . . . . 46

Figure 17. Subjunction floor of the Leo Daly Major standard design ATCT . . . . . . . . . 47

Figure 18. Junction floor of the Leo Daly Major standard design ATCT . . . . . . . . . . . . 48

Figure 19. Cab floor of the Leo Daly Major standard design ATCT . . . . . . . . . . . 49

Figure 20. Elevation of the Welton Becket standard design ATCT . . . . . . . . . . 50

Figure 21. First floor of the Welton Becket standard design ATCT . . . . . . . . . . 51

Figure 22. Typical floor of the Welton Becket standard design ATCT . . . . . . . . . . 52

Figure 23. Subjunction floor of the Welton Becket standard design ATCT . . . . . . . . . 53

Figure 24. Junction floor of the Welton Becket standard design ATCT . . . . . . . . . . . 54

Figure 25. Cab floor of the Welton Becket standard design ATCT . . . . . . . . . . . 55

Figure 26. Elevation of the Pei standard design ATCT . . . . . . . . . . . . . 56

Figure 27. Ground floor of the Pei standard design ATCT . . . . . . . . . . . . . 57

Figure 28. Typical floor of the Pei standard design ATCT . . . . . . . . . . . 58

Figure 29. Cab floor of the Pei standard design ATCT . . . . . . . . . . . . 59 
Figure 30 .

Figure 31.

Figure 32.

Figure 33.

Figure 34.

Figure 35.

Figure 36.

Figure 37.

Figure 38.

Figure 39.

Figure 40.

Figure 41.

Figure 42.

Figure 43.

Figure 44.

Figure 45.

Figure 46.

Figure 47 .

Figure 48.

Figure 49.

Figure 50.

Figure 51.

Figure 52.

Figure 53.

Figure 54.

Figure 55.

Figure 56.

Figure 57.

Figure 58.

Figure 59.

Figure 60.

Figure 61 .

Figure 62.

Figure 63.

Figure 64.

Figure 65.

Figure 66.

Figure 67.

Figure 68.

Figure 69.

Figure 70.

Figure 71.

Figure 72.

Figure 73.
Elevation of the LART standard design ATCT $\ldots \ldots \ldots \ldots \ldots \ldots \ldots$

Ground floor of the LART standard design ATCT $\ldots \ldots \ldots \ldots \ldots \ldots \ldots 6$

Typical floor of the LART standard design ATCT $\ldots \ldots \ldots \ldots \ldots \ldots \ldots 62$

Junction floor of the LART standard design ATCT $\ldots \ldots \ldots \ldots \ldots \ldots \ldots .63$

Cab floor of the LART standard design ATCT $\ldots \ldots \ldots \ldots \ldots \ldots . \ldots 64$

Elevation of the Mock standard design ATCT . . . . . . . . . . . . 65

Ground floor of the Mock standard design ATCT . . . . . . . . . . . 66

Typical floor of the Mock standard design ATCT . . . . . . . . . . . . 67

Junction floor of the Mock standard design ATCT $\ldots \ldots \ldots \ldots \ldots \ldots .68$

Cab floor of the Mock standard design ATCT . . . . . . . . . . . . . . 69

Elevation of the Golman Rolf standard design ATCT . . . . . . . . . . . 70

Ground floor of the Golman Rolf standard design ATCT $\ldots \ldots \ldots \ldots \ldots . .71$

Typical floor of the Golman Rolf standard design ATCT . . . . . . . . . . 72

Junction floor of the Golman Rolf standard design ATCT . . . . . . . . . . 73

Cab floor of the Golman Rolf standard design ATCT . . . . . . . . . . 74

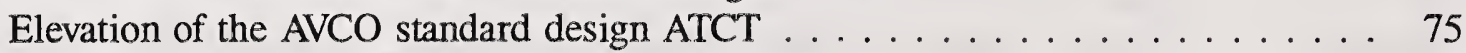

Ground floor of the AVCO standard design ATCT $\ldots \ldots \ldots \ldots \ldots \ldots 76$

Typical floor of the AVCO standard design ATCT $\ldots \ldots \ldots \ldots \ldots \ldots \ldots . .77$

Junction floor of the AVCO standard design ATCT $\ldots \ldots \ldots \ldots \ldots \ldots \ldots 78$

$\mathrm{Cab}$ floor of the AVCO standard design ATCT . . . . . . . . . . . 79

Elevation of the Leo Daly Low Activity standard design ATCT . . . . . . . . 80

Ground floor of the Leo Daly Low Activity standard design ATCT . . . . . . . 81

Typical floor of the Leo Daly Low Activity standard design ATCT . . . . . . . 82

Junction floor of the Leo Daly Low Activity standard design ATCT . . . . . . 83

Cab floor of the Leo Daly Low Activity standard design ATCT . . . . . . . . . . 84

Elevation of the Type $\mathrm{O}$ standard design ATCT $\ldots \ldots \ldots \ldots \ldots \ldots \ldots$

Ground floor of the Type $\mathrm{O}$ standard design ATCT $\ldots \ldots \ldots \ldots \ldots \ldots 86$

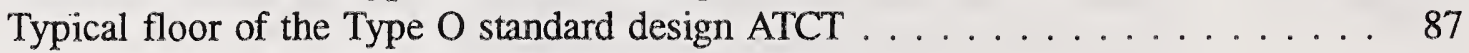

Junction floor of the Type $\mathrm{O}$ standard design ATCT $\ldots \ldots \ldots \ldots \ldots \ldots .88$

$\mathrm{Cab}$ floor of the Type $\mathrm{O}$ standard design ATCT $\ldots \ldots \ldots \ldots \ldots \ldots \ldots . . \ldots 9$

Elevation of the Oakland Metro ATCT . . . . . . . . . . . . . . 90

Ninth floor of the Oakland Metro ATCT $\ldots \ldots \ldots \ldots \ldots \ldots \ldots \ldots . . \ldots 1$

Tenth floor of the Oakland Metro ATCT $\ldots \ldots \ldots \ldots \ldots \ldots \ldots \ldots . \ldots 2$

Cab floor of the Oakland Metro ATCT . . . . . . . . . . . . . . 93

Elevation of the Dulles ATCT . . . . . . . . . . . . . . . . . . . 94

Typical floor of the Dulles ATCT $\ldots \ldots \ldots \ldots \ldots \ldots \ldots \ldots . \ldots 9$

11 th floor of the Dulles ATCT $\ldots \ldots \ldots \ldots \ldots \ldots \ldots \ldots \ldots$

12th floor of the Dulles ATCT $\ldots \ldots \ldots \ldots \ldots \ldots \ldots \ldots$. . . . . . . 97

13th floor of the Dulles ATCT $\ldots \ldots \ldots \ldots \ldots \ldots \ldots \ldots \ldots . \ldots 9$

Cab floor of the Dulles ATCT . . . . . . . . . . . . . . . . . . . 99

Elevation of the Baltimore Washington International ATCT . . . . . . . . 100

Typical floor of the Baltimore Washington International ATCT . . . . . . . . 101

8th floor of the Baltimore Washington International ATCT . . . . . . . 102

$\mathrm{Cab}$ floor of the Baltimore Washington International ATCT . . . . . . . 103 


\section{Feasibility of Fire Evacuation by Elevators at FAA Control Towers}

\section{Executive Summary}

Throughout most of the world, warning signs next to elevators indicate they should not be used in fire situations. Because these elevators have not been designed for fire evacuation, they should not be used for fire evacuation. However, the idea of using elevators for fire evacuation has gained considerable attention. The Federal Aviation Administration (FAA) has sponsored a project to study the feasibility of elevator emergency evacuation at air traffic control towers (ATCTs) for people without mobility limitations. This project addresses both existing and new ATCTs. This paper describes this project including a general discussion of elevator evacuation, presentation of conceptual criteria for such elevator evacuation systems, and application of that criteria to several ATCTs.

In addition to the feasibility study of this report, the FAA has a separate effort to upgrade life safety at ATCTs which includes evaluations of each ATCT conducted by a licensed fire protection engineer. The equivalency approach is being used for these evaluations. This approach consists of providing an equivalent level of safety to that provided by a facility meeting code requirements. The code used is NFPA 101 (1994) Life Safety Code, because the FAA (1988) references this document for design criteria. Accordingly this feasibility study does not evaluate equivalent approaches to life safety.

In this paper, the term emergency elevator evacuation system (EEES) is used to denote an elevator system engineered for transport of building occupants in an orderly manner to a location of safety during a fire emergency. In general, EEESs discussed in this paper are for evacuation of relatively small numbers of people as would occur in evacuation of an ATCT.

EEES Concept: An EEES includes the elevator equipment, hoistway (elevator shaft), machine room, and other equipment and controls needed for safe operation of the elevator during the evacuation process. Because people must be protected from fire and smoke while they wait for an elevator, the system must include protected elevator lobbies. Such protected elevator lobbies also help to prevent the fire from activating elevator buttons which could result in the elevator being called by the fire to the fire floor.

An EEES must have protection from heat, flame, smoke, water, overheating of elevator machine room equipment, and loss of electrical power. In addition, an EEES must have a control approach to assure protection of people traveling in the elevator. In areas of high seismic activity, attention must be paid to earthquake design. Further, the development of an EEES needs to take into account human behavior so that building occupants will be willing and capable to operate the system in an emergency.

Protection from Heat and Flame: Compartmentation is one of the oldest methods of fire protection and has been extensively used to limit the spread of fire. Buildings are divided into compartments formed by fire barriers. These barriers are walls, partitions and floor-ceiling assemblies that have a level of fire resistance. In general, stairs connecting three stories or less are required to be separated from the rest 
of the building by 1 hour fire barriers, and stairs connecting four or more stories are required to be separated by 2 hour fire barriers. The requirement for other shafts including hoistways in new construction is the same. To be equivalent with NFPA 101 compartmentation requirements, an EEES four stories or taller would need 2 hour barriers separating the hoistway, elevator lobbies and machine room from the rest of the building.

Protection from Smoke: The mechanisms that can be used to provide smoke protection are air flow, buoyancy, compartmentation, dilution and pressurization. Systems that rely on air flow or buoyancy are inappropriate for smoke protection of EEESs. Compartmentation and dilution can be applied to EEESs, but they require analysis of smoke leakage, toxicity and evacuation. No testing technique has been developed that can assure that compartmentation systems or dilution systems will work as intended. Systems relying on compartmentation with pressurization are designed on the basis of no smoke leakage into protected spaces. Accordingly, analysis of such pressurization systems is less complex than that of systems using compartmentation alone or compartmentation with dilution. Acceptance testing and routine testing of pressurization systems is done by measurement of the pressure difference produced when the system is operating. Such testing provides a level of assurance about system performance during a fire. For systems that have windows breaking, windows opening, or doors opening to the outside; the following types of smoke control systems can maintain pressurization during such pressure fluctuations: a Pressure-Relief Vent System, a Barometric Damper System, a Variable-Supply Air System, and a System with Fire Floor Venting or Exhaust.

Protection from Water: During a building fire water from sprinklers and fire hoses can damage electronic, electrical, and mechanical components of an EEES. If there is a fire in the hoistway, elevator lobbies or machine room; the EEES should be shut down. For fires outside the EEES, the two major locations of concern about water damage are the machine room and the hoistway. Two potential approaches to minimize water damage are:

1. use of elevator components that can function in a wet environment, and

2. prevention of water from entering the hoistway or machine room.

Water can be kept from entering the hoistway (elevator shaft) by the combined use of sloping floors, floor drains and doors with seals to prevent water flow into hoistway. Currently no elevators have been developed with water resistant components for operation during fire evacuations. However, many elevators operate outdoors on exterior walls of buildings with many of the system components exposed to rain, wind and extremes of temperature. These outdoor conditions are believed to be much more severe than those associated with water flow inside a hoistway due to a building fire. Without routine testing for water resistance, components that degraded from years of use or were accidentally damaged would go undetected and unrepaired. Further research may result in improved understanding of hoistway water flow, methods of developing water resistant elevator components and appropriate tests. Until such water resistance technology is developed for elevator evacuation, the only practical approaches are (1) prevention of water from entering the hoistway, (2) the use of exterior elevators, and (3) the use of elevators with exterior lobbies.

Overheating of Elevator Machine Room Equipment: Loss of cooling can result in loss of elevator service due to overheating of elevator equipment, and precautions need to be taken to minimize the likelihood of such overheating. The maximum operating temperatures of most elevator equipment are in the range of 30 to $35^{\circ} \mathrm{C}\left(86\right.$ to $\left.95^{\circ} \mathrm{F}\right)$. There are several approaches to providing the necessary machine room cooling, but dedicated air conditioning equipment has significant advantages. Dedicated 
equipment located in the machine room or outside the building eliminates the possibility of damage to this equipment from fire outside the machine room to the extent that the fire resistive construction withstands the fire. Further, dedicated equipment uses less electrical power than non-dedicated equipment with resulting advantages concerning reliability of electrical power.

Loss of Electrical Power: Reliability of electric power consists of assuring a source of power and assuring continued distribution of power to where it is used. Some components that can be used to ensure reliability of power are fire protected distribution, redundant feeds, power from multiple substations outside the building, and emergency generator sets. Because elevator evacuation can tolerate short duration power loss, uninterruptable power supplies are not necessary. Any consideration of reliability of electric power should consider potential causes of power failure and the consequences of that failure.

Earthquake Protection: Part XXIV of the ASME A17.1 Elevator Code (ASME 1993) addresses seismic requirements for elevators. In seismic zones 3 or greater, a major concern is a collision between the elevator car and the counterweight that has been dislodged from its rails. Strengthening of rails and other structural elements are required for these zones such that they can withstand a horizontal acceleration of $1 / 2 g$ or greater ${ }^{1}$. Additionally, if a seismic switch senses significant acceleration, elevators are put into an emergency mode to prevent collision with the counterweight and then taken out of service. During major earthquakes, there are many locations where accelerations are lower than $1 / 2 g$, and elevators at these locations continue to operate as normal.

While it is theoretically possible to develop elevators that could operate through much higher accelerations, development of such elevators would be a large effort, and there is no assurance that such elevators would be affordable. Further research is needed in this area.

The earthquake requirements of ASME A17.1 only apply to new buildings. It is recommended that this approach to seismic protection be used for EEESs in seismic zones 3 or greater.

Availability: When an elevator in an EEES is out of service for scheduled or unscheduled maintenance, it cannot be used for evacuation. If there are many elevators in a building, the number of elevators used for evacuation can be selected to allow for a percentage that may be out of service. In buildings with only one elevator, the above redundancy approach to assuring availability is not possible. Two other approaches to maximize availability are off hours maintenance and short turn around repairs.

Elevator Control: The ASME A17.1 has two modes of elevator operation related to fire: elevator recall (Phase I) and firefighters operation (Phase II). Some approaches that might be used to control elevators during an elevator emergency evacuation are:

1. normal use (with less sensitive detectors),

2. Phase II, and

3. other mode of elevator operation.

In an EEES, the elevator (including the elevator lobbies, hoistway and machine room) is protected from the fire effects as discussed above. Thus the elevator is operating in an environment without fire. There

${ }^{1} g$ is the acceleration of gravity, which is about $9.8 \mathrm{~m} / \mathrm{s}^{2}\left(32 \mathrm{ft} / \mathrm{s}^{2}\right)$. 
is no physical reason why an elevator so protected cannot continue to operate normally provided that a smoke detector in the elevator lobby does not go into alarm. An alarm from this smoke detector will result in Phase I elevator recall to the exit floor. Smoke detectors are very sensitive, and they can be put into alarm by a quantity of smoke so small that a person might not notice. Such small amounts of smoke may enter the lobby when lobby doors are opened for evacuation. Such low levels of smoke are not a tenability concern. To avoid unwanted elevator recall, the smoke detectors in the elevator lobbies that initiate Phase I operation can be replaced with less sensitive detectors such as heat detectors.

The fire service, using Phase II operation, could also use elevators for evacuation of small numbers of people. Further, it is possible that building personnel could operate the elevators under Phase II for evacuation before the fire service arrives. Use of Phase II by non-fire service people would require that the elevator operators be trained and that the general approach not adversely affect fire service operations.

For completeness, approach 3 , is listed above. As discussed in the main paper, the capabilities that might be expected in such a fire mode are not consistent with the EEESs under discussion in this paper.

Human Considerations: As part of this project, visits were made to 13 ATCTs. During these visits, interviews were conducted with air traffic controllers and facilities personnel that use the ATCT. The interviews consisted of informal discussions that lasted about 15 minutes. Considering the twenty year campaign to teach people not to use elevators during fires, it was not surprising that nearly all those interviewed expressed a strong preference for using stairs as the first choice escape route. At some ATCTs there were complaints about elevator service, and the occupants at these towers were emphatic in expressing reluctance about elevators for fire evacuation. At ATCTs with few complaints about elevator service, occupants were more willing to accept the idea of EEES. Good maintenance of an elevator will encourage people to trust an EEES.

Communication is important to inform people waiting for elevators of the status of elevator evacuation and to inform people outside the building about the status of those waiting. The communication devices need to be capable of two way conversation. In order to develop confidence in EEESs, education is needed to describe the safety features. Such education should also address general aspects of fire evacuation. This education can be by a combination of formal training classes, viewing videos, performing fire drills, reading an emergency plan and group discussions.

Criteria: There are many approaches that can be taken to elevator evacuation, and some criteria are needed to evaluate modifications to ATCT and to develop EEES at new ATCTs. For the discussions of this paper, all of the following items are needed for EEES:

a. The elevator evacuation system is separate from any other means of egress.

b. The doors between the elevator lobby and the rest of the building automatically close in the event of a building fire.

c. The hoistway, elevator machine room and elevator lobby are protected by 1 hour fire barriers for hoistways three floors or less in height and by 2 hour fire barriers for all other elevators.

d. The hoistway, elevator machine room and elevator lobby are protected from smoke with a pressurization system or with a naturally ventilated smokeproof enclosures. 
e. The hoistway and the machine room are protected from water by one of the following:

1. A combination of sealed elevator lobby doors, sloped floors, floor drains and sealing the hoistway walls.

2. Water resistive elevator components developed and approved for this application including the combination of building components (sealed elevator lobby doors, sloped floors, floor drains and sealing the hoistway walls) for which the water resistant components were developed.

3. The elevators mounted on the building exterior that normally operate in the elements plus gasketing or seals on the elevator lobby doors.

4. The hoistway separated from the building by an exterior elevator lobby at each floor (see figure $11 \mathrm{a}$ or $11 \mathrm{~b})$.

f. The machine room is cooled by air conditioning equipment dedicated to this application. This air conditioning equipment is protected by fire barriers as described in item $c$ and with electrical power as described in item $\mathrm{g}$.

g. Reliability of electrical power for the emergency elevator evacuation system is assured by a standby generator that is protected by fire barriers as described in item c. All power distribution to the elevator system is redundant and protected by fire barriers as described in item c.

h. The mode of elevator control shall be approved for the number of people intended to use the elevator during an emergency evacuation.

i. The elevator capacity is sufficient for emergency elevator evacuation.

j. In seismic zones 3 or greater, elevator equipment shall meet the seismic requirements of ASME A17.1.

Retrofit ATCTs: Many ATCTs are standard designs that are adapted to the specific airports by selection of the tower height based on the requirements of the specific airport. Non-standard designs are developed when local authorities desire the ATCT to be in architectural harmony with its surroundings. The standard and non-standard ATCTs studied in this report were evaluated for adaptation to EEES.

Some elevators open into stairs which makes it impossible for the stairs and the EEES to be separate means of egress. In order for an EEES to be a separate means of egress, a person must be able to travel to the EEES without going through any other means of egress. In most of the ATCTs, a person on the cab level must travel through the exit stairs to get to the elevator. If these exit stairs are blocked by smoke, the person cannot get to the elevator. The cab level is the top floor of an ATCT where the controllers look out of windows and control air traffic. Only two standard towers were found where a person does not need to travel from the cab through the exit stairs to get to the elevator. However, there may be variations of some other standard designs where the elevator could be a separate means of egress.

Modification of the lobby to prevent water from reaching elevator equipment is not feasible in existing towers for the reasons discussed below. These modification consist of a combination of elevator doors with seals, sloping doors and floor drains (criteria item e 1). The addition of automatic closing doors 
with seals is not complicated. However, sloping floors up to the elevator doors requires that the elevators doors be removed and reinstalled a short distance higher [possibly $50 \mathrm{~mm}(2 \mathrm{in})$ ]. This entails relocating all of the electronic and electrical connections and components that are part of the doors. Because the doors are raised the lintels above the doors must be removed and replaced with new ones. Installation of a trench floor drain would weaken the floor, and a structural analysis would have to be made to determine if it is possible to strengthen the floor to allow the drain. In addition to the considerable expense of these modifications, they would require that the elevators be out of operation for an extended period during which the building occupants would have to walk up and down the stairs. This down time would be at least several weeks, and possibly even months. Considering the complexity of these modifications and elevator down time, it is concluded that modification of the lobby to prevent water from reaching elevator equipment is not feasible.

In the event that water resistant elevator components are developed which could be installed with less extensive modifications and procedures developed to assure long term reliability, it might be possible to modify some of the towers with an EEES.

New ATCTs: The criteria discussed above can be applied to new ATCTs, and the discussions in the main paper provide information about applying that criteria. As already noted, ATCTs are restricted to people without mobility limitations. This restriction is under reevaluation by FAA and the Department of Justice. This evaluation includes issues of mobility requirements of air traffic controllers on the cab level that are beyond the scope of this paper. It is possible that at some time, the FAA may desire vertical transportation to the cab for people in wheelchairs. Some approaches to providing vertical transportation to the cab are wheelchair lifts, interior elevators, modified sidewalk type elevators, and exterior elevators.

\section{Conclusions:}

1. Elevator emergency evacuation is not feasible for existing ATCTs. This could change for some standard designs if water resistant elevator components are developed that make water protection of elevators feasible.

2. Elevator emergency evacuation is feasible for new ATCTs. However, development of elevator emergency evacuation for new ATCTs would require attention to detail concerning system protection, elevator control, occupant education and occupant communications. Elevator emergency evacuation is not yet accepted by codes (such as NFPA 101), and FAA may not want to build such systems until they are accepted. Further, it is possible that another approach to achieve life safety based on equivalency may have advantages over elevator emergency evacuation. (See the introduction of the main report about a separate effort at FAA that uses equivalency.) 


\section{Feasibility of Fire Evacuation by Elevators at FAA Control Towers}

\section{Part I General Discussion of Elevator Evacuation}

\section{Introduction}

Throughout most of the world, warning signs next to elevators indicate they should not be used in fire situations (figure 1). These elevators are not intended as means of fire egress, and they should not be used for fire evacuation (Sumka 1987). Frequently, the fire service uses elevators during fires for mobilization and rescue. The idea of using elevators to speed up emergency evacuation and to evacuate persons with disabilities has gained considerable attention (Bazjanac 1974; Bazjanac 1977; Pauls 1977; Schmidt and Klote 1982; Pauls, Gatfield and Juillet 1991; Gatfield 1991; Degenkolb 1991; and Fox 1991).

The Federal Aviation Administration (FAA) is interested in the possibility of elevator emergency evacuation as a means of improving life safety in air traffic control towers (ATCTs). The Federal Aviation Administration (FAA) has sponsored a project to study the feasibility of elevator emergency evacuation at air traffic control towers (ATCTs) for people without mobility limitations.

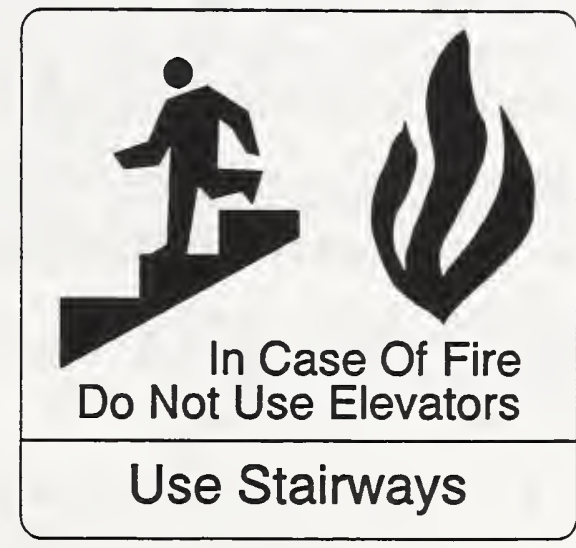

Figure 1. currently used to indicate that elevators should not to be used during fires describes this project including (1) a general discussion of elevator evacuation, (2) presentation of conceptual criteria for such elevator evacuation systems, and (3) application of that criteria to several ATCTs.

In addition to the feasibility study of this report, the FAA has a separate effort to upgrade life safety at ATCTs which includes evaluations of each ATCT conducted by a licensed fire protection engineer. The equivalency approach is being used for these evaluations. This approach consists of providing an equivalent level of safety to that provided by a facility meeting code requirements. Some of the options included in this study are early warning, pressurized stairwells, automatic closing doors, and suppression. The code used is NFPA 101 (1994) Life Safety Code, because the FAA (1988) references this document for design criteria. Accordingly this feasibility study does not evaluate equivalent approaches to life safety.

In this paper, the term emergency elevator evacuation system (EEES) is used to denote an elevator system engineered for transport of building occupants in an orderly manner to a location of safety during a fire emergency. EEES can be used for evacuation in other emergencies, for example, bomb threats. While this paper addresses fire evacuation by elevators, much of the information is applicable to elevator 
evacuation during other emergencies. EEESs can be dedicated to evacuation or they can be used for both evacuation and normal operation. This paper deals with the later. However, much of the information in the paper is also applicable to dedicated systems.

In general, EEESs discussed in this paper are for evacuation of relatively small numbers of people as might occur in evacuation of people with mobility limitations from many office buildings or in evacuation of an ATCT. However, the concepts apply to general building evacuation by elevators, and in a few places there are discussions specifically about general evacuation. General building evacuation by elevators is discussed by Klote, Alvord, Levin and Groner (1992).

The information in this paper is intended for both sprinklered and unsprinklered buildings. As discussed at the NIST Elevator Workshop (Klote, Deal, Levin, Groner, and Donoghue 1992), even though elevator evacuation technology may be primarily aimed at sprinklered buildings, information about elevator protection in unsprinklered buildings is also needed.

\section{Concerns With Elevator Evacuation}

The 1976 edition of the Life Safety Code (NFPA 101 1976) listed the following "problems" involved with the use of elevators as fire exits ${ }^{2}$ :

- Persons seeking to escape from a fire by means of an elevator may have to wait at the elevator door for some time, during which they may be exposed to fire, smoke or developing panic.

- Automatic elevators respond to the pressing of buttons in such a way that it would be quite possible for an elevator descending from floors above a fire to stop automatically at the floor involved in the fire and open automatically, exposing occupants to fire and smoke.

- Modern elevators cannot start until doors are fully closed. A large number of people seeking to crowd into an elevator in case of emergency might make it impossible to start.

- Any power failure, such as the burning out of electric supply cables during a fire, may render the elevators inoperative or might result in trapping persons in elevators stopped between floors. Under fire conditions there might not be time to permit rescue of trapped occupants through emergency escape hatches or doors.

In addition, there are other concerns. Fire or smoke might damage elevator equipment. Water from sprinklers or fire hoses could short out or cause other problems with electrical power and control wiring for the elevator. Overheating of elevator equipment could result in malfunction of elevators. Pressurization for smoke control could result in elevator doors jamming open, limiting movement of the car. Piston effect due to elevator car motion could pull smoke into the elevator lobby or the hoistway (elevator shaft). However, it is possible to design EEESs with a high level of protection relative to these concerns.

\footnotetext{
${ }^{2}$ This edition of the Life Safety Code was the last edition to list these "problems".
} 


\section{EEES Concept}

An EEES includes the elevator equipment, hoistway, machine room, and other equipment and controls needed for safe operation of the elevator during the evacuation process. Because people must be protected from fire and smoke while they wait for an elevator, the system must include protected elevator lobbies (figure 2). Such protected elevator lobbies also help to prevent the fire from activating elevator buttons so that elevator cars are prevented from being called by the fire to the fire floor ${ }^{3}$.

An EEES must have protection from heat, flame, smoke, water, overheating of elevator machine room equipment, and loss of electrical power. In addition, an EEES must have a control approach to assure protection of people traveling in the elevator. In areas of high seismic activity, attention must be paid to earthquake design. Further, the development of an EEES needs to take into account human behavior so that building occupants will be willing and capable to operate the system in an

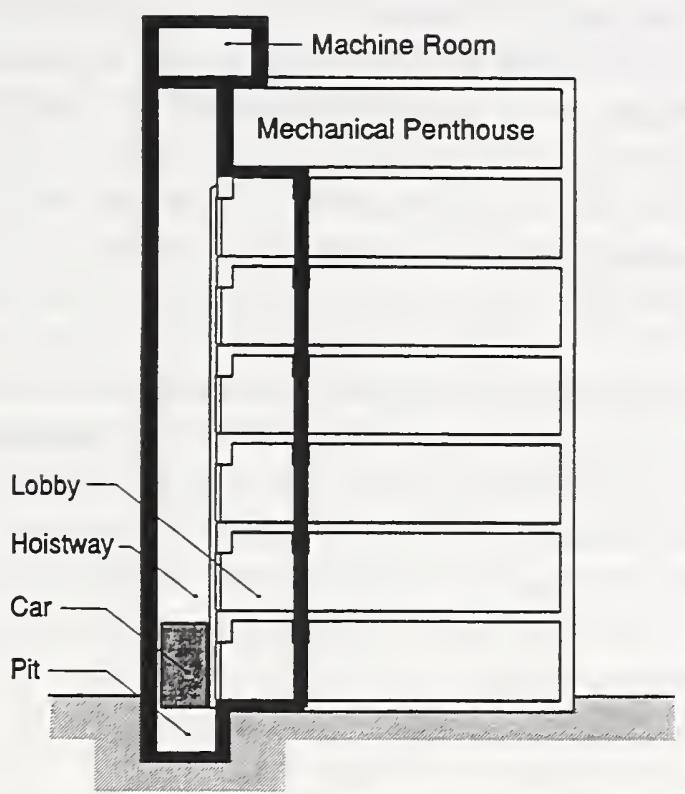

Figure 2.
Elevator system including elevator equipment, machine room, hoistway and elevator lobby emergency. The following sections address these issues.

The concern about people crowding into an elevator and doors not closing is significant only when there are enough people to form a crowd. As previously stated, this paper is concerned with EEESs for relatively small numbers of people. For the purposes of this paper, a small number of people is taken to be a number that will not result in crowding and doors forced open for the elevators being used. In most commercial buildings, the number of people with mobility limitations can be considered a small number. In ATCTs, the total number of occupants can also be considered a small number. For other applications, the normal methods of people movement (Pauls 1988, Nelson and MacLennan 1988) can be used to evaluate the potential for crowding.

\section{EEES Protection}

\subsection{Heat and Flame}

Compartmentation is one of the oldest methods of fire protection and has been extensively used to limit the spread of fire. Compartmentation is also one approach to smoke protection, and this is addressed in the next section. As a convenience to the reader the concepts of compartmentation are briefly described here, and for further information readers are referred to Barnett (1992), Boring, Spence and Wells (1981), Bushev et al. (1978) and Campbell (1991).

\footnotetext{
${ }^{3}$ Even buttons that are not heat sensitive can short out when subjected to the elevated temperatures of a fire.
} 
Buildings are divided into compartments formed by fire barriers. These barriers are walls, partitions and floor-ceiling assemblies that have a level of fire resistance. The traditional approach to evaluate fire resistance is to subject a section of a barrier to a standard fire in a standard furnace. Each building fire is unique in duration and temperature, and it is not surprising that the performance of barriers in building fires differs to some extent from the performance in standard tests. Historically, the goal of fire resistant construction was property protection, but the goals of current codes include life safety. The codes require specific levels of fire resistance for specific applications with the goal of protecting life.

Because the FAA (1988) references the NFPA 101 Life Safety Code (NFPA 1994) for design criteria, a brief overview of the NFPA 101 requirements concerning compartmentation follows. The NFPA 101 requires that fire barriers meet the requirements of NFPA 251 (1990) and have fire resistance ratings of 20 minute, $1 / 2$ hour, $3 / 4$ hour, 1 hour, or 2 hour. Door openings and other types of openings in these barriers need to be protected. Fuel loads may be located next to walls and partitions, but generally they are not located against doors. Thus it is expected in many fires that doors would have less severe exposures than the barriers in which they are located. In general, NFPA requires: a 20 minute door in a 20 minute barrier, a 20 minute door in a $1 / 2$ hour barrier, a 20 minute door in a $3 / 4$ hour barrier, a 1 hour door in a 1 hour barrier, and a $1 \frac{1 / 2}{2}$ hour door in a 2 hour barrier. However, there are some exceptions to these requirements depending on the building occupancy. In general, stairs connecting three stories or less are required to be separated from the rest of the building by 1 hour fire barriers, and stairs connecting four or more stories are required to be separated by 2 hour fire barriers. The requirement for other shafts including hoistways in new construction is the same.

For an EEES to be equivalent to stairs with respect to compartmentation, the enclosures of the EEES must be at least as good as that of a stairs. The enclosures of the hoistway, elevator lobbies and machine room need to have the same level of fire resistive construction as stairwells. To be equivalent with NFPA 101 compartmentation requirements, an EEES four stories or taller would need 2 hour barriers separating the hoistway, elevator lobbies and machine room from the rest of the building.

\subsection{Smoke}

The mechanisms that can be used to provide smoke protection are air flow, buoyancy, compartmentation, dilution and pressurization. Detailed information about these mechanisms is presented by Klote and Milke (1992). Because of the concern about supplying oxygen to the fire as discussed by Klote and Milke, air flow is not recommended for smoke protection of EEESs. Buoyancy is primarily used to manage smoke in large spaces such as atria and shopping malls. Systems that rely on buoyancy are inappropriate for smoke protection of EEESs.

\subsubsection{Compartmentation}

Systems using only compartmentation have a long history of providing protection against fire spread. In such fire compartmentation, the walls, partitions, floors, doors, and other barriers provide some level of smoke protection to spaces remote from the fire. Smoke leakage into spaces protected by compartmentation depends on the leakage of barriers and pressure differences due both to natural building flows and fire induced flows. Analysis of smoke protection by compartmentation is possible and requires analysis of smoke leakage, toxicity and evacuation. Bukowski et al. (1991) provide computer routines 
for such evaluations. While such methods can be used to design these systems, no testing technique has been developed that can assure that these systems will work as intended. However, an approach similar to smokeproof enclosures for stairs by natural ventilation is possible as discussed later.

\subsubsection{Dilution}

Dilution of smoke is sometimes referred to as smoke purging, smoke removal, smoke exhaust, or smoke extraction. Dilution consists of supplying and exhausting air from a compartmented space. For a compartment remote from the fire, dilution can be used to maintain tenable conditions when there is some smoke infiltration from an adjacent space. As with compartmentation, analysis of smoke protection by dilution is possible and requires analysis of smoke leakage, toxicity and evacuation. Also the computer routines of Bukowski et al. can be used for such evaluations. As with compartmentation, no testing technique has been developed that can assure that these systems will work as intended.

\subsubsection{Pressurization}

Systems relying on compartmentation with pressurization are designed on the basis of no smoke leakage into protected spaces. Accordingly, analysis of such pressurization systems is less complex than that of systems using compartmentation alone or compartmentation with dilution. Acceptance testing and routine testing of pressurization systems is done by measurement of the pressure difference produced when the system is operating. Such testing provides a level of assurance about system performance during a fire. For systems that have windows breaking, windows opening, or doors opening to the outside; smoke control systems by pressurization as discussed later can maintain pressurization during such pressure fluctuations. Considering the potential for windows to break during unsprinklered fires, pressurization systems are recommended for smoke protection of EEESs in unsprinklered buildings.

\subsubsection{Joint U.S./Canadian Research}

A joint U.S./Canadian project was undertaken to evaluate the feasibility of using pressurization for smoke protection of elevators used for fire evacuation. Full-scale fire experiments were conducted in a ten-story fire research tower near Ottawa (Tamura and Klote 1988, 1987a, 1987b). These experiments verified that pressurization can provide smoke protection for the EEES. Additionally, the project addressed the impact of pressure disturbances caused by elevator car motion on smoke control (Klote and Tamura 1987, 1986a; Klote, 1988). As already stated, such piston effect is a concern, because it can pull smoke into a normally pressurized elevator lobby.

This section summarizes the main concepts about smoke control for elevators developed from the joint project. For detailed design information concerning these systems, readers are referred to Klote and Milke (1992) for general information concerning smoke control, Klote and Tamura (1991) for specific information about elevator smoke control not including wind effects, and Klote (1993) 


\subsubsection{Elevator Doors Jamming}

Elevator doors jam open when the force of the door mechanism is insufficient to overcome the force of friction. The friction force increases with the pressure difference from the hoistway to the lobby. In tall buildings, elevator doors frequently jam open during extremely cold weather. This is caused by stack effect induced pressure differences. Elevator mechanics commonly adjust the door closing forces to prevent door jamming. During elevator smoke control operation, the possibility of door jamming may decrease or increase. If the leakage area of the elevator lobby doors is less than that of the elevator doors, the pressure difference across the elevator doors can be less than that normally occurring. In field tests conducted by Klote (1984), no door jamming was encountered at pressure differences as high as 75 $\mathrm{Pa}\left(0.3\right.$ in $\left.\mathrm{H}_{2} \mathrm{O}\right)$. When door jamming was encountered in an elevator without smoke control, it was found that only a small additional force applied by the palms of the hands was sufficient to overcome jamming. Fire fighters can be taught to overcome door jamming this way, and elevator doors could be fitted with grips or handles to aid in this effort.

\subsubsection{Elevator Piston Effect}

Analysis of the airflows and pressures produced by elevator car motion in a pressurized hoistway was developed by Klote (1988) based on the continuity equation for the contracting control volume in a hoistway above an ascending car. From this analysis, an expression was developed for the critical pressure difference from the elevator lobby to the building at which piston effect cannot overcome lobby pressurization:

$$
\Delta p_{c r i t}=\frac{\rho_{s} K_{c p}}{2}\left(\frac{A_{e} A_{s} V}{A_{r i} A_{a} C_{c}}\right)^{2}
$$

where

$\Delta p_{\text {crit }}=$ critical pressure difference, $\mathrm{Pa}\left(\right.$ in $\left.\mathrm{H}^{2} \mathrm{O}\right)$

$\rho_{s} \quad=$ air density in hoistway, $\mathrm{kg} / \mathrm{m}^{3}\left(\mathrm{lb} / \mathrm{ft}^{3}\right)$

$A_{s} \quad=$ cross-sectional area of the hoistway, $\mathrm{m}^{2}\left(\mathrm{ft}^{2}\right)$

$A_{r i} \quad=$ leakage area between the lobby and the building, $\mathrm{m}^{2}\left(\mathrm{ft}^{2}\right)$

$A_{a} \quad=$ free area around the elevator car, $\mathrm{m}^{2}\left(\mathrm{ft}^{2}\right)$

$A_{e} \quad=$ effective area between the hoistway and the outside, $\mathrm{m}^{2}\left(\mathrm{ft}^{2}\right)$

$V \quad=$ elevator car velocity, $\mathrm{m} / \mathrm{s}(\mathrm{ft} / \mathrm{min})$

$C_{c} \quad=$ flow coefficient for flow around car, dimensionless

$K_{c p} \quad=$ coefficient, $1.00(1.66 \times 10-6)$

The flow coefficient, $C_{c}$, was determined experimentally (Klote and Tamura 1986b) at about 0.94 for a multiple car hoistway and 0.83 for a single-car hoistway.

The effective area of a system of flow areas is the area that results in the same flow as the system when it is subjected to the same pressure difference over the total system of flow paths. For further information about effective flow areas the reader is referred to Klote and Milke (1992). In this application, the system of leakage areas consists of the areas between the hoistway and the lobby, between 
the lobby and the building, and between the building and the outside. The effective area between the hoistway and the outside is

$$
A_{e}=\left(\frac{1}{A_{s r}^{2}}+\frac{1}{A_{r i}^{2}}+\frac{1}{A_{i o}^{2}}\right)^{-\frac{1}{2}}
$$

where

$A_{s r}=$ leakage area between the hoistway and the lobby, $\mathrm{m}^{2}\left(\mathrm{ft}^{2}\right)$

$A_{\text {io }}=$ leakage area between the building and the outside, $\mathrm{m}^{2}\left(\mathrm{ft}^{2}\right)$

Equations (1) and (2) can be used to design an elevator pressurization system that piston effect cannot overcome.

\subsubsection{Pressure Fluctuations}

Elevator smoke control systems must be designed to maintain design pressure differences under the likely conditions of opened and closed doors and windows and of broken windows. During fires in unsprinklered buildings, there is a high probability of window breakage due to the fire. Klote and Tamura (1986b) showed that opening a large flow path from the pressurized spaces to the outside can result in a significant loss in pressurization. For example, opening the elevator doors, elevator lobby doors, and exterior doors resulted in a pressure drop from $32 \mathrm{~Pa}(0.13$ in $\mathrm{H} 2 \mathrm{O})$ to $7 \mathrm{~Pa}(0.03$ in $\mathrm{H} 2 \mathrm{O})$ for a system without features to resist pressure fluctuation.

Elevator smoke control is based on the following conditions concerning pressure fluctuations:

1. Some exterior building doors will be propped open by the fire service.

2. Stairwell doors will open and close as people use the stairs.

3. Elevator doors will open and close as people use the elevators.

4. Some windows may break due to the fire or the action of occupants or the fire service.

5. Lobby doors (between the elevator lobby and the building) will be the type that automatically close upon detection of smoke.

6. Some lobby doors will be blocked or not working properly, and they will not close automatically.

7. Occupants will close lobby doors to prevent being exposed to smoke.

8. Occupants not exposed to smoke may not close lobby doors that are blocked open or fail to close properly.

The design of an elevator pressurization system should be such that it will function under the pressure fluctuations resulting from doors opening, doors closing and windows breaking. Further, the smoke control system should be designed for some of the lobby doors open on floors away from the fire. The 
system needs to be designed to maintain pressurization across the closed lobby doors on the fire floor when some elevator lobby doors are open on floors away from the fire. As already stated, occupants will close lobby doors to prevent being exposed to smoke. Further, if an occupant opens a door for a few

seconds to enter the lobby, conditions in the building near the lobby could not be untenable or the occupant would not have been able to reach the lobby. Leakage of small amounts of such smoke into the lobby as an occupant enters cannot result in untenable conditions in the lobby.

\subsubsection{Smoke Control Systems}

Elevator smoke control systems can incorporate features to deal with pressure fluctuations discussed above. These features include pressure-relief vents, vents with barometric dampers, variable-supply air fans, fire floor venting, and fire floor exhaust.

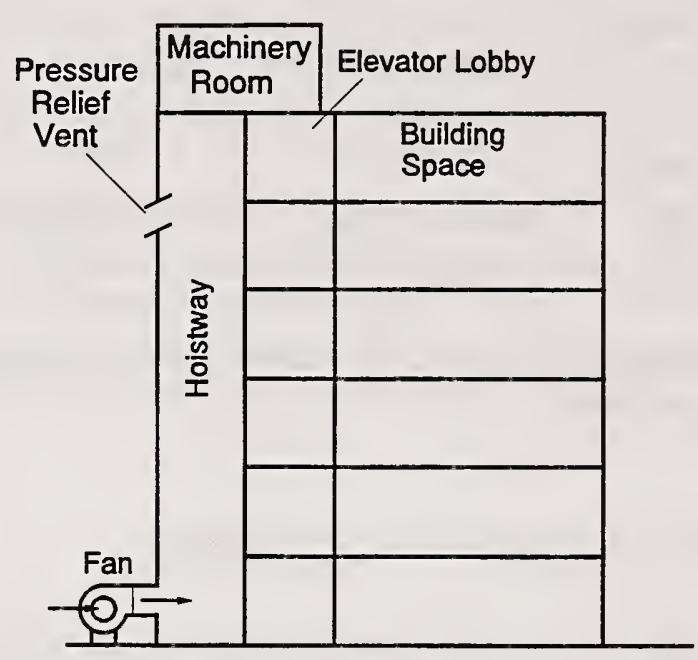

Figure 3. Elevator smoke control with a pressure relief vent

\section{Pressure-Relief Vent System}

This system has a "constant-supply" air rate fan and a pressure-relief vent to the outside as illustrated in Figure 3. The area of this vent is fixed and is sized for operation in the smoke control system. The vent can be fitted with automatic dampers, if it is desired for it to be normally closed. The supply rate varies to some extent with the pressure across the fan, but the term "constant-supply" is used to differentiate this fan from one that has a "variable-supply" rate. The vent must be large enough that the maximum allowable pressure difference is not exceeded when all doors are closed. When paths to the outside are opened, air flows through them and the hoistway pressure drops. This system must maintain at least the minimum allowable pressure difference when some design combination of paths is open.

\section{Barometric Damper System}

This system is similar to the one above, except that the vent has a barometric damper that closes when the pressure drops below a specified value. The use of these dampers minimizes air losses when paths from the hoistway are opened, and the pressurization fan can be sized smaller than for the above system. A normally closed automatic damper in front of (or after) the barometric damper can prevent damper chatter caused by the wind.

\section{Variable-Supply Air System}

Variable-supply air can be achieved by using one of many fans commercially available for a variableflow rate. Alternatively, a fan bypass arrangement of ducts and dampers can be used to vary the flow rate of supply air to the hoistway. The variable-flow fans are controlled by one or more static pressure sensors that sense the pressure difference between the lobby and the building. There are two approaches 
for use of the sensors. The airflow rate can be controlled by the average of signals from the sensors on all floors or it can be controlled by the signal from the fire floor.

Using the average of all the signals has the advantage that no information is required about where the fire is located. Using the fire floor sensor signal requires information about the fire location. This information can come from smoke detectors, heat detectors, or sprinkler water flow indicators. Using the fire floor signal has the advantage that the system maintains a set pressure difference at this most critical location.

System with Fire Floor Venting or Exhaust

Smoke venting and smoke exhaust of the fire floor can improve system performance. The venting or exhaust

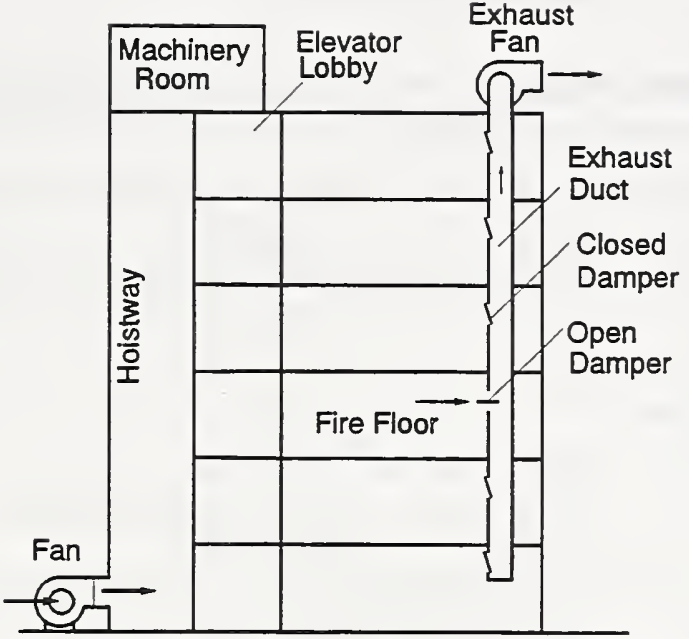

Figure 4. Elevator smoke control with fire floor exhaust increases the pressure difference from the lobby to the fire floor. The vents can be exterior wall vents or non-powered smoke shafts. Figure 4 shows a fan-duct system intended to exhaust the fire floor. Upon detection of fire or smoke, the damper opens on the fire floor and the exhaust fan is activated. The detection system must be configured to identify the fire floor.

\subsection{Water}

During a building fire water from sprinklers and fire hoses can damage electronic, electrical, and mechanical components of an EEES. For fires in the hoistway, elevator lobbies or machine room, the most appropriate action seems to be to take the elevators out of service. Fires in the hoistway or elevator lobbies can easily result in untenable conditions within the EEES. Further, an elevator cannot be expected to operate when there is a fire in the machine room, because of elevator equipment exposure to elevated temperatures. If there is a fire in the hoistway, elevator lobbies or machine room; the EEES should be shut down. Because of the limited fuel load, relatively small compartment size and the fire resistive construction, fires in the hoistway, elevator lobbies or machine room are not believed to have as high a potential for hazard as fires in many other building spaces. If evacuation is needed, other vertical paths (other elevators and stairs) can be used.

For fires outside the EEES, the two major locations of concern about water damage are the machine room and the hoistway. Two potential approaches to minimize water damage are:

1. use of elevator components that can function in a wet environment, and

2. prevention of water from entering the hoistway or machine room.

The following sections discuss these approaches including the extent of the water exposure that elevator emergency evacuation systems might face. 


\subsubsection{Water Exposure}

Water exposure can be from sprinklers or fire hoses. The flow through a sprinkler can be described by the orifice equation.

$$
Q=C A \sqrt{\frac{2 \Delta p}{\rho}}
$$

where

$Q=$ flow rate, $\mathrm{m}^{3} / \mathrm{s}\left(\mathrm{ft}^{3} / \mathrm{s}\right)$

$C=$ discharge coefficient, dimensionless

$A=$ orifice area, $\mathrm{m}^{2}\left(\mathrm{ft}^{2}\right)$

$\Delta p=$ pressure difference across the orifice, $\mathrm{Pa}\left(\mathrm{lbf} / \mathrm{ft}^{2}\right)$

$\rho \quad=$ density, $\mathrm{kg} / \mathrm{m}^{3}\left(\right.$ slug $\left./ \mathrm{ft}^{3}\right)$

This equation is be expressed for water in the units commonly used in fire protection community as

$$
Q=K_{w} C d^{2} \sqrt{\Delta p}
$$

$Q \quad=$ flow rate, $\mathrm{L} / \mathrm{min}(\mathrm{gpm})$

$C=$ discharge coefficient, dimensionless

$d \quad=$ orifice diameter, $\mathrm{mm}$ (in)

$\Delta p=$ pressure difference across the orifice, $\mathrm{kPa}(\mathrm{psi})$

$K_{w}=$ coefficient, $0.0667(29.8)$

For conversion factors between SI units and English units see appendix A. For a commonly manufactured sprinkler head with a $12.7 \mathrm{~mm}(0.50 \mathrm{in})$ diameter orifice, the flow rate at $69 \mathrm{~Pa}(10 \mathrm{psi})$ with a discharge coefficient of 0.75 is $67 \mathrm{~L} / \mathrm{min}(17.7 \mathrm{gpm})$. These conditions are typical of the kind of minimum requirements for the remote heads in a sprinkler system. However, heads closer to the source of water would be subject to higher pressures and have higher flows. For example, a pressure away from a the remote head of $600 \mathrm{kPa}(87 \mathrm{psi})$, the flow would be about $200 \mathrm{~L} / \mathrm{min}(53 \mathrm{gpm})$.

The extent of water exposure from fire hoses is usually different for interior and exterior attacks. For interior attacks, the fire service usually uses manually held hoses with either solid-stream nozzles or spray nozzles. Solid-steam nozzles of diameter from 6 to $29 \mathrm{~mm}(0.25$ to 1.125 in) are considered for hand held hoses. The flow through these nozzles can be described by equations (1) and (2). A $29 \mathrm{~mm}(1.125$ in) solid-steam nozzle produces the standard stream of $950 \mathrm{~L} / \mathrm{min}(250 \mathrm{gpm})$ at $310 \mathrm{kPa}(45 \mathrm{psi})$ nozzle pressure.

Spray nozzles (also called fog nozzles) from 19 to $64 \mathrm{~mm}$ ( 0.75 to $2.25 \mathrm{in}$ ) are also manually held and used for interior attacks. Manually held hose with solid-steam or spray nozzles have flow rates approximately from 40 to $1150 \mathrm{~L} / \mathrm{min}$ (11 to $300 \mathrm{gpm}$ ).

Often for exterior attacks, the fire service uses mechanically restrained hoses referred to as master flow devices that have flow rates from 1900 to $7500 \mathrm{~L} / \mathrm{min}$ (500 to $2000 \mathrm{gpm}$ ). The flows discussed above are summarized in table 1 . 
Table 1. Water flows of some suppression \& firefighting devices

\begin{tabular}{||lcc||}
\hline \hline Device & L/min & gpm \\
\hline \hline $12.7 \mathrm{~mm}$ (0.50 in) Sprinkler Head & $67-200$ & $17.7-53$ \\
$29 \mathrm{~mm}$ (1.125 in) Solid-Stream Hose Nozzle & 950 & 250 \\
Manually Held Hose with Spray Nozzle & $40-1150$ & $11-300$ \\
Master Flow Devices & $1900-7500$ & $500-2000$ \\
\hline
\end{tabular}

\subsubsection{Water Resistive Elevator Components}

Currently no elevators have been developed with water resistant components for operation during fire evacuations. However, many elevators operate outdoors on exterior walls of buildings with many of the system components exposed to rain, wind and extremes of temperature. These outdoor conditions are believed to be much more severe than those associated with water flow inside a hoistway due to a building fire. While it is technically feasible to build elevators with water protected components which will operate during a fire, testing and maintenance of such water resistive components is a concern.

Without routine testing for water resistance, components that degraded from years of use or were accidentally damaged would go undetected and unrepaired. To assure that the water resistive features operate properly, routine inspection, testing and repair efforts would be needed. The most positive approach to testing would involve use of a water spray or a water stream inside the hoistway and possibly inside the machine room. For machine rooms located at the bottom of the hoistway, the water problem is more of a concern. These water tests have the potential for water leakage to other building spaces and resulting damage to building finishes and other objects. Because little is known about water flow in hoistways, the extent to which water protection is needed and routine tests are needed is unknown.

The New York City Fire Department (NYCFD) and the ASME A17.1 Emergency Operations Committee are developing a test program to evaluate the effects of water entering elevator hoistways. The goal of this program is to evaluate the reliability of elevator operation by firefighters under conditions encountered during a fire. While not yet funded, such an effort is needed as a first step to evaluate the extent of the water issue. This joint NYCFD/ASME project is aimed at firefighters applications, but the results will also have application to elevator evacuation.

Further research may result in improved understanding of hoistway water flow, methods of developing water resistant elevator components and appropriate tests. Until such water resistance technology is developed for elevator evacuation, the only practical approaches are (1) prevention of water from entering the hoistway, (2) the use of exterior elevators, and (3) the use elevators with exterior lobbies. Theses alternatives are discussed below. 


\subsubsection{Prevention of Water Entry}

Building construction can be used with the intent of preventing water from entering the hoistway and machine room. The following sections discuss the use of sloping floors, floor drains and doors with seals to keep water out of the hoistway, and a possible approach combining these elements is discussed.

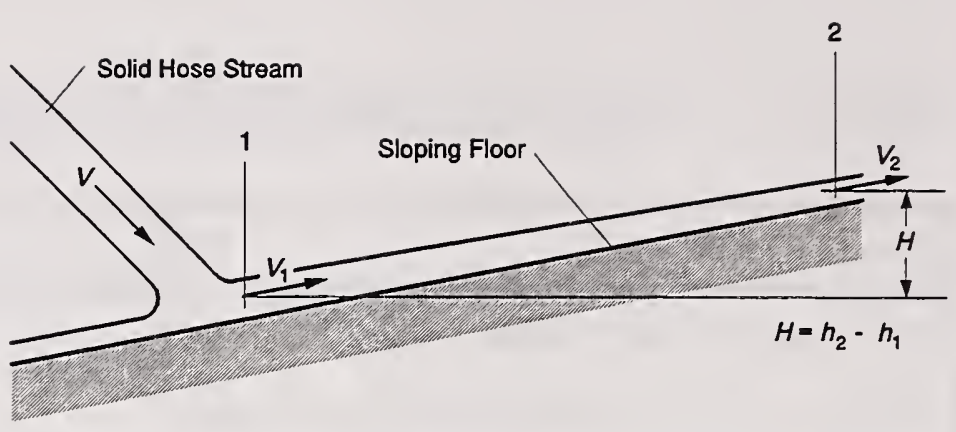

Figure 5. Solid hose stream striking sloping floor

\subsubsection{Sloping Floors}

Sloping floors can control water flow, provided that the water velocity is relatively low as when the flow is due to a distant spill [order of $0.1 \mathrm{~m} / \mathrm{s}(20 \mathrm{fpm})$ ]. The analysis of this section shows that a slopping floor cannot control relatively high velocity flow, such as those from hose streams. Consider a solid hose stream hitting a sloping floor as illustrated in figure 5. The water flow at a sloping floor can be described by the Bernoulli equation:

$$
\frac{V_{1}^{2}}{2}+\frac{p_{1}}{\rho_{1}}+g h_{1}=\frac{V_{2}^{2}}{2}+\frac{p_{2}}{\rho_{2}}+g h_{2}
$$

where

$V_{1}=$ velocity at location $1, \mathrm{~m} / \mathrm{s}(\mathrm{ft} / \mathrm{s})$

$p_{1}=$ pressure at location $1, \mathrm{~Pa}\left(\mathrm{lb} / \mathrm{ft}^{2}\right)$

$h_{1}=$ elevation at location $1, \mathrm{~m}(\mathrm{ft})$

$\rho_{1}=$ density at location $1, \mathrm{~kg} / \mathrm{m}^{3}\left(\operatorname{slug} / \mathrm{ft}^{3}\right)$

$V_{2}=$ velocity at location $2, \mathrm{~m} / \mathrm{s}(\mathrm{ft} / \mathrm{s})$

$p_{2}=$ pressure at location $2, \mathrm{~Pa}\left(\mathrm{lb} / \mathrm{ft}^{2}\right)$

$h_{2}=$ elevation at location $2, \mathrm{~m}(\mathrm{ft})$

$\rho_{2}=$ density at location $2, \mathrm{~kg} / \mathrm{m}^{3}\left(\operatorname{slug} / \mathrm{ft}^{3}\right)$

$g=$ acceleration of gravity, approximately $9.8 \mathrm{~m} / \mathrm{s}^{2}\left(32.2 \mathrm{ft} / \mathrm{s}^{2}\right)$

In figure 5 , location 1 is just after the hose stream strikes the floor, and $l o$ ion 2 is the height on the floor where the water velocity is zero. For frictionless flow, the velocity at 1 equals the hose stream velocity. For these condition:

$$
V=V_{1} ; \quad V_{2}=0 ; \rho=\rho_{1}=\rho_{2} ; \quad h_{1}=0 ; \quad H=h_{2} ; \quad p_{1}=p_{2} .
$$

Equation (3) becomes

$$
H=\frac{V^{2}}{2 g}
$$

which can be expressed as

where 


$$
H=K_{v} V^{2}
$$

$H \quad=$ height that water rises up the slope, $\mathrm{m}(\mathrm{ft})$

$V \quad=$ hose stream velocity, $\mathrm{m} / \mathrm{s}(\mathrm{ft} / \mathrm{s})$

$K_{v}=$ coefficient, $0.051(0.0156)$

For the standard stream from a $29 \mathrm{~mm}(1.125 \mathrm{in})$ solid-steam nozzle, the velocity is about $25 \mathrm{~m} / \mathrm{s}(82$

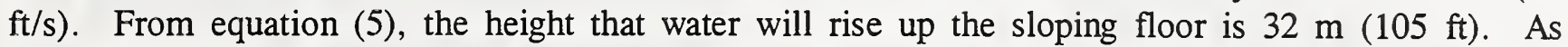
expected this shows that sloping floors can not be used to control flows from fire hoses. For a velocity of $0.1 \mathrm{~m} / \mathrm{s}(0.03 \mathrm{ft} / \mathrm{s})$, equation (5) indicates that water will go up about $0.5 \mathrm{~mm}(0.02 \mathrm{in})$. Thus sloping floors can control water from distant flows.

\subsubsection{Floor Drains}

A $50 \mathrm{~mm}$ ( $2 \mathrm{in})$ diameter floor drain has a maximum capacity of about $115 \mathrm{~L} / \mathrm{min}$ (30 gpm), and a 75 $\mathrm{mm}$ (3 in) diameter floor drain has a maximum capacity of about $190 \mathrm{~L} / \mathrm{min}(50 \mathrm{gpm})$. These capacities are for floor drains that are clean and have a slope of about $2 \%$ of the length. However, drains are sometime installed with less slope and they often become clogged.

By comparison with the water flows of sprinklers and fire hoses (table 1), it is apparent that a clean and properly installed floor drain of $75 \mathrm{~mm}$ ( 3 in) diameter may be able to carry away the water from sprinklers, but it does not have the capacity to deal with fire hose flows. A clogged drain or one without the proper slope my not be able to carry away the water from sprinklers.

Floor drains may be a significant part of a design to prevent water from entering a hoistway or machine room. However, it is not appropriate to rely totally floor drains for water protection.

\subsubsection{Flow Under Doors}

Gasketing and seals have been historically been used on exterior doors for comfort and energy conservation and on interior doors for control of odors, sound and light. Tight fitting elevator lobby doors are important for the performance of the elevator smoke control system. Tight fitting doors can reduce water flow into the elevator lobby. This section presents an analysis of water flow under doors that may be useful in determining the effect of door undercuts with and without seals or gaskets. Further, calculations are presented that illustrate how much water can flow through an undercut and why gasketing or seals are important.

When tightness is not important, it is common to have undercuts of 13 to $20 \mathrm{~mm}$ ( 0.5 to $.75 \mathrm{in})$. When efforts are made to seal a door, the crack at the bottom can be as small as $0.5 \mathrm{~mm}(0.002 \mathrm{in})$. The flow through an opening can be expressed by a general function:

$$
Q=f(\Delta p)
$$

The orifice equation [equation (3)] is an example of a flow function commonly used for turbulent flow. However, the flow through gaps around doors can be laminar, turbulent or in transition between these 
flow types. In general, the function $f$ depends on the geometry of the opening and the Reynolds number. The Reynolds number is

$$
R_{e}=\frac{D_{h} V}{v}
$$

where

$R_{e} \quad=$ Reynolds number, dimensionless

$D_{h}=$ hydraulic diameter of flow path, $\mathrm{m}$

(ft)

$V=$ average velocity in flow path, $\mathrm{m} / \mathrm{s}$

$(\mathrm{ft} / \mathrm{s})$

$\nu \quad=$ kinematic viscosity, $\mathrm{m}^{2} / \mathrm{s}\left(\mathrm{ft}^{2} / \mathrm{s}\right)$

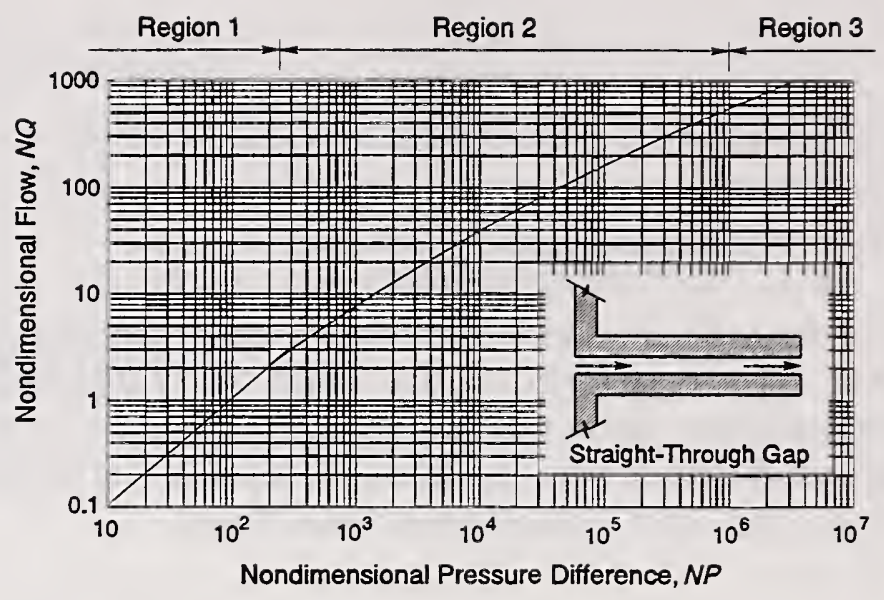

Figure 6. Relationship between flow and pressure

Gross and Haberman (1988) developed a difference for straight-through crack generalized approach to determine the leakage through gaps around doors based on experimental data from air flow through such openings. This approach can be used to obtain a estimate for water. Gross and Haberman developed functional relationships between the following nondimensional groups:

$$
N Q=\operatorname{Re}\left(\frac{a}{x}\right)
$$

and

$$
N P=\frac{\Delta p D_{h}^{2}}{\rho v^{2}}\left(\frac{D_{h}}{x}\right)^{2}
$$

where

$N Q=$ dimensionless flow rate

$N P=$ dimensionless pressure difference

$R_{e}=$ Reynolds number, dimensionless

$a=$ thickness of gap in direction perpendicular to flow, $\mathrm{m}(\mathrm{ft})$

$x=$ depth of gap in flow direction, $\mathrm{m}(\mathrm{ft})$

$\Delta p=$ pressure difference across gap, $\mathrm{Pa}\left(\mathrm{lb} / \mathrm{ft}^{2}\right)$

$D_{h}=$ hydraulic diameter; $D_{h}=2 a, \mathrm{~m}(\mathrm{ft})$

$\rho=$ density of fluid in gap, $\mathrm{kg} / \mathrm{m}^{3}\left(\mathrm{slug} / \mathrm{ft}^{3}\right)$

$\nu=$ kinematic viscosity, $\mathrm{m}^{2} / \mathrm{s}\left(\mathrm{ft}^{2} / \mathrm{s}\right)$

Gross and Haberman used an analytical method of Miller and Han (1971) to account for the pressure losses in the entrance region before fully developed flow is achieved in a straight-through slot. Their relation for flow versus pressure difference is shown in figure 6 . Three regions of flow through the straight-through slot were identified, and equations for these regions are:

Region 1 (Viscous dominated region - for $N P \leq 250$ ): 


$$
N Q=0.01042 N P
$$

Region 2 (Transition region - for $\left.250<N P<10^{6}\right)$ :

$$
N Q=0.016984 N P^{\alpha}
$$

where $\alpha=1.01746-.044181 \log _{10}(N P)$

Region 3 (Kinetic dominated region - for $N P \geq 10^{6}$ ):

$$
N Q=0.555 N P^{1 / 2}
$$

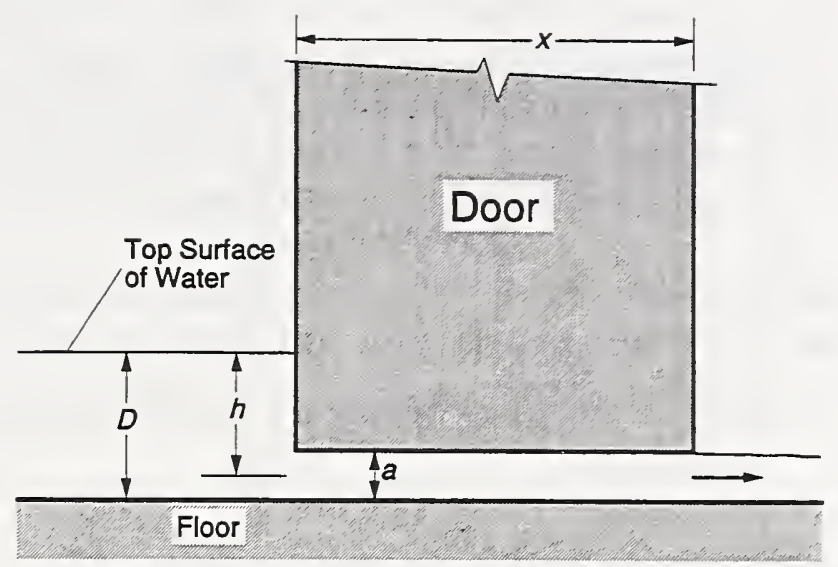

Figure 7.
Flow under door exposed to standing water

The equations for regions 1 and 3 were developed by Gross and Haberman, and the exponents are as expected considering that region 1 is dominated by viscous forces and region 3 is dominated by kinetic forces. Region 2 is a transition between the other two regions. Gross and Haberman's analysis for region 2 is complicated, and equation (11) is an approximation to the Gross and Haberman analysis developed by Forney (1989). Forney's approximation is within $6 \%$ of the more complicated analysis. Forney's approximation has the advantage that at the end points it is continuous with the expressions for the other two regions. This is particularly attractive for computer applications. The volumetric flow rate through a straight-through slot is

$$
Q=\frac{v \times L N Q}{D_{h}}
$$

where

$Q=$ volumetric flow rate, $\mathrm{m}^{3} / \mathrm{s}\left(\mathrm{ft}^{3} / \mathrm{s}\right)$

$N Q=$ nondimensional flow

$x=$ depth of gap in flow direction, $\mathrm{m}(\mathrm{ft})$

$D_{h}=$ hydraulic diameter; $D_{h}=2 a, \mathrm{~m}(\mathrm{ft})$

$L=$ length of gap, $\mathrm{m}(\mathrm{ft})$

$\nu=$ kinematic viscosity, $\mathrm{m}^{2} / \mathrm{s}\left(\mathrm{ft}^{2} / \mathrm{s}\right)$

Figure 7 illustrates water flow for a door exposed to standing water. This analysis is based on the simplifying assumption that the pressure across the path of the door undercut is approximately equal to the hydrostatic pressure difference from the midpoint of the undercut gap to the top surface of the water. This can be expressed as

$$
\Delta p=\rho g h=\rho g\left(D-\frac{a}{2}\right)
$$

where 
$\Delta p=$ pressure difference across undercut, $\mathrm{Pa}\left(\mathrm{lb} / \mathrm{ft}^{2}\right)$

$\rho \quad=$ density of water in the gap, $\mathrm{kg} / \mathrm{m}^{3}\left(\mathrm{slug} / \mathrm{ft}^{3}\right)$

$g \quad=$ acceleration of gravity, $\mathrm{m} / \mathrm{s}^{2}\left(\mathrm{ft} / \mathrm{s}^{2}\right)$

$D=$ distance from floor to the top surface of the water, $\mathrm{m}(\mathrm{ft})$

$a \quad=$ thickness of gap in direction perpendicular to flow, $\mathrm{m}(\mathrm{ft})$

Example: How much water flows through an undercut of $6 \mathrm{~mm}(0.24 \mathrm{in})$, if it is exposed to standing water $13 \mathrm{~mm}$ (0.51 in) deep? The parameters are:

$$
\begin{aligned}
& a=.006 \mathrm{~m}(0.0197 \mathrm{ft}) \quad x=0.038 \mathrm{~m}(0.125 \mathrm{ft}) \\
& L=0.914 \mathrm{~m}(3 \mathrm{ft}) \quad D=.013 \mathrm{~m}(0.0427 \mathrm{ft}) \\
& g=9.8 \mathrm{~m} / \mathrm{s}^{2}\left(32.2 \mathrm{ft} / \mathrm{s}^{2}\right) \quad \rho=1000 \mathrm{~kg} / \mathrm{m}^{3}\left(1.94 \mathrm{slug} / \mathrm{ft}^{3}\right) \\
& \nu=1.006 \times 10^{-6} \mathrm{~m}^{2} / \mathrm{s}\left(1.083 \times 10^{-5} \mathrm{ft}^{2} / \mathrm{s}\right)
\end{aligned}
$$

From equation (14), $\Delta p=98 \mathrm{~Pa}$ or $2.05 \mathrm{lb} / \mathrm{ft}^{2}\left(0.39\right.$ in $\left.\mathrm{H}_{2} \mathrm{O}\right)$.

From equation (9), $N P=1,390,000$.

From equation (12), $N Q=6540$.

From equation (13), $Q=0.0019 \mathrm{~m}^{3} / \mathrm{s}$ or $114 \mathrm{~L} / \mathrm{min}$ (30 gpm).

Figure 8 shows the water flow for this example with different size gaps under the door. For a door that is sealed, the gap might be considered about $2 \mathrm{~mm}$ (0.08 in) thick, and the resulting flow would be about $30 \mathrm{~L} / \mathrm{min}(8$ $\mathrm{gpm})$. For a door with a gap of $12 \mathrm{~mm}(0.47 \mathrm{in})$, the flow would be about $190 \mathrm{~L} / \mathrm{min}$ (50 gpm).

One approach to water, that has flowed under a door into an elevator lobby, is to carry it away by means of a floor drain. It can be seen from the earlier discussion of floor drains, that a clean and properly installed floor drain of $75 \mathrm{~mm}$ ( 3 in) diameter may be able to carry away the

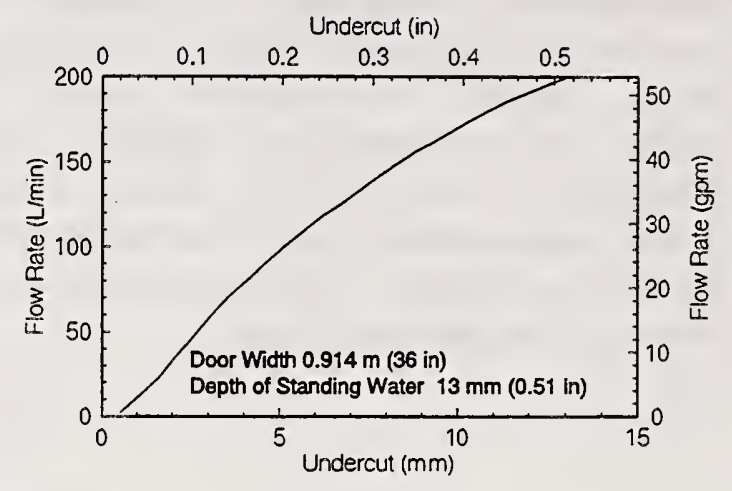

Figure 8. Calculated flow under door exposed to standing water water flowing under a door with $12 \mathrm{~mm}$ (.47 in) undercut.

However, a clogged drain or one without the proper slope my not be able to carry away the water flowing under such a door. Thus door seals are needed to reduce the water flow under doors to a level that can be accommodated by floor drains.

\subsubsection{Possible Approach}

The combined use of sloping floors, floor drains and doors with seals to prevent water flow into the hoistway is illustrated in figure 9. The lobby door with seals reduces the extent that water can get inside the lobby. The floor drain is located on the inside of the lobby, which reduces the amount of water that can reach the drain. If the drain were outside the lobby, the water flow could exceed the capacity of the drain. The lobby door must be opened when people enter the lobby. The floor drain and the sloped floor are intended to deal with the small quantities of water that may enter the lobby when the door is opened. If small streams of water flow past the floor drain, the sloping floor ices the chance of water reaching the hoistway. A trench drain (figure 10) can help minimize flow past the drain. In the idealized 
arrangement of figure 9, the elevator doors are at a right angle to the lobby door reducing the potential that water spray into the lobby through an open doorway will reach the hoistway.

The above discussion addressed preventing water flow through the elevator lobby, but water can also flow directly into the hoistway. Efforts should be made to prevent water flow directly into the hoistway. Cracks and gaps on the inside surface of the hoistway should be filled and sealed, and a water resistant coating on the surface may be appropriate.

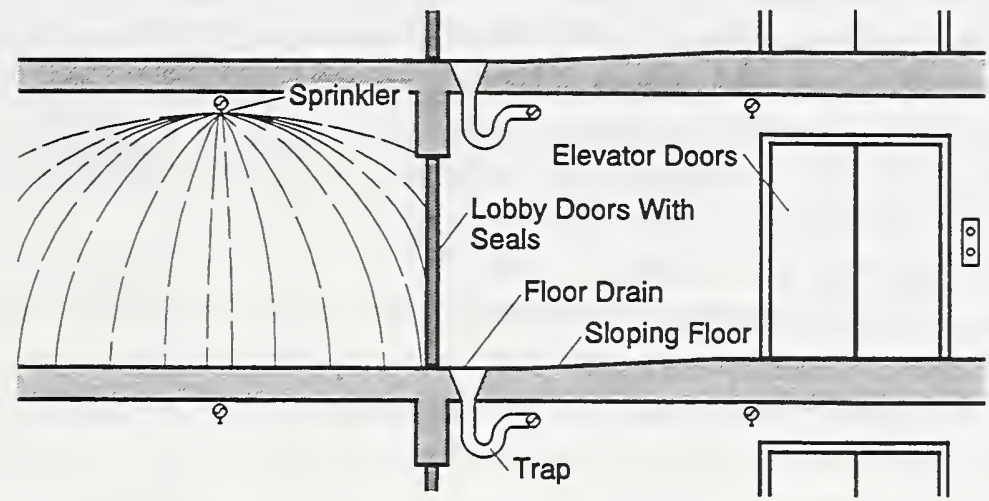

Figure 9. Conceptual use of sloping floors, floor drains and doors with seals in an effort to prevent water flow into hoistway

\subsubsection{Exterior Elevators}

The discussion so far was restricted to elevators located inside a building. However, there are advantages to locating elevators on the outside of the building. As already stated, many elevators operate outdoors on exterior walls of buildings with many of the system components exposed to rain, wind and extremes of temperature. Such exterior elevators could be used as

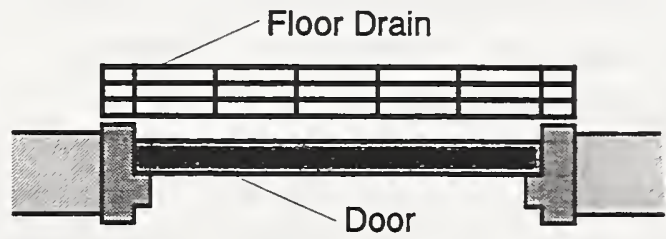

Figure 10. Use of trench floor drain to minimize water flow past drain EEESs. Exterior elevators are subjected to severe rain and winds. However, it is possible that the water flow through an elevator door into the hoistway would be significantly different from flow due to rain, and elevator components that work during rain might fail due to water exposure during a fire. At present, it is recommended that exterior elevators not be used as part of an EEES without protecting the elevator lobby from water entry. Research is needed to study the nature of water flow in hoistways.

\subsubsection{Smokeproof Enclosures by Natural Ventilation}

Some elevators are located in their own towers and are separated from the building by a section of exterior walkway or an exterior elevator lobby. This approach is used in many motels in warm climates, and it is illustrated in figure 11 (a). Such elevators are another alternative for EEESs.

The water flow due to sprinklers and fire hoses in the building that was not stopped by closed doors with seals would flow into the elevator lobby. This lobby is outside and is designed for water to flow away from the elevator doors. The approach that protects the elevator from rain can be expected to protect it from water during a fire.

Further, such elevator lobbies being open to the outside are similar to an approach for stairs described in the NFPA Life Safety Code as smokproof enclosures by natural ventilation. To qualify as naturally 
ventilated, the code requires that a stair vestibule have a minimum net area of $1.5 \mathrm{~m}^{2}\left(16 \mathrm{ft}^{2}\right)$ of opening in an exterior wall facing an exterior court, yard, or public space at least $6.1 \mathrm{~m}(20 \mathrm{ft})$ in width. The idea of this opening is to provide a path for smoke flow from the building to flow outside without going into the stairs. This same approach can be done with elevators. Further, an exterior elevator that is separated from the building as shown in figure 11(b) would also have a similar level of water and smoke protection.

\subsection{Overheating of Elevator Machine Room Equipment}

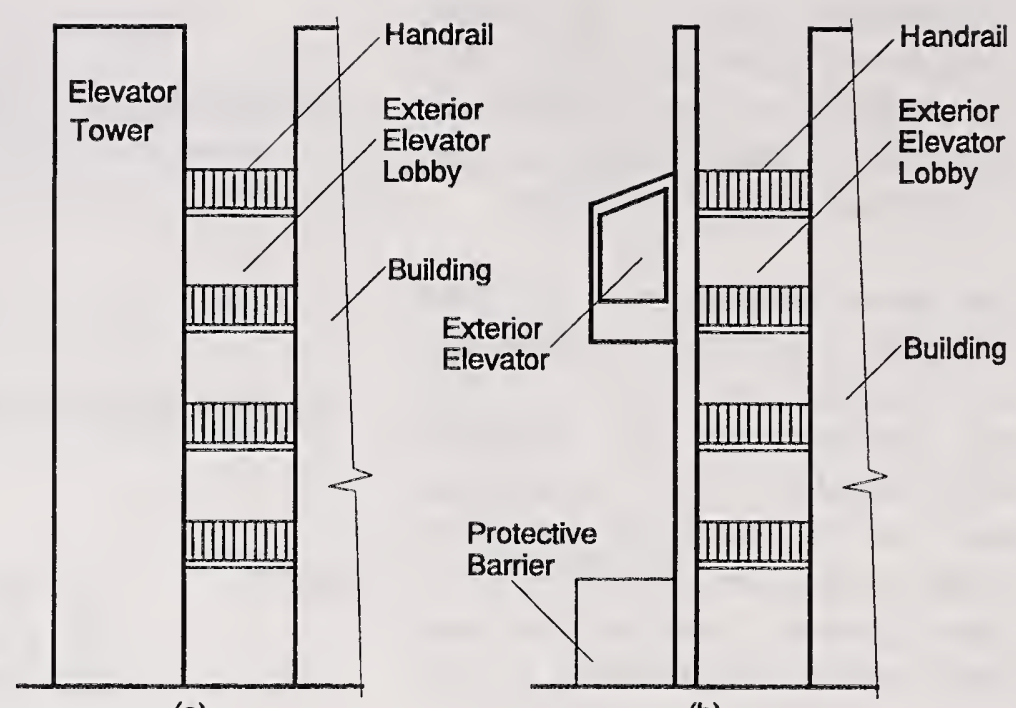

(b)

Figure 11. Elevators with exterior lobby: (a) elevator in tower separated from building, and (b) exterior elevator separated from building.

Loss of cooling can result in loss of elevator service due to overheating of elevator equipment, and precautions need to be taken to minimize the likelihood of such overheating. The elevator controllers located in the machine room are of particular concern because of the high heat generation rates of their solid state components. Most elevator manufacturers specify a maximum machine room temperature in which their controllers can operate. This temperature is usually in the range of 30 to $35^{\circ} \mathrm{C}\left(86\right.$ to $\left.95^{\circ} \mathrm{F}\right)$. Temperatures in excess of those specified by the manufacturers can reduce elevator reliability or result in elevator malfunction. These malfunctions include cars traveling with open doors and cars going to floors that were not called. The ASME A17 Committee is developing requirements to prevent elevator operation with overheated controllers. For further information about the operation of elevators at high temperatures readers are referred to Ribiberio (1991), Marchitto (1991) and Madison (1991).

Elevators intended to be used for emergency evacuation must have a reliable means of cooling machine room equipment during the conditions that are likely during a fire. For fires inside the EEES (machine room, hoistway and elevator lobby), the elevator system should be shut down, and cooling of machine room equipment is not needed. Unless otherwise stated, the discussion that follows is only concerned with building fires outside of the EEES. Three approaches to provide this cooling are:

1. air conditioning equipment dedicated to cooling the machine room,

2. air conditioning equipment for cooling the machine room and other building spaces,

3. equipment specifically developed for cooling the elevator controller, and

4. thermal storage for keeping the elevator controller cool during a fire elevator operation. 
Currently, machine room cooling is either supplied by dedicated air conditioning equipment or by equipment that also conditions other spaces. Thus approaches 1 and 2 have the advantage of using existing methods and equipment. The challenges with these approaches are to provide protection against fire damage and loss of electrical power. Reliability of electrical power is addressed in the next section, but the dedicated equipment uses less electricity which is an advantage from the viewpoint of reliable power.

Dedicated equipment located in the machine room or outside the building eliminates the possibility of damage to this equipment from fire outside the machine room to the extent that the fire resistive construction withstands the fire. Examples of such cooling equipment include: inexpensive through-thewall units, and roof mounted condenser units with fan and evaporator coils located in the machine room. Thus approach 1 has the advantage of lower probability of fire damage during elevator fire evacuation than approach 2.

Approach 3 has been informally discussed by some people interested in fire applications of elevators. The electronic industry has considerable experience with cooling electronic equipment using a variety of heat transfer fluids including air and water. However, this approach would require manufacturers to develop new controllers incorporating cooling capabilities. Approaches 1 and 2 have the advantage that they use components that are currently on the market.

Approach 4 consists of providing thermal storage for keeping the elevator controller cool during a fire elevator operation. The thermal storage could be in the form of a water reservoir or of a metallic heat sink. As with approach 3, the use of thermal storage would require manufacturers to develop new controllers.

In conclusion, approach 1 which is dedicated air conditioning equipment located in the machine room or outside of the building has the following advantages:

1. Approach 1 eliminates the possibility of damage to the machine room air conditioning equipment from fire outside the machine room to the extent that the fire resistive construction withstands the fire.

2. Approach 1 uses less electricity than approach 2 which is an advantage from the viewpoint of reliable power.

3. Approach 1 has the advantage of using components that are currently on the market.

\subsection{Loss of Electrical Power}

Reliability of electric power consists of:

a. assuring a source of power and

b. assuring continued distribution of power to where it is used.

Considerable experience exists in assuring the supply of electrical power for critical functions in hospitals, communication facilities, computer facilities and the like. However, elevator evacuation is a unique 
application, and the approach to assure reliability of electric power must be appropriate to the application. While it is beyond the scope of this paper to determine what components are needed to assure reliable power for elevator evacuation, the following discussion should be helpful for those making such determinations.

Some components that can be used to ensure reliability of power are fire protected distribution, redundant feeds, power from multiple substations outside the building, and emergency generator sets. Because elevator evacuation can tolerate short duration power loss, uninterruptable power supplies are not necessary. Any consideration of reliability of electric power should consider potential causes of power failure and the consequences of that failure.

Concern about interruption of power supplied by the local utility is not as important for elevator evacuation as it is for many other applications. Applications such as hospitals and many communication facilities operate most or all of the time, and they need highly reliable power for all the time that they operate. Emergency evacuation by elevators is different in that this mode of elevator operation is only needed during a building fire. At most, the EEES would be expected to operate during a fire situation for a few hours over the life of the building ${ }^{4}$. The probability of simultaneously having a fire and having the utility company power interrupted is relatively small, provided that the fire and power failure do not have the same cause (for example an earthquake). However, the probability of having a power distribution failure during a fire is relatively high. This is because fire frequently damages electrical distribution within buildings.

The location of electrical components has an impact on reliability of electrical power as is illustrated by the following discussion of feeders in hoistways and emergency generator sets. Electrical feeders located inside a hoistway are protected by the fire endurance of the hoistway. Further, loss of these feeders due to fire exposure in the hoistway has no impact on evacuation, because fire in the hoistway would have already rendered the EEES useless. Thus, feeders inside the hoistway do not need any special fire protection. If an emergency generator set is at a location remote from the elevator mechanical room, the power feeders from the generator will need fire protection. However, if the generator set is inside the mechanical room, the power feeders will not need any special fire protection for the same reason as the feeders inside a hoistway.

The level of reliability needed and the appropriate components needed to achieve that reliability depend on the particular evacuation system and on the total level of fire protection in the building. Some buildings may only need fire protection for the power distribution system, and other buildings may need emergency generator sets.

\subsection{Earthquake}

The probability of a fire starting during an earthquake or in the time of emergency following an earthquake may be little different than at other times. Earthquakes often damage utilities including water distribution systems, and earthquakes often place a high demand on the fire departments for rescue and medical aid. It is not surprising that the fires that do start during these times often become large and result in considerable property damage.

${ }^{4}$ An EEES may also operate during fire drills and testing. 


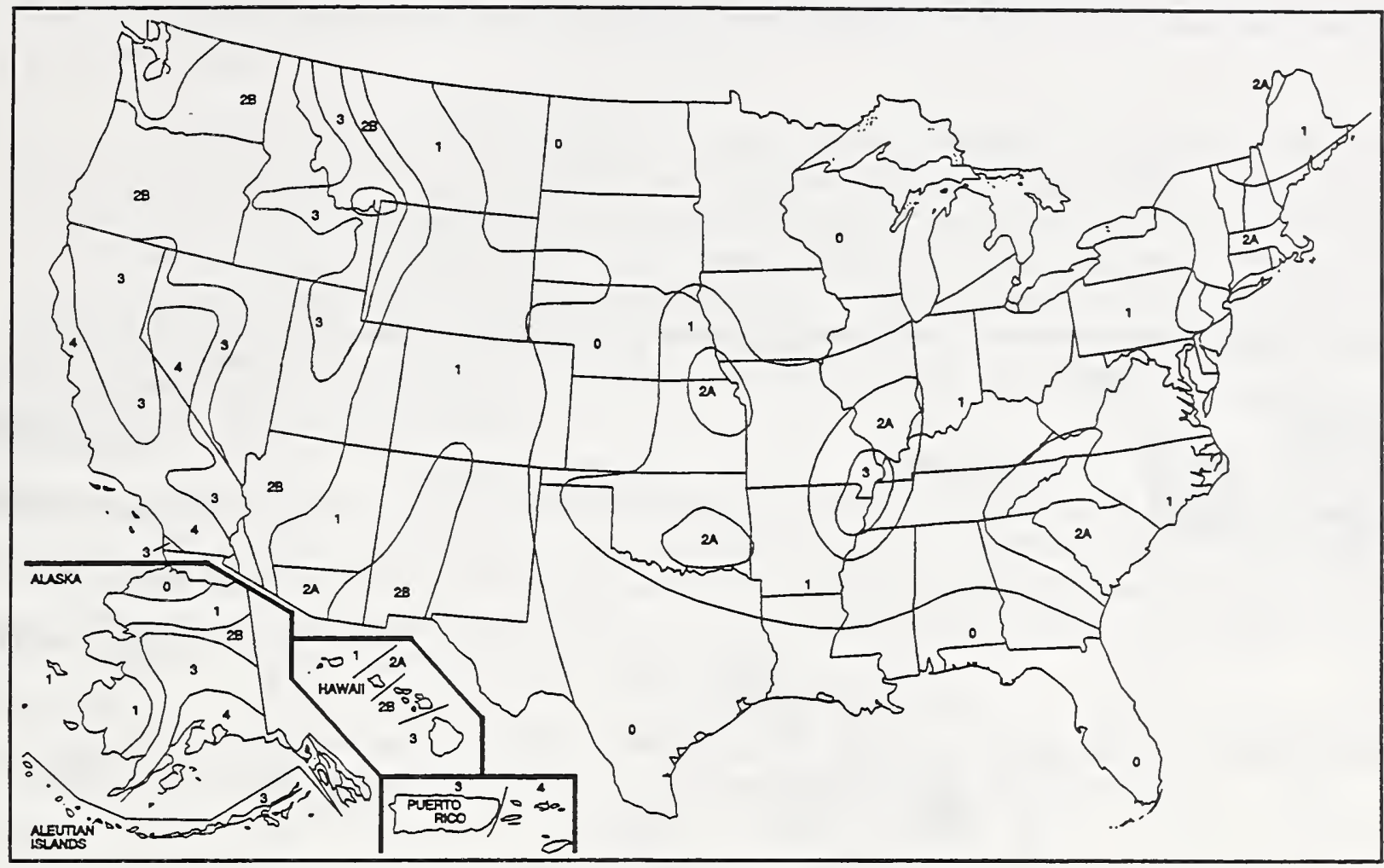

Figure 12. Seismic zone map of the United States (UBC 1993)

For the convenience of the readers, a brief description of the current approach to seismic protection is provided. However, this section is in no way intended to be a substitute for the codes, and designers should use applicable codes directly. Part XXIV of the ASME A17.1 Elevator Code (ASME 1993) addresses safety requirements for seismic zones 2 and greater. Seismic zones are defined by the model building codes (BOCA 1993; SBCCI 1988; UBC 1988 and 1993) based on professional judgement. There are some differences between these definitions. The Uniform Building Code (UBC) definition is shown in figure 12 to give the readers an idea of these zones. The UBC zones were selected because the FAA uses the UBC for earthquake design.

In zone 2, strengthening of rails and other structural elements is required. In seismic zones 3 or greater, a major concern is a collision between the elevator car and the counterweight ${ }^{5}$ that has been dislodged from its rails. The rails and other structural elements are strengthened to withstand a horizontal acceleration of $1 / 2 g$ or greater ${ }^{6}$. Additionally, if a seismic switch senses such an acceleration, elevators are put into the emergency mode described below. For moving cars, the emergency mode consists of an emergency stop, followed by motion away from the counterweight at low speed to the nearest available floor, open doors and shut down. Cars not moving, when an earthquake is sensed, remain inactive.

${ }^{5} \mathrm{~A}$ counterweight is a mass that is moved up and down in the opposite direction from the elevator car to conserve energy.

${ }^{6} g$ is the acceleration of gravity, which is about $9.8 \mathrm{~m} / \mathrm{s}^{2}\left(32 \mathrm{ft} / \mathrm{s}^{2}\right)$. 


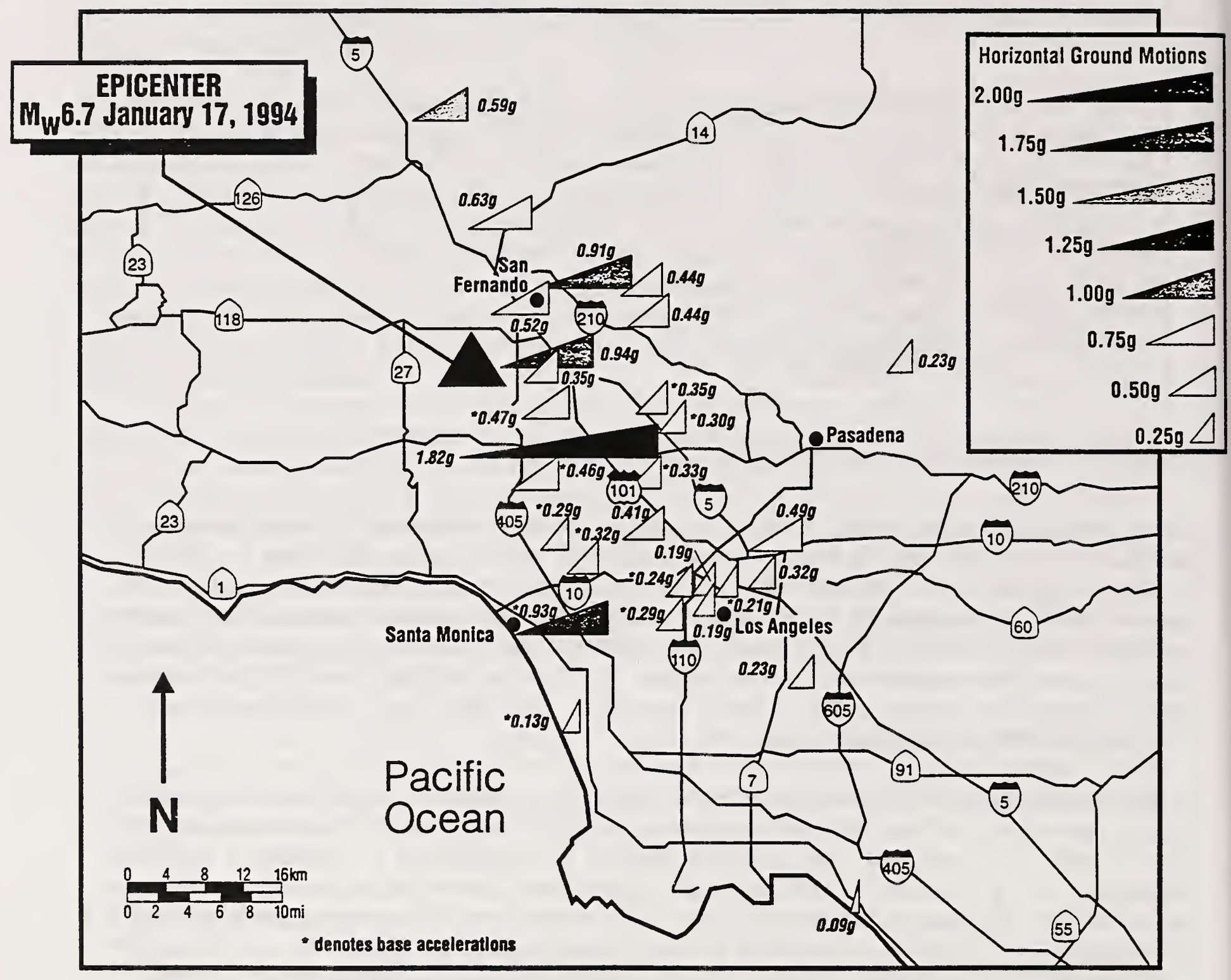

Figure 13. Peak horizontal accelerations at ground level during the Northridge earthquake (EQE 1994) 
Further, this emergency mode is also activated if a displacement switch indicates that the counterweight has been derailed.

As an example of the accelerations that can occur during earthquakes, figure 13 shows maximum horizontal accelerations at ground during the Northridge earthquake (EQE 1994). There were many locations during this earthquake that had accelerations at ground level lower than $1 / 2 g$. The acceleration that activates a seismic switch is that at the seismic switch not that at ground. Typically, flexible structures (for example steel structures) will encounter lower accelerations than those at ground. A seismic switch in a flexible structure would be expected to encounter lower accelerations than those at ground. Thus during an earthquake, there are many locations where accelerations are less than $1 / 2 g$, and the elevators will continue to operate.

The approach described above requires that elevators be able to operate under accelerations up to $1 / 2 g$ and takes the elevators out of service in an orderly manner when higher accelerations are detected. While it is theoretically possible to develop elevators that could operate through much higher accelerations, development of such elevators would be a large effort, and there is no assurance that such elevators would be affordable. Further research is needed in this area.

The earthquake requirements of ASME A17.1 only apply to new buildings. It is recommended that this approach to seismic protection be used for EEESs in seismic zones 3 and greater.

\section{Availability}

When an elevator in an EEES is out of service for scheduled or unscheduled maintenance, it cannot be used for evacuation. If there are many elevators in a building, the number of elevators used for evacuation can be selected to allow for a percentage that may be out of service.

In buildings with only one elevator, the above redundancy approach to assuring availability is not possible. Two other approaches to maximize availability are off hours maintenance and short turn around repairs. Scheduled maintenance can be done during off hours when the building is shut down or in a low state of activity. Maintenance contracts can put a premium on fast repair for unscheduled maintenance. When an elevator is out of service, a sign should clearly indicate this so that valuable evacuation time is not wasted waiting for an elevator that can not come.

\section{Elevator control}

Readers are familiar with automatic elevator controls that are common in passenger elevators in most of the world. There are two other modes of operation: elevator recall and firefighters operation. Upon alarm of a smoke detector in an elevator lobby, the elevator goes into a recall mode in which the car is moved to the exit landing and removed from service. In the event of a fire on the exit floor, the elevator goes to an alternate floor and is taken out of service. ASME A17.1 refers to this recall as Phase I. The landing to which the car is moved is the exit floor or an alternate floor if smoke was detected on the exit floor. After recall, firefighters can operate the elevator, and such operation is under the control of the firefighter inside the elevator. ASME A17.1 calls firefighters operation Phase II. 
Some approaches that might be used to control elevators during an elevator emergency evacuation are:

1. normal use (with less sensitive detectors),

2. Phase II, and

3. other mode of elevator operation.

In an EEES, the elevator (including the elevator lobbies, hoistway and machine room) is protected from the fire effects as discussed above. Thus the elevator is operating in an environment without fire. There is no physical reason why an elevator so protected cannot continue to operate normally provided that the smoke detector in the elevator lobby does not go into alarm. As stated earlier, an alarm from this smoke detector will result in Phase I elevator recall. Typical smoke detectors are very sensitive, and they can be put into alarm by a quantity of smoke so small that a person might not notice. Such small amounts of smoke may enter the lobby when lobby doors are opened for evacuation. Such low levels of smoke are not a tenability concern. To avoid unwanted elevator recall, the smoke detectors in the elevator lobbies that initiate Phase I operation can be replaced with less sensitive detectors such as heat detectors.

Using normal operation during evacuation is not appropriate for evacuation of large numbers of people, where a full elevator car might stop at every floor on its way to the exit floor. However, normal mode would be appropriate for evacuation of small numbers of people, such as a few persons with disabilities in an office building or the small number of workers in an ATCT. The computer program for elevator evacuation (ELVAC) by Klote, Alvord, Levin, and Groner (1992) can be used to estimate time for elevator evacuation.

The fire service, using Phase II operation, could also use elevators for evacuation of small numbers of people. Further, it is possible that building personnel could operate the elevators under Phase II for evacuation before the fire service arrives. Use of Phase II by non-fire service people would require that the elevator operators be trained and that the general approach not adversely affect fire service operations. Phase II service must only be provided by people who are aware of the location and extent of the fire and of its potential for endangering people using elevators.

For completeness, approach 3, is listed above. A mode of elevator operation could be developed specifically for emergency evacuation. Features that could be considered for this fire evacuation mode might include the ability to prioritize evacuation and the ability to cancel calls from a floor with untenable conditions in the elevator lobby. Such capabilities may be needed for evacuation of large numbers of people. However, these capabilities are not consistent with the elevator system under discussion in this paper. For a system used by a relatively few people, the time saved by prioritizing operations would not be significant. Further, the EEES of this paper protects against untenable conditions in the elevator lobbies. In the event of a failure of this protection, the elevator is recalled and the system is taken out of service. Thus this other mode of elevator operation is not appropriate for the EEESs of this paper. 


\section{Part II Application of Elevator Evacuation to ATCTs}

\section{Human considerations}

Designing and building elevators that can be safely used during a fire emergency is only half the job. The building occupants must be willing to use the EEES and be able to use it. As part of this project, visits were made to the 13 ATCTs listed in table 2. During these visits, interviews were conducted with air traffic controllers and facilities personnel that use the ATCT. This section is an overview of what was known about this topic before the visits and what was learned from the visits. For more detailed information about human considerations of EEESs at ATCTs readers are referred to Levin and Groner (1994). For information about human considerations of general evacuation using elevators, readers are referred to Groner and Levin (1992). Levin and Groner (1992) provide related information about human considerations of areas of refuge for persons with mobility limitations.

Table 2.

FAA air traffic control towers visited

\begin{tabular}{||ll||}
\hline Location & Design \\
\hline Scottsdale, SDL & Leo Daly Low \\
Andrews AFB, ADW & Pei \\
Washington/Dulles, IAD & non-standard \\
Detroit/Metro-Wayne, DTW & Leo Daly Major \\
Baltimore/Wash, BWI & non-standard \\
Metro Oakland, OAK & non-standard \\
Bates Field (Mobile), MOB & Lart \\
Sarasota/Bradennton, SRQ & Mock \\
Ontario Int'l, ONT & Golman Rolf \\
Van Nuys, VNY & Type O \\
Philadelphia, PHL & Welton Becket \\
Atlantic City, ACY & Golman Rolf \\
Tetersboro, TEB & AVCO \\
\hline
\end{tabular}

The interviews consisted of informal discussions that lasted about 15 minutes. Considering the twenty year campaign to teach people not to use elevators during fires, it was expected that occupants would have a strong preference for using stairs during fires. It was not surprising that nearly all those interviewed expressed a strong preference for using stairs as the first choice escape route. There were considerable differences among the interviewees on how willingly they would use elevators if there was smoke in the stairs. A few would use it without hesitation, and a few indicated they would try other alternatives (wait for helicopters, escape to catwalk, or use ladders). The majority indicated that they would use elevators if it were necessary with little delay but with considerable concern. 
At some ATCTs there were complaints about elevator service. It is well known in the elevator industry that buildings with only one elevator have more complaints about out-of-service elevators than buildings with multiple elevators. When there is only one elevator, occupants have to walk when elevators are not operating. In addition to complaints about out-of-service elevators, there were complaints about rough rides, and at one ATCT a cable for the counterweight had broken. While none of these occurrences were life threatening, the occupants at these towers were emphatic in expressing reluctance about elevators for fire evacuation. At ATCTs with few complaints about elevator service, occupants were more willing to accept the idea of EEES. Good maintenance of the elevator will encourage people to trust the EEES.

Communications is important to inform people waiting for elevators of the status of elevator evacuation and to inform people outside the building about the status of those waiting. The communication devices can be intercoms or telephones, but they must be capable of two way conversation. One device is needed in each elevator lobby, and another is needed at a location accessible to the emergency personnel.

In order to develop confidence in EEESs, education is needed to describe the safety features. Such education should also address general aspects of fire evacuation. This education can be by a combination of formal training classes, viewing videos, performing fire drills, reading an emergency plan and group discussions. Levin and Groner (1994) provide more information about such education.

\section{Criteria}

There are many approaches that can be taken to elevator evacuation, and some criteria are needed to evaluate modifications to ATCT and to develop EEES at new ATCTs. For the discussions of this paper, all of the following items are needed for EEES:

a. The elevator evacuation system is separate from any other means of egress.

b. The doors between the elevator lobby and the rest of the building automatically close in the event of a building fire.

c. The hoistway, elevator machine room and elevator lobby are protected by 1 hour fire barriers for hoistways three floors or less in height and by 2 hour fire barriers for all other elevators.

d. The hoistway, elevator machine room and elevator lobby are protected from smoke with a pressurization system or with a naturally ventilated smokeproof enclosures.

e. The hoistway and the machine room are protected from water by one of the following:

1. A combination of sealed elevator lobby doors, sloped floors, floor drains and sealing the hoistway walls.

2. Water resistive elevator components developed and approved for this application including the combination of building components (sealed elevator lobby doors, sloped floors, floor drains and sealing the hoistway walls) for which the water resistant components were developed. 
3. The elevators mounted on the building exterior that normally operate in the elements plus gasketing or seals on the elevator lobby doors.

4. The hoistway separated from the building by an exterior elevator lobby at each floor (see figure $11 \mathrm{a}$ or $11 \mathrm{~b})$.

f. The machine room is cooled by air conditioning equipment dedicated to this application. This air conditioning equipment is protected by fire barriers as described in item $\mathrm{c}$ and with electrical power as described in item $\mathrm{g}$.

g. Reliability of electrical power for the emergency elevator evacuation system is assured by a standby generator that is protected by fire barriers as described in item c. All power distribution to the elevator system is redundant and protected by fire barriers as described in item c.

h. The mode of elevator control shall be approved for the number of people intended to use the elevator during an emergency evacuation.

i. The elevator capacity is sufficient for emergency elevator evacuation.

j. In seismic zones 3 or greater, elevator equipment shall meet the seismic requirements of ASME A17.1.

Information has been provided about the topics above except for item i. The elevator capacity needs to be sufficient so that all the people who are intended to use the system can be evacuated safely. The following example is based on sizing the elevator car so that elevator evacuation can be conducted in a small number of trips.

Currently, ATCTs are restricted to people without mobility limitations. Accordingly, this discussion does not include people in wheelchairs but it could be adapted to include wheelchairs ${ }^{7}$. Strakosch (1983) indicates that a person standing needs about $0.28 \mathrm{~m}^{2}\left(3 \mathrm{ft}^{2}\right)$ to feel comfortable, and a person can be crowded into about $0.19 \mathrm{~m}^{2}\left(2 \mathrm{ft}^{2}\right)$. For this discussion, the space occupied by a person on an elevator during evacuation is selected arbitrarily at $0.2 \mathrm{~m}^{2}\left(2.2 \mathrm{ft}^{2}\right)$. For this example, the ATCT normally has about 14 people and has 28 at shift change. If it is desired to be able to move these people in four trips, the elevator must be able to hold 7 people at a time. The elevator car needs to have an area of about $7 \times 0.2=1.4 \mathrm{~m}^{2}\left(15 \mathrm{ft}^{2}\right)$.

\section{Retrofit ATCTs}

This section shows that adaptation of existing ATCTs for EEES is not feasible. The ATCTs are listed in table 3, and figures 14 to 73 are elevations and floor plans of nine standard design ATCTs and three non-standard ATCTs. Most control towers have elevators, but table 3 shows that the Mock and Hunt

${ }^{7}$ The Department of Justice (1991) indicates that a person in a wheelchair needs a floor space of $0.76 \mathrm{~m}$ $(2.5 \mathrm{ft})$ by $1.22 \mathrm{~m}(4 \mathrm{ft})$, which is an area of $0.93 \mathrm{~m}^{2}\left(10 \mathrm{ft}^{2}\right)$. 


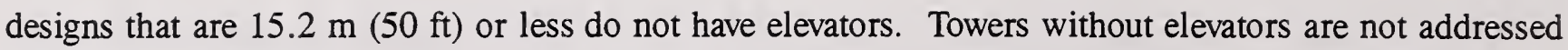
further in this report.

Table 3. Standard and non-standard design FAA air traffic control towers

\begin{tabular}{|lccc||}
\hline ATCT & Design $^{1}$ & Activity & Elevator \\
\hline \hline Leo Daly Major & S & MAL & Yes \\
Welton Becket & $\mathrm{S}$ & MAL & Yes \\
Pei & $\mathrm{S}$ & MAL & Yes \\
LART & $\mathrm{S}$ & IAL & Yes \\
Mock & $\mathrm{S}$ & IAL & Some \\
Golman Rolf & $\mathrm{S}$ & IAL & Yes \\
AVCO & $\mathrm{S}$ & LAL & Yes \\
Hunt & $\mathrm{S}$ & LAL & Some \\
Leo Daly Low & $\mathrm{S}$ & LAL & Yes \\
Type O & $\mathrm{S}$ & LAL & Yes \\
Oakland & NS & MAL & Yes \\
Washington Dulles & NS & MAL & Yes \\
Baltimore Washington & NS & MAL & Yes \\
\hline \hline
\end{tabular}

${ }^{1} \mathrm{~S}$ for standard design and NS for non-standard design.

${ }^{2}$ LAL for low activity level, IAL for intermediate activity level and MAL for major activity level. ${ }^{3}$ These ATCTs have elevators if the height from ground level to the cab is greater than $15.2 \mathrm{~m}$ (50 $\mathrm{ft})$.

\subsection{Standard and Non-Standard Designs}

The FAA classifies ATCTs as standard and non-standard. Standard ATCTs are designed by architectural firms under contract to FAA Washington Headquarters and are owned by FAA. Standard designs are adapted to the specific airport, which usually includes selection of the tower height based on the requirements of the specific airport (see elevations of standard ATCTs in figures 14, 20, 26, 35, 40, 45, 50 and 55). The majority of non-standard ATCTs are operated by FAA but are designed and owned by the sponsor (such as local governments and the military).

Non-standard designs are developed when local authorities desire the ATCT to be in architectural harmony with its surroundings. The non-standard designs discussed in this report are Oakland Metro, 
Washington Dulles and Baltimore Washington, and for elevations of these towers see figures 60, 64 and 70). These towers were selected to provide a general idea of the variations that are possible in nonstandard designs.

The arrangements shown for the standard ATCTs are general, and actual towers built to these designs have differences due to plan changes made during construction and post-construction modifications. However, consideration of the many possible deviations from the general arrangements is beyond the scope of this paper. The Hunt ATCT is listed in table 3, but drawings of it are not provided because its floor plan is the same as that of the AVCO. Because all of the comments that apply to the AVCO also apply to the Hunt, the Hunt design is not discussed further.

The top floor, referred to as the cab, of an ATCT is where controllers observe aircraft both in the air and on the ground. With the exception of window mullions, controllers have 360 degrees of view from the cab (figures 19, 25, 29, 34, 39, 44, 49, 54, 59, 63, 69 and 73).

\subsection{Location of Top Elevator Landing}

Generally, elevators extend from the ground floor to the subjunction floor, which is located two floors below the cab. Controllers walk up to the junction floor and then to the cab. Frequently the junction floor has a break room where controllers can relax when they are not controlling traffic, attending instruction or participating in other official duties. In the Leo Daly Major design (figures 13-19), the elevator stops three floors below the cab. In the LART (figures 30-34), the Leo Daly Low Activity (figures 50-54), the Oakland Metro (figures 60-63) and the Baltimore Washington International (BWI) (figures 70-73) the top elevator landing is one floor below the cab.

\subsection{Separate Means of Egress}

In order for an EEES to be a separate means of egress, a person must be able to travel to the EEES and through it to the outside without going through any other means of egress. Some elevators open into stairs which makes it impossible for the stairs and the EEES to be separate means of egress. These towers are the Pei (figures 26-29), the AVCO (figures 45-49) and the Type O (figures 55-59).

In most of the ATCTs, a person on the cab level must travel through the exit stairs to get to the elevator. For these ATCTs, the elevator is not adaptable as a second means of egress, unless extensive modifications were made to the building. The Golman Rolf is an example, a person on the cab (figure 44) goes down the stairs to the junction floor (figures 43), and then enters to exit stairs to go to the subjunction floor (figure 42) where he or she can leave the exit stairs to take the elevator. If these exit stairs are blocked by smoke, the person cannot get to the elevator.

The LART and the Leo Daly Major are the only towers where a person does not need to travel from the $\mathrm{cab}$ through the exit stairs to get to the elevator. Both of these standard designs, a person in the stairs can travel directly to the outside, and a person in the elevator can travel directly to the outside. Thus it would be possible to adapt the elevators at the LART and the Leo Daly Major to be separate means of egress, but difficulties with water protection discussed below prevent the elevators at these towers from being adaptable to EEESs. There may be variations of some other standard designs where the elevator could be a separate means of egress. 


\subsection{Enclosed Lobby}

An EEES must have an enclosed elevator lobby, and the Leo Daly Major (figures 15 and 16), LART (figures 31, 32 and 33), Mock (figures 36 and 37), Golman Rolf (figures 41 and 42), Leo Daly Low Activity (figures 51, 52 and 53), Oakland Metro (figures 61 and 62), Dulles (figures 66 and 67) and BWI (figure 71) have a separate lobby or space that could be modified for such a lobby. The Welton Becket has an elevator lobby open to the outside at the typical floor. However, modification of the lobby to prevent water from reaching elevator equipment is not feasible for the reasons discussed below.

\subsection{Water Protection}

For water protection, the modifications required are a combination of elevator doors with seals, sloping doors and floor drains discussed above. The addition of automatic closing doors with seals is not complicated. However, sloping floors up to the elevator doors requires that the elevator doors be removed and reinstalled a short distance higher [possibly $50 \mathrm{~mm}(2 \mathrm{in})$ ]. This entails relocating all of the electronic and electrical connections and components that are part of the doors. Because the doors are raised the lintels above the doors must be removed and replaced with new ones. This may require structural analysis. Installation of a trench floor drain would weaken the floor, and a structural analysis would have to be made to determine if it is possible to strengthen the floor to allow the drain. In addition to the considerable expense of these modifications, they would require that the elevators be out of operation for an extended period during which the building occupants would have to walk up and down the stairs. This down time would be at least several weeks, and possibly even months. Considering the complexity of these modifications and elevator down time, it is concluded that modification of the lobby to prevent water from reaching elevator equipment is not feasible.

In the future water resistant elevator components could be developed which could be installed with less extensive modifications. In this case it might be possible to modify the LART with an EEES.

\section{New ATCTS}

The criteria discussed above can be applied to new ATCTs, and the preceding discussions provide information about applying that criteria. As already noted, ATCTs are restricted to people without mobility limitations. This restriction is under reevaluation by FAA and the Department of Justice. This evaluation includes issues of mobility requirements of air traffic controllers on the cab level that are beyond the scope of this paper. It is possible that at some time, the FAA may desire vertical transportation to the cab for people in wheelchairs. The following sections discuss some possibilities.

\subsection{Chairlifts}

Chairlifts can be used to move people from the top elevator floor to the cab level. In this approach, the stairs going down from the cab would need to be separate from both the exit stairs and the EEES. This approach allows adaptation of standard designs for new ATCTs. 


\subsection{Interior Elevators}

One challenge with using an interior elevator is to prevent the elevator from blocking the field of vision on the cab level. As already stated, controllers have 360 degrees of view from the cab, with the exception of window mullions. The shaft walls, elevator car and doors could be constructed of glass. However, there would still be some opaque components at corners and in doors. It is expected that the obstruction due to these components would be worse than that of window mullions. If this approach were considered, a study of the resulting field of vision and the impact on air traffic control might be needed.

\subsection{Modified Sidewalk Type Elevator}

An adaptation of sidewalk elevators could be made to eliminate the glass shaft walls. Sidewalk elevators are used in street front stores for moving freight from the street to the basement. These elevators have a vertical opening in the sidewalk with hinged doors that open automatically when the elevator ascends and descends. This elevator concept has already been adapted as the rooftop elevator that makes routine helicopter rooftop landing possible for buildings with limited roof space. While this approach would eliminate shaft walls in the cab, it would probably requite a glass elevator car. Further, sidewalk (and rooftop) elevators only serve two floors. If modified sidewalk type elevators were used at ATCTs, they would have to be in addition to the other elevators that serve the lower floors.

\subsection{Exterior Elevators}

Exterior elevators with glass cars and glass doors are available. As previously discussed, exterior elevators have considerable advantages concerning water protection. As with the interior elevators, this approach might need a study concerning the resulting field of vision. Considering the advantages of currently being on the market and of water protection, exterior elevators are the most practical approach to providing elevator service to the cab.

\section{Conclusions}

1. Elevator emergency evacuation is not feasible for existing ATCTs. This could change for some standard designs if water resistant elevator components are developed that make water protection of elevators feasible.

2. Elevator emergency evacuation is feasible for new ATCTs. However, development of elevator emergency evacuation for new ATCTs would require attention to detail concerning system protection, elevator control, occupant education and occupant communications. Elevator emergency evacuation is not yet accepted by codes (such as NFPA 101), and FAA may not want to build such systems until they are accepted. Further, it is possible that another approach to achieve life safety based on equivalency may have advantages over elevator emergency evacuation. (See the introduction of the main report about a separate effort at FAA that uses equivalency.) 


\section{Acknowledgments}

The authors wish to thank Robert Madison, FAA Project Manager for ATCT Life/Fire Safety Upgrade, for his considerable help during this project. Thanks are due to Edward A. Donoghue, Edward A. Donoghue Associates, Inc. and George Gibson, Gibson Consulting for their suggestions concerning elevator technology. 


\section{Nomenclature}

$a=$ thickness of gap in direction perpendicular to flow

$A=$ area

$A_{a}=$ free area around the elevator car

$A_{e}=$ effective area between the hoistway and the outside

$A_{i o}=$ leakage area between the building and the outside

$A_{r i}=$ leakage area between the lobby and the building

$A_{s}=$ cross-sectional area of the hoistway

$A_{s r}=$ leakage area between the hoistway and the lobby

$C=$ discharge coefficient, dimensionless

$C_{c}=$ flow coefficient for flow around car, dimensionless

$d=$ orifice diameter

$D=$ distance from floor to the top surface of the water

$D_{h}=$ hydraulic diameter of flow path; $D_{h}=2 a$

$g=$ acceleration of gravity

$H=$ height that water rises up the slope

$h_{1}=$ elevation at location 1

$h_{2}=$ elevation at location 2

$K_{c p}=$ coefficient from equation (1)

$K_{v}=$ coefficient from equation (7)

$K_{w}=$ coefficient from equation (4)

$L \quad=$ length of gap

$N P=$ dimensionless pressure difference

$N Q=$ nondimensional flow

$N Q=$ dimensionless flow rate

$p_{1}=$ pressure at location 1

$p_{2}=$ pressure at location 2

$Q=$ volumetric flow rate

$R_{e} \quad=$ Reynolds number, dimensionless

$V \quad=$ velocity of hose stream, in flow path or of elevator car

$V_{1}=$ velocity at location 1

$V_{2}=$ velocity at location 2

$x=$ depth of gap in flow direction

$\Delta p=$ pressure difference across flow paths (orifice, gap or door undercut)

$\Delta p_{\text {crit }}=$ critical pressure difference

$\nu=$ kinematic viscosity

$\rho \quad=$ density

$\rho_{1}=$ density at location 1

$\rho_{2}=$ density at location 2

$\rho_{s} \quad=$ air density in hoistway 


\section{References}

ASME 1993. Safety Code for Elevators and Escalators, A17.1, American Society of Mechanical Engineers, New York.

Barnett, C. 1992. Chapter 10 Analytical Tools to Evaluate Building Spacing, Compartment Sizing, and External Walls in Tall Buildings, Fire Safety in Tall Buildings, D. Sfintesco, Editor, McGraw, New York, NY.

Bazjanac, V. 1977. Simulation of Elevator Performance in High-Rise Buildings Under Conditions of Emergency, Human Response to Tall Buildings, Ed by D.J. Conway. Dowden, Hutchinson \& Ross, Stroudsburg, PA, pp 316-328.

Bazjanac, V. 1974. Another Way Out? Progressive Architecture, April, pp 88-89.

BOCA 1993. National Building Code, 12th ed, Building Officials \& Code Administrators International, Country Club Hills, IL.

Boring, D.F., Spence, J.C., Wells, W.G. 1981. Fire Protection Through Modern Building Codes, American Iron and Steel Inst., Washington, DC.

Bukowski, R.W., Peacock, R.D., Jones, W.W. and Forney, C.L. 1991. Technical Reference Guide for HAZARD I Fire Hazard Assessment Method, Version 1.1, NIST Handbook 146, Vol II, National Institute of Standards and Technology, Gaithersburg, MD.

Bushev, V.P. et al. 1978. Fire Resistance of Buildings, Second Edition, Translated from Russian, National Bureau of Standards, Gaithersburg, MD.

Campbell, J.A. 1991. Chapter 6-6 Confinement of Fire in Buildings, Fire Protection Handbook, National Fire Protection Association, Quincy, MA.

Degenkolb, J. 1991. Elevator Usage During a Building Fire, ASME Symposium on Fire and Elevators, Baltimore, MD, February 19-20, 1991, American Society of Mechanical Engineers, New York, NY, pp 76-79.

Department of Justice. 1991. Nondiscrimination on the Basis of Disability by Public Accommodations and in Commercial Facilities; Final Rule, Federal Register, Vol 56, No 144, Friday, July 26, 1991.

EQE 1994. The January 17, 1994 Northridge, California Earthquake, EQE International, San Francisco, CA.

FAA 1988. Airport Traffic Control Tower and Terminal Radar Approach Control Facility Design, FAA Order 6480.7B, Federal Aviation Administration, Washington DC.

Forney, G.P. 1989. Personal Communications at the Building and Fire Research Laboratory, National Institute of Standards and Technology, Gaithersburg, MD. 
Fox C.C. 1991. Handicapped Use of Elevators, ASME Symposium on Fire and Elevators, Baltimore, MD, February 19-20, 1991, American Society of Mechanical Engineers, New York, NY, pp 80-82.

Gatfield, A.J. 1991. Elevators and Fire: Designing for Safety, ASME Symposium on Fire and Elevators, Baltimore, MD, February 19-20, 1991, American Society of Mechanical Engineers, New York, NY, pp 95-107.

Groner, N.E. and Levin, B.M. 1992. Human Factors Considerations in the Potential for Using Elevators in Building Emergency Evacuation Plans, National Institute of Standards and Technology, NIST-GCR-92-615.

Gross, D. and Haberman, W.L. 1988. Analysis and Prediction of Air Leakage through Door Assemblies, Fire Safety Science, Proceedings of the 2nd International Symposium, Tokyo, Japan, pp 169178.

Klote, J.H. 1993. Design of Smoke Control Systems for Areas of Refuge, ASHRAE Transactions, American Society of Heating, Refrigerating and Air Conditioning Engineers, Atlanta, GA, Vol 99, Part 2, pp 793-807.

Klote, J.H. 1988. An Analysis of the Influence of Piston Effect on Elevator Smoke Control, Nat. Bur. Stand. (U.S.), NBSIR 88-3751.

Klote, J.H. 1984. Smoke Control for Elevators, ASHRAE Journal, VOL 26, No 4, pp 23-33.

Klote, J.H. and Tamura, G.T. 1991. Design of Elevator Smoke Control Systems for Fire Evacuation, ASHRAE Transactions, Vol 97, Part 2, pp 634-642.

Klote, J.H. and Tamura, G.T. 1986a. Elevator Piston Effect and the Smoke Problem, Fire Safety Journal, Vol 11, No 3, pp 227-233.

Klote, J.H. and Tamura, G.T. 1986b. Smoke Control and Fire Evacuation by Elevators, ASHRAE Transactions, Vol 92, Part 1A, pp 231-245.

Klote, J.H. and Tamura, G.T. 1987. Experiments of Piston Effect on Elevator Smoke Control, ASHRAE Transactions, Vol 93, Part 2A, pp 2217-2228.

Klote, J.H., Alvord, D.M., Levin, B.M., and Groner, N.E. 1992. Feasibility and Design Considerations of Emergency Evacuation by Elevators, National Institute of Standards and Technology, NISTIR 4870.

Klote, J.H., Deal, S.P., Levin, B.M., Groner, N.E., and Donoghue, E.A. 1992. Workshop on Elevator Use During Fires, National Institute of Standards and Technology, NISTIR 4993.

Klote, J.H. and Milke, J.A. 1992. Design of Smoke Management Systems, American Society of Heating, Refrigerating and Air-Conditioning Engineers, Atlanta, GA.

Klote, J.H., Nelson, H.E., Deal, S., Levin, B.M. 1992. Staging Areas for Persons with Mobility Limitations, National Institute of Standards and Technology, NISTIR 4770. 
Levin, B.M. and Groner, N.E. 1992. Human Behavior Aspects of Staging Areas for Fire Safety in GSA Buildings, National Institute of Standards and Technology, NIST-GCR-92-606.

Levin, B.M. and Groner, N.E. 1994. Human Factor Considerations in the Potential for Using Elevators for Fire Evacuation of FAA Control Towers, National Institute of Standards and Technology, NIST-GCR-94.

Madison, R.W. 1991. Elevator Operation in a High Temperature Environment, ASME Symposium on Fire and Elevators, Baltimore, MD, February 19-20, 1991, American Society of Mechanical Engineers, New York, NY, pp 80-82.

Marchitto, N. 1991. High Temperature Operation of Elevators, ASME Symposium on Fire and Elevators, Baltimore, MD, February 19-20, 1991, American Society of Mechanical Engineers, New York, NY, pp 25-31.

Miller, R.W. and Han, L.S. 1971. Pressure Losses for Laminar Flow in the Entrance Region of Ducts of Rectangular and Equilateral Triangular Cross Sections, Journal of Applied Mechanics, Vol. 38, pp 1083-1087.

Nelson, H.E. and MacLennan, H.A. 1988. Emergency Movement, SFPE Handbook of Fire Protection Engineering, Society of Fire Protection Engineers, Boston, MA.

NFPA 101, 1994. Code for Safety to Life from Fire in Buildings and Structures, National Fire Protection Association, Quincy, MA.

NFPA 101, 1976. Code for Safety to Life from Fire in Buildings and Structures, National Fire Protection Association, Quincy, MA.

NFPA 251, 1990. Standard Methods of Fire Tests of Building Construction and Materials, National Fire Protection Association, Quincy, MA.

Pauls, J. 1977. Management and Movement of Building Occupants in Emergencies, DBR Paper No. 788, National Research Council, Ottawa, Canada.

Pauls, J. 1988. People Movement, SFPE Handbook of Fire Protection Engineering, Society of Fire Protection Engineers, Boston, MA.

Pauls, J., Gatfield A.J., Juillet, E. 1991. Elevator Use for Egress: The Human-Factors Problems and Prospects, ASME Symposium on Fire and Elevators, Baltimore, MD, February 19-20, 1991, American Society of Mechanical Engineers, New York, NY, pp 63-75.

Robibero, V.P. 1991. High Temperature Operation of Elevators, ASME Symposium on Fire and Elevators, Baltimore, MD, February 19-20, 1991, American Society of Mechanical Engineers, New York, NY, pp 25-31.

SBCCI 1988. Standard Building Code, Southern Building Code Congress International, Birmingham, AL. 
Schmidt, W., and Klote, J.H. 1982. In Case of Fire--Use the Stairwells, Elevators aren't Safe, Specifying Engineer, Vol 47, No 5.

Strakosch, G.R. 1983. "Vertical Transportation: Elevators and Escalators", 2nd Edition, Wiley \& Sons, New York, NY.

Sumka, E.H. 1987. Presently, elevators are not safe in fire emergencies, ASHRAE Transactions, Vol. 93, Part 2, pp. 2229-2234.

Tamura, G.T. and Klote, J.H. 1987a. Experimental Fire Tower Studies on Elevator Pressurization Systems for Smoke Control, ASHRAE Transactions, Vol 93, Part 2, pp 2235-2257.

Tamura, G.T. and Klote, J.H. 1987b. Experimental Fire Tower Studies on Mechanical Pressurization to Control Smoke Movement Caused by Fire Pressures, Proceedings of the 2nd International Symposium on Fire Safety Science, Tokyo, Japan.

Tamura, G.T. and Klote, J.H. 1988. Experimental Fire Tower Studies on Adverse Pressures Caused by Stack and Wind Action: Studies on Smoke Movement and Control, ASTM International Symposium on Characterization and Toxicity of Smoke, December 5, 1988, Phoenix, AZ.

UBC 1988. Uniform Building Code, International Conference of Building Officials, Whittier, CA.

UBC 1993. Accumulative Supplement to the Uniform Building Code, International Conference of Building Officials, Whittier, CA. 


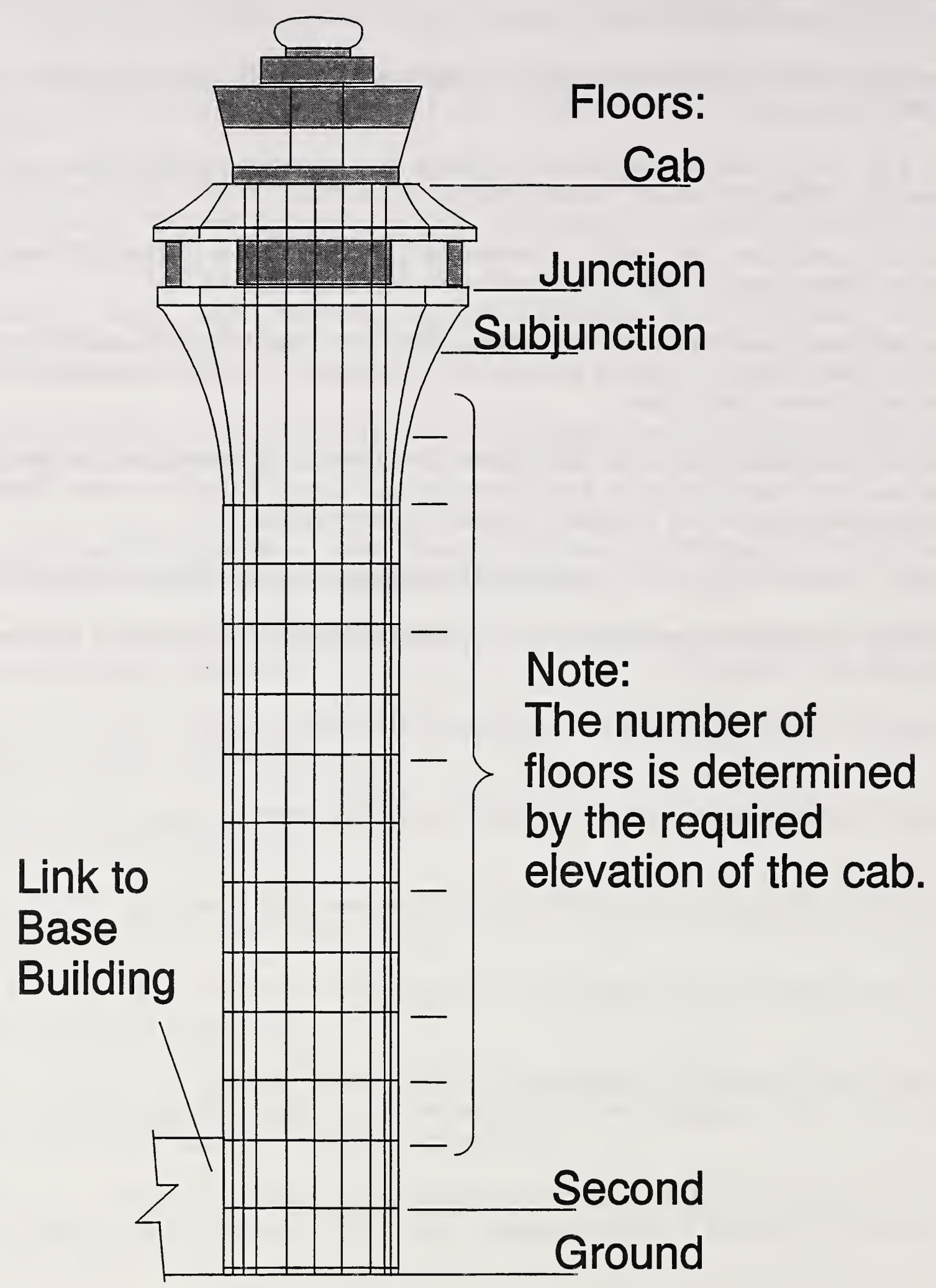

Figure 14. Elevation of the Leo Daly Major standard design ATCT 


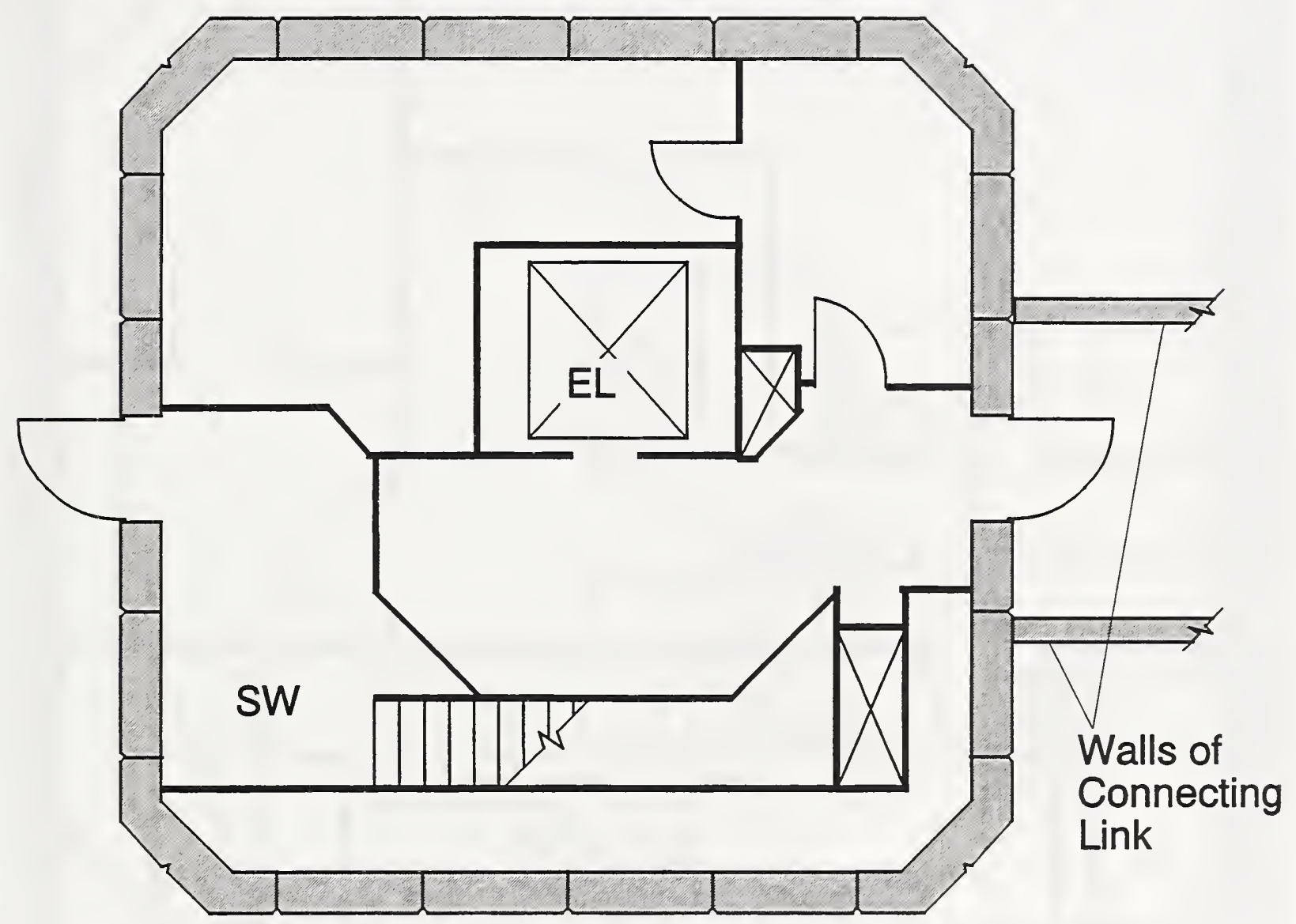

Figure 15. Ground floor of the Leo Daly Major standard design ATCT 


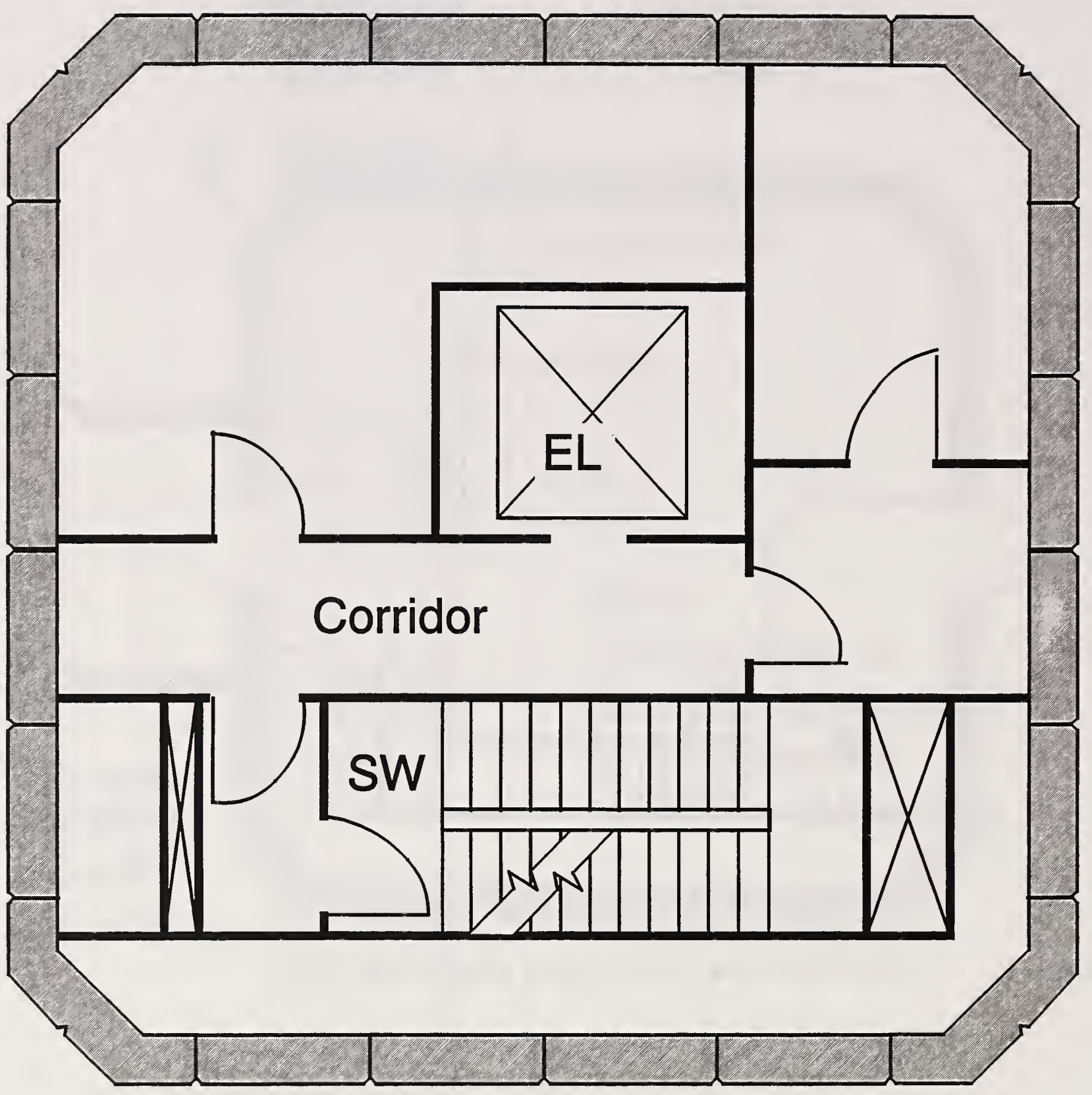

Figure 16. Typical floor of the Leo Daly Major standard design ATCT 


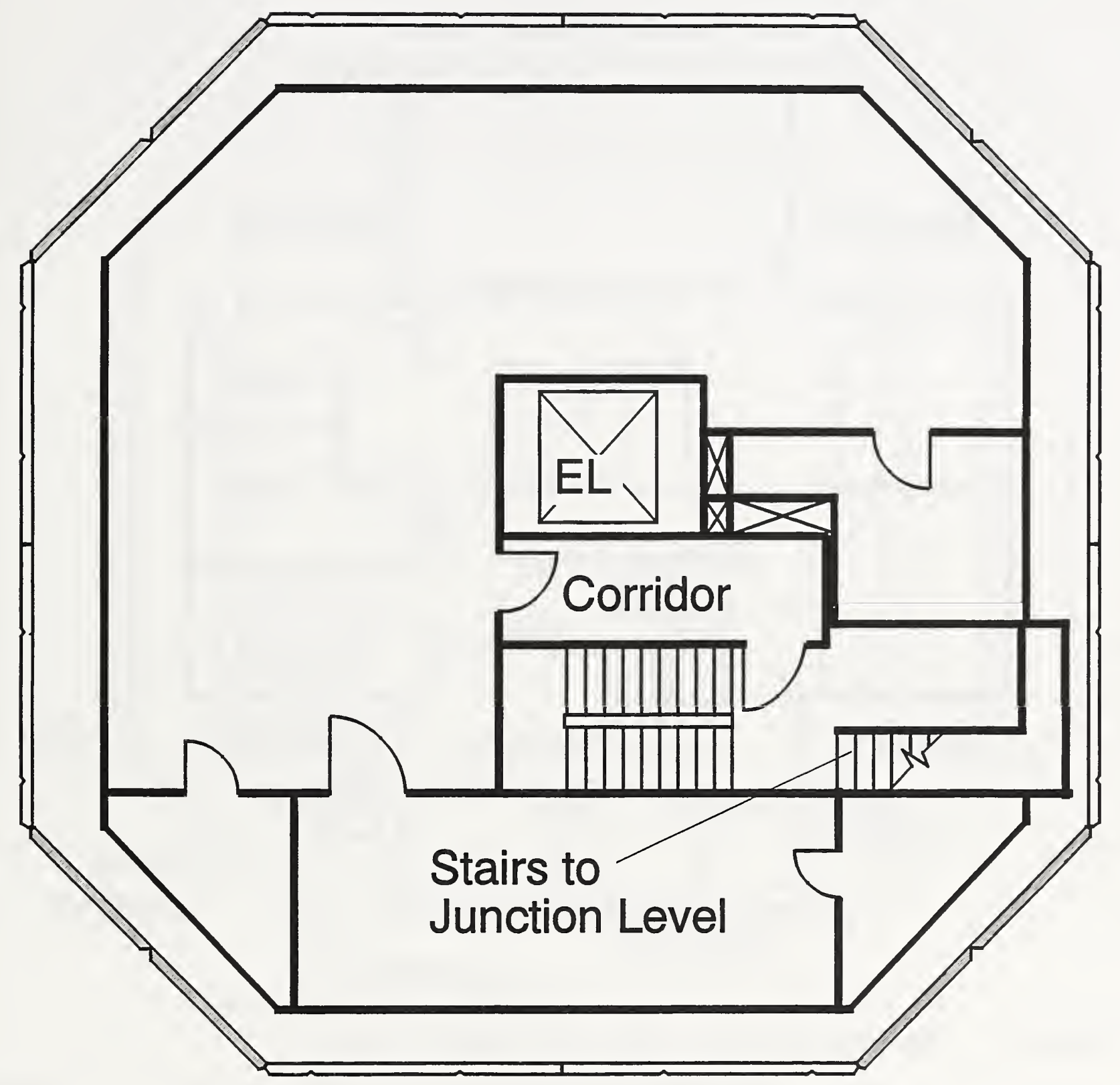

Figure 17. Subjunction floor of the Leo Daly Major standard design ATCT 


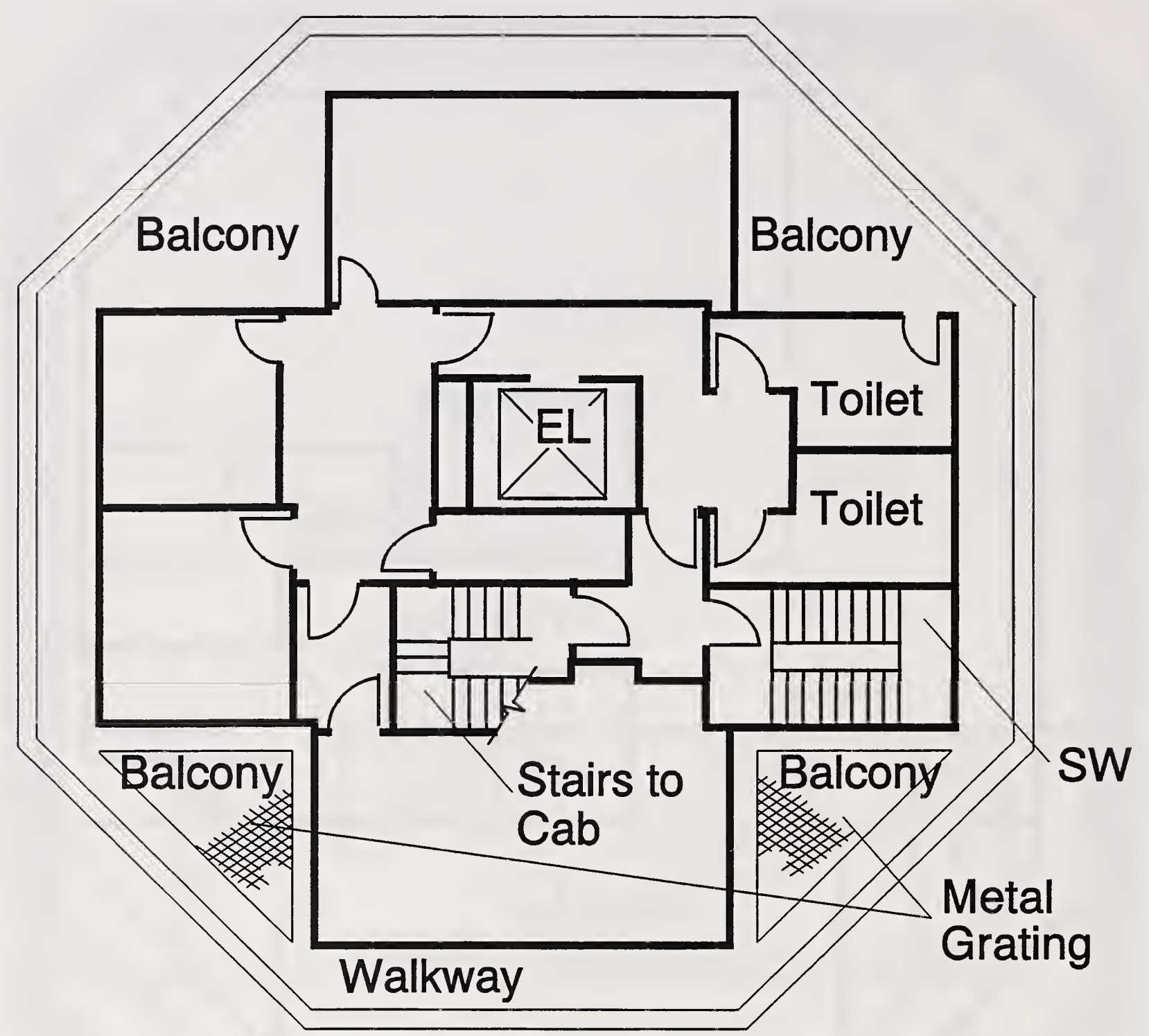

Figure 18. Junction floor of the Leo Daly Major standard design ATCT 


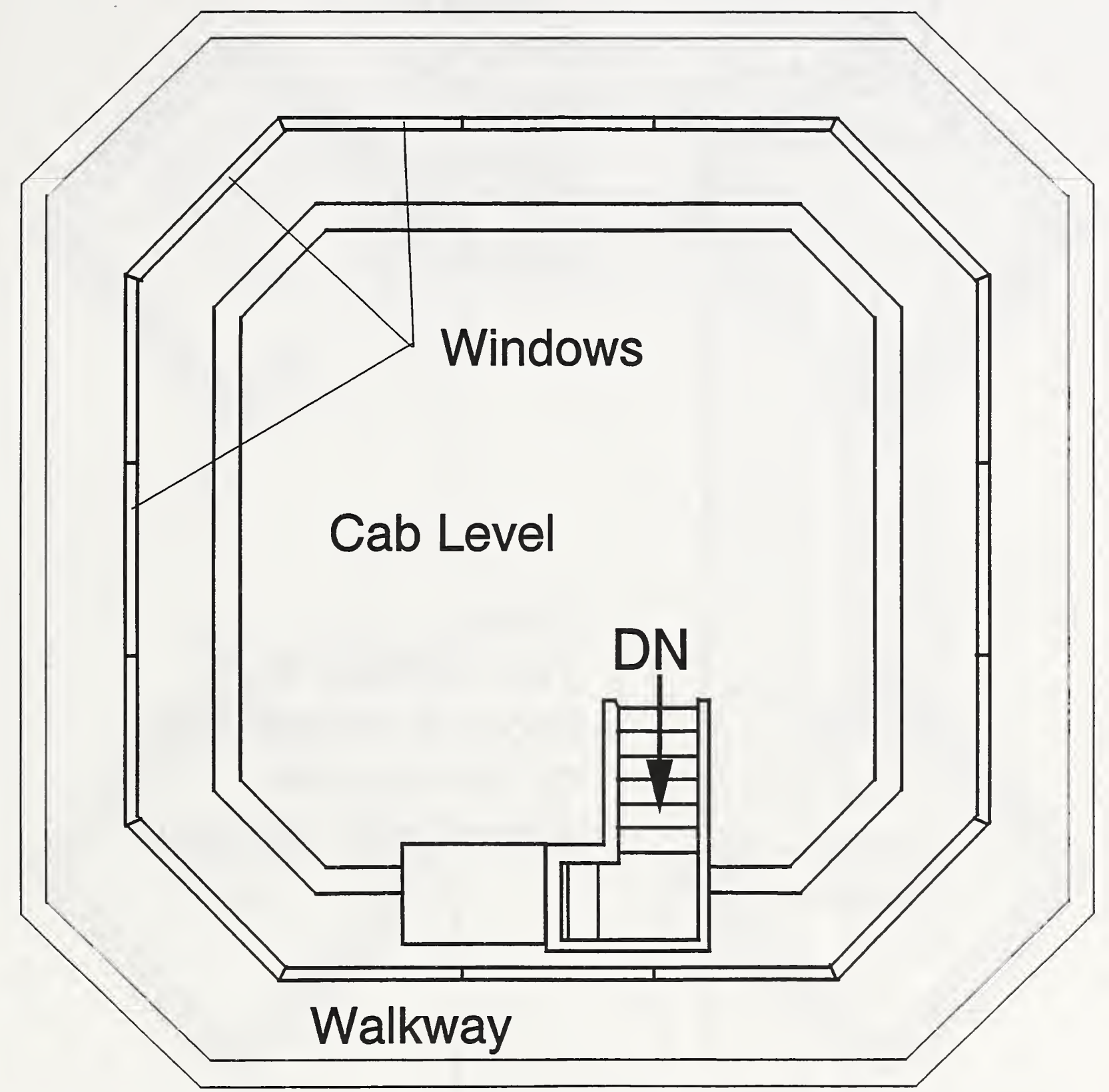

Figure 19. Cab floor of the Leo Daly Major standard design ATCT 


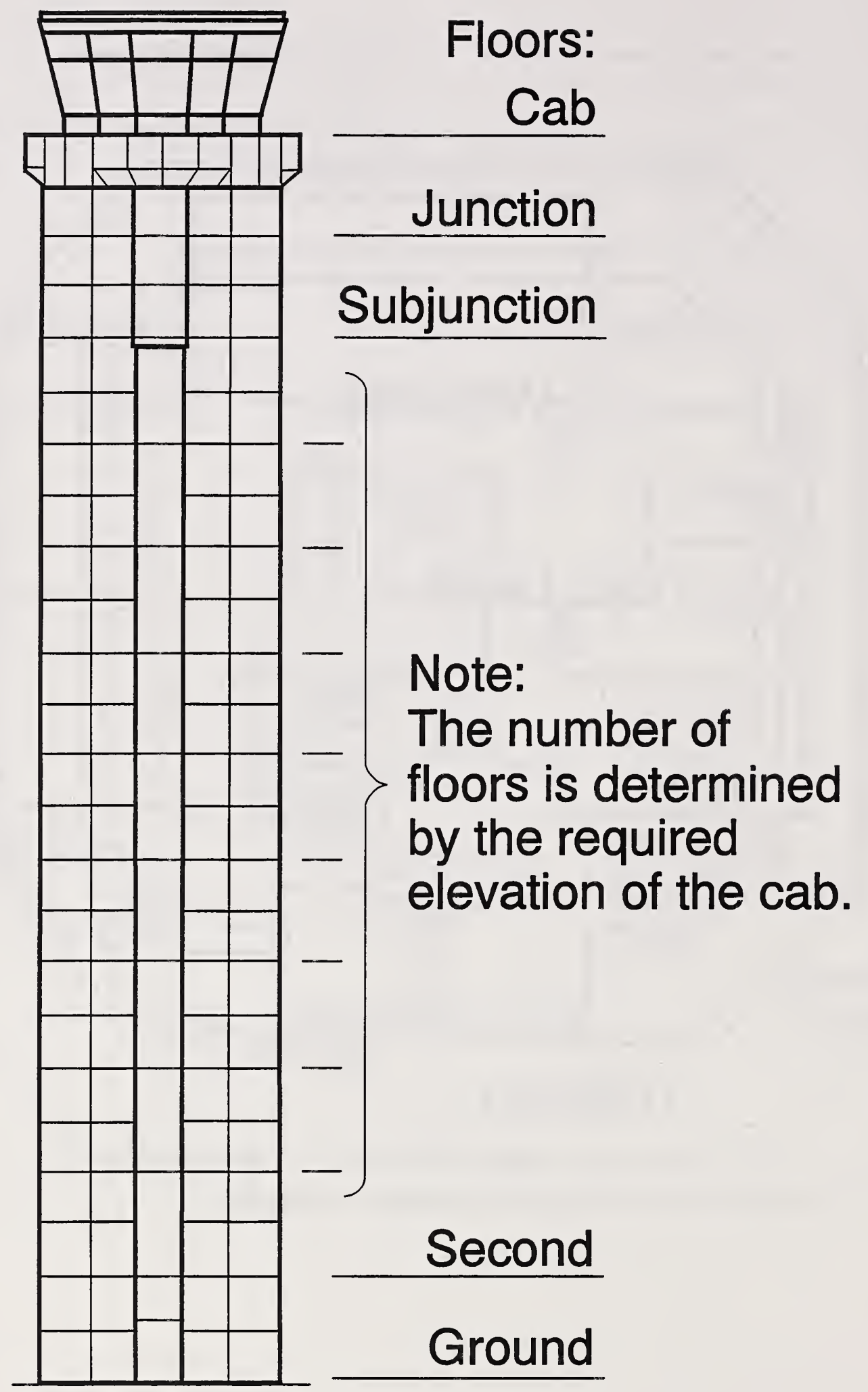

Figure 20. Elevation of the Welton Becket standard design ATCT 


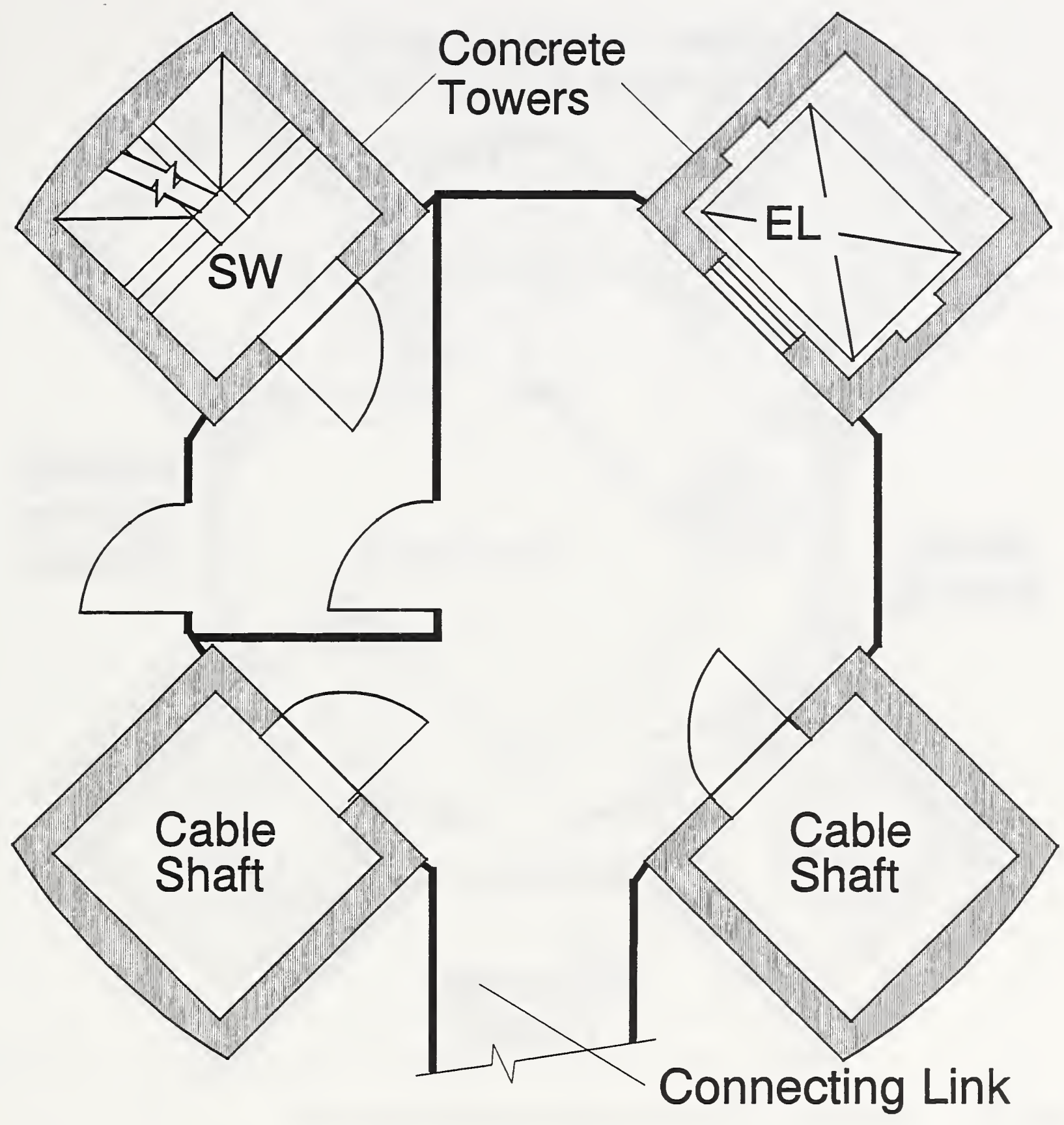

Figure 21. First floor of the Welton Becket standard design ATCT 


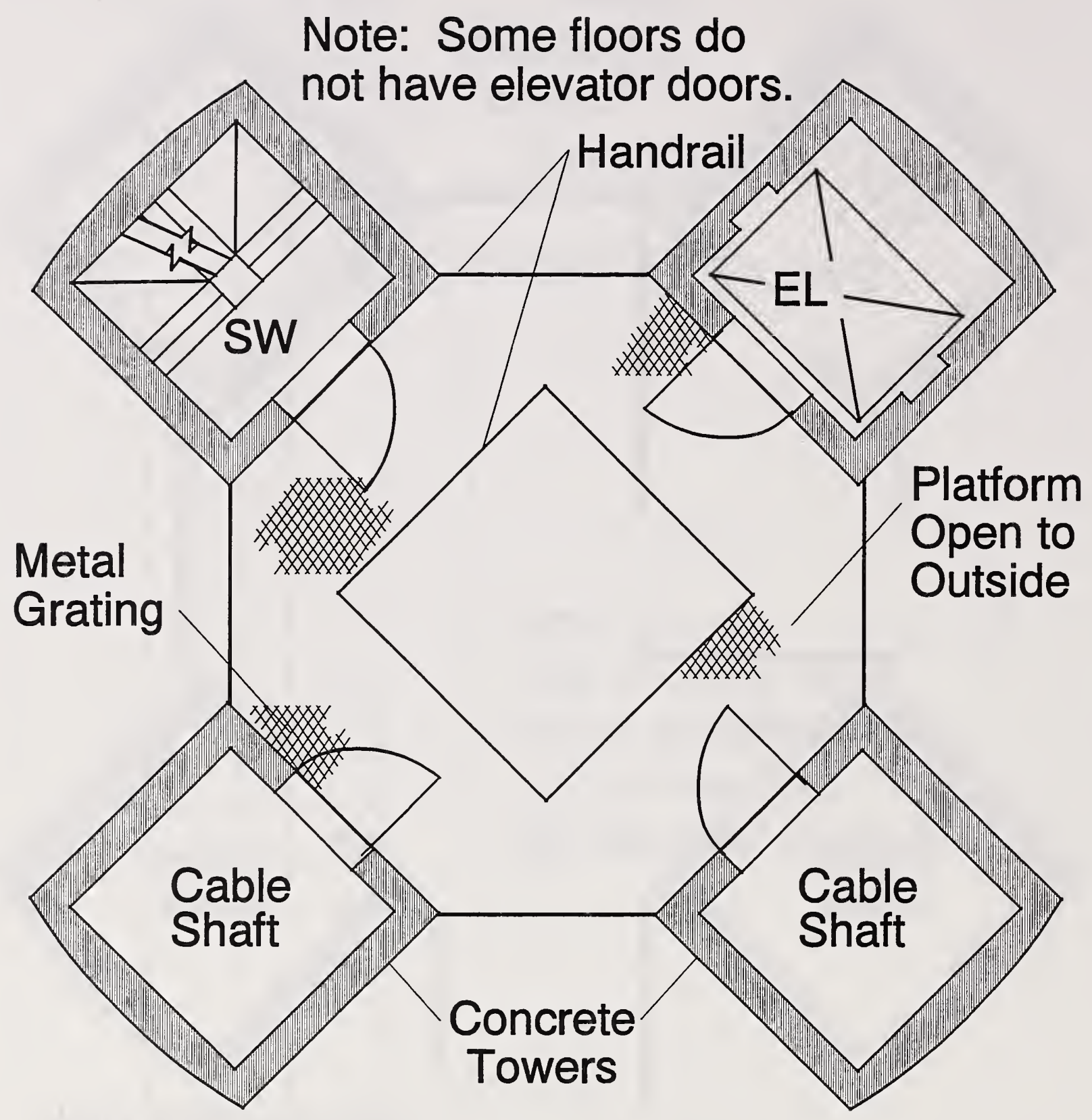

Figure 22. Typical floor of the Welton Becket standard design ATCT 


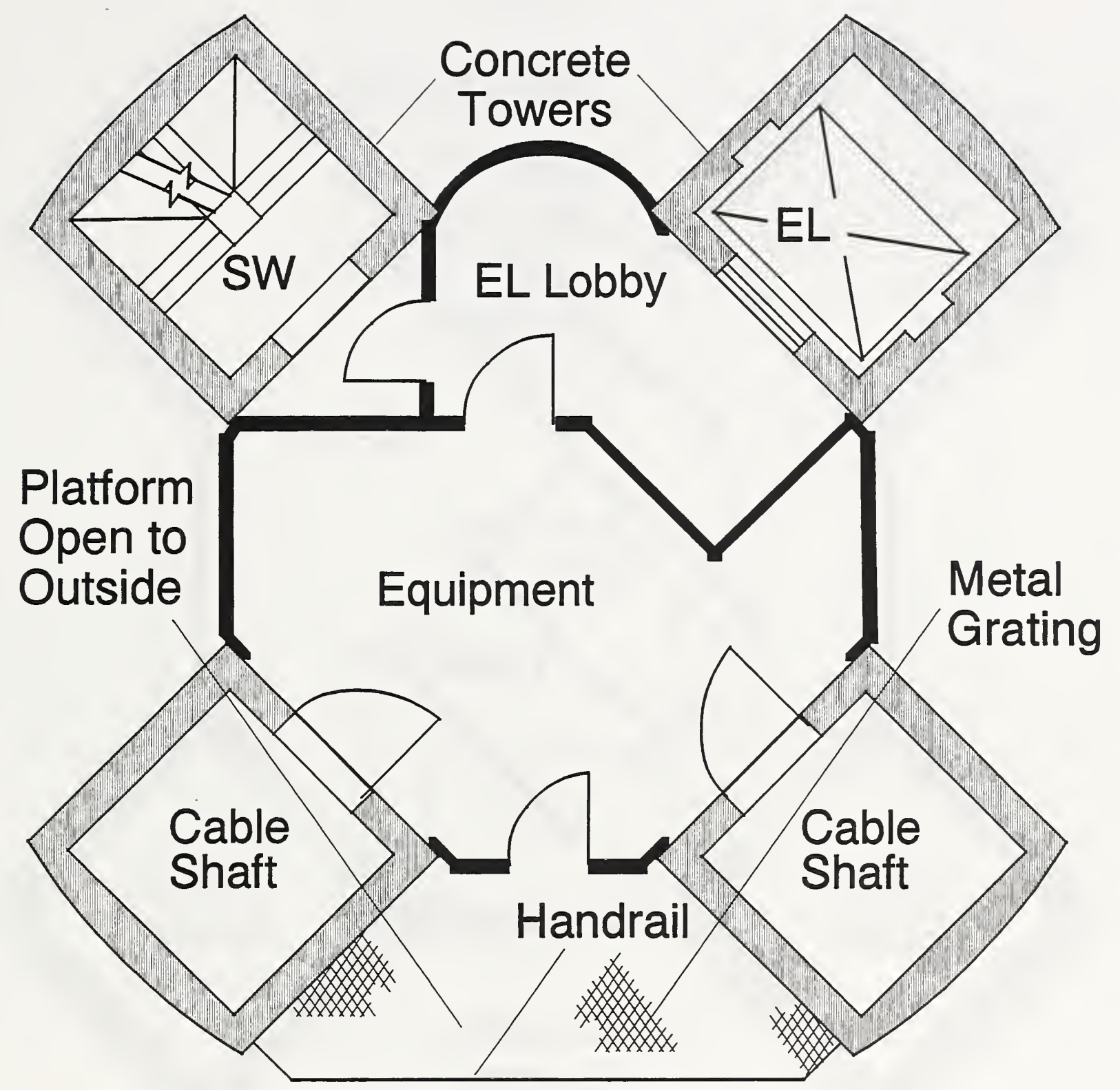

Figure 23. Subjunction floor of the Welton Becket standard design ATCT 


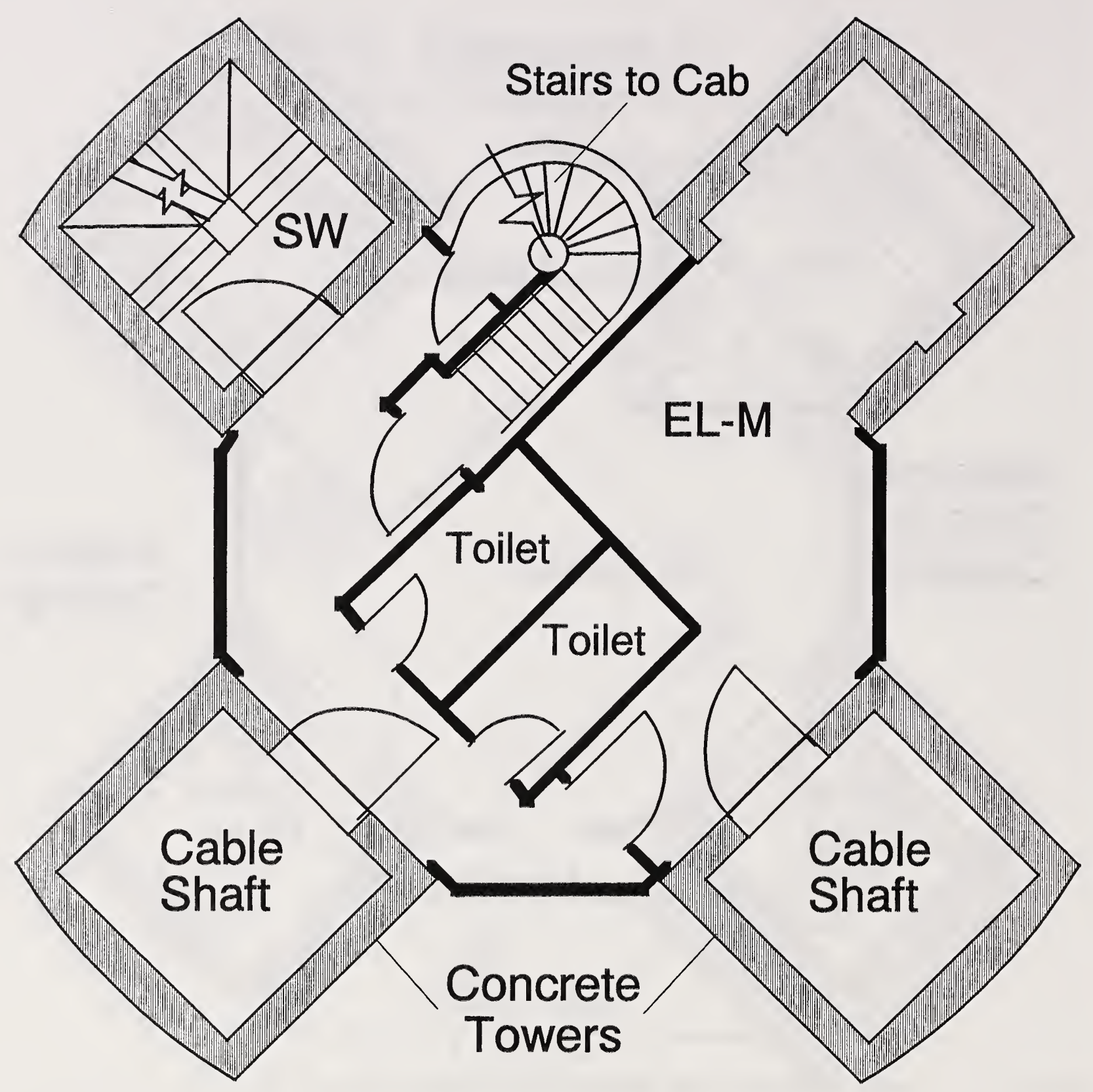

Figure 24. Junction floor of the Welton Becket standard design ATCT 


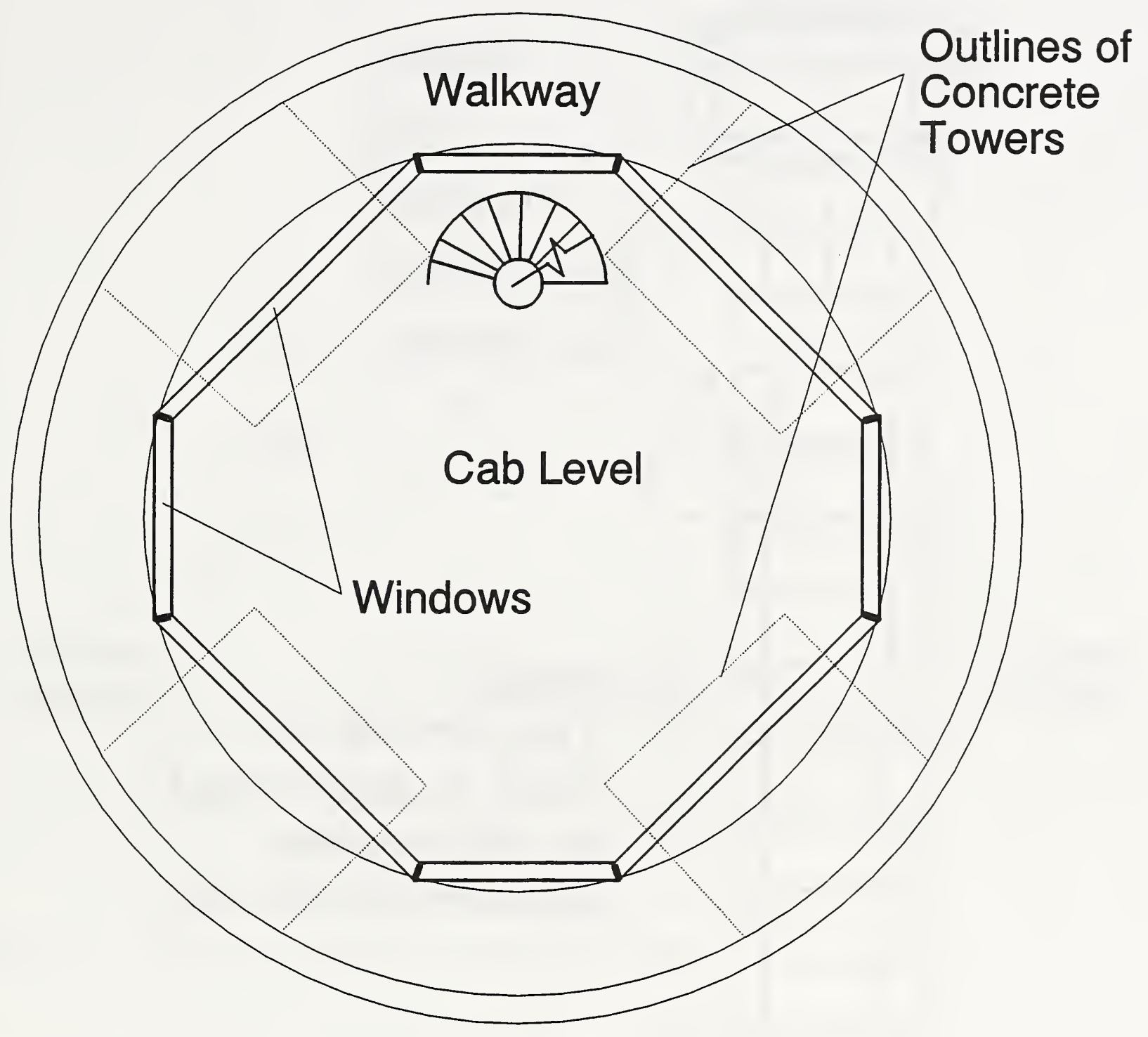

Figure 25. Cab floor of the Welton Becket standard design ATCT 


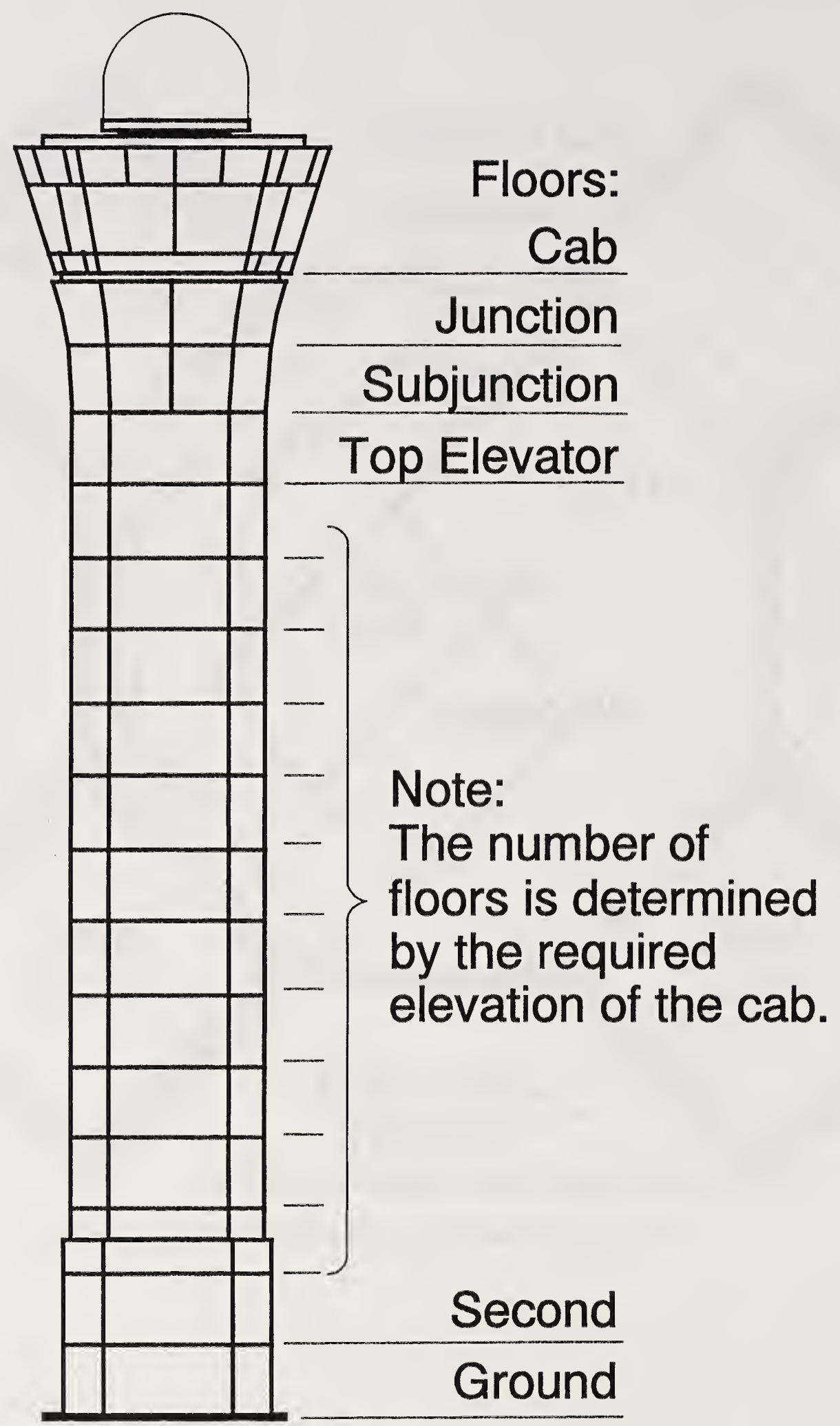

Figure 26. Elevation of the Pei standard design ATCT 


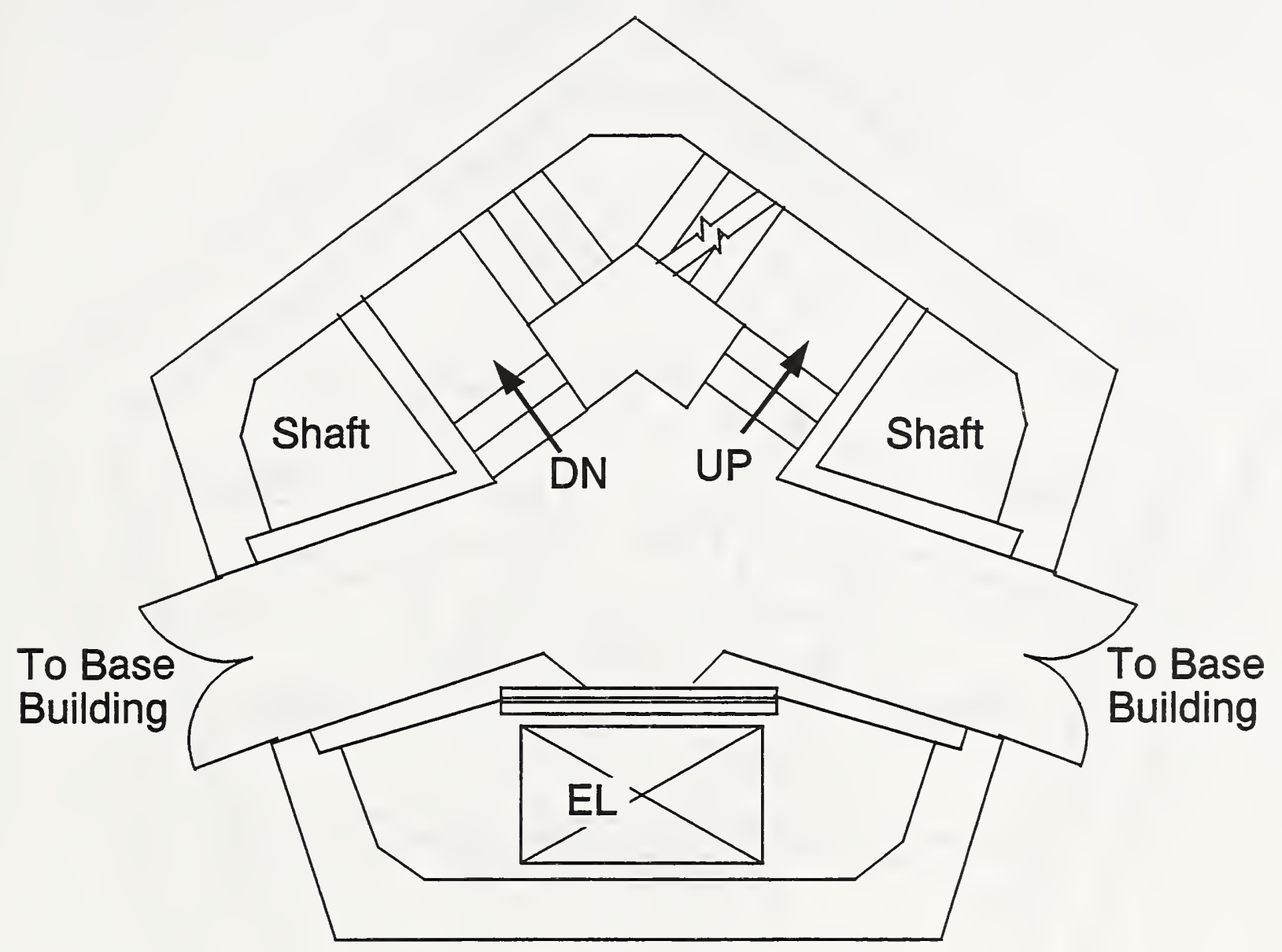

Figure 27. Ground floor of the Pei standard design ATCT 


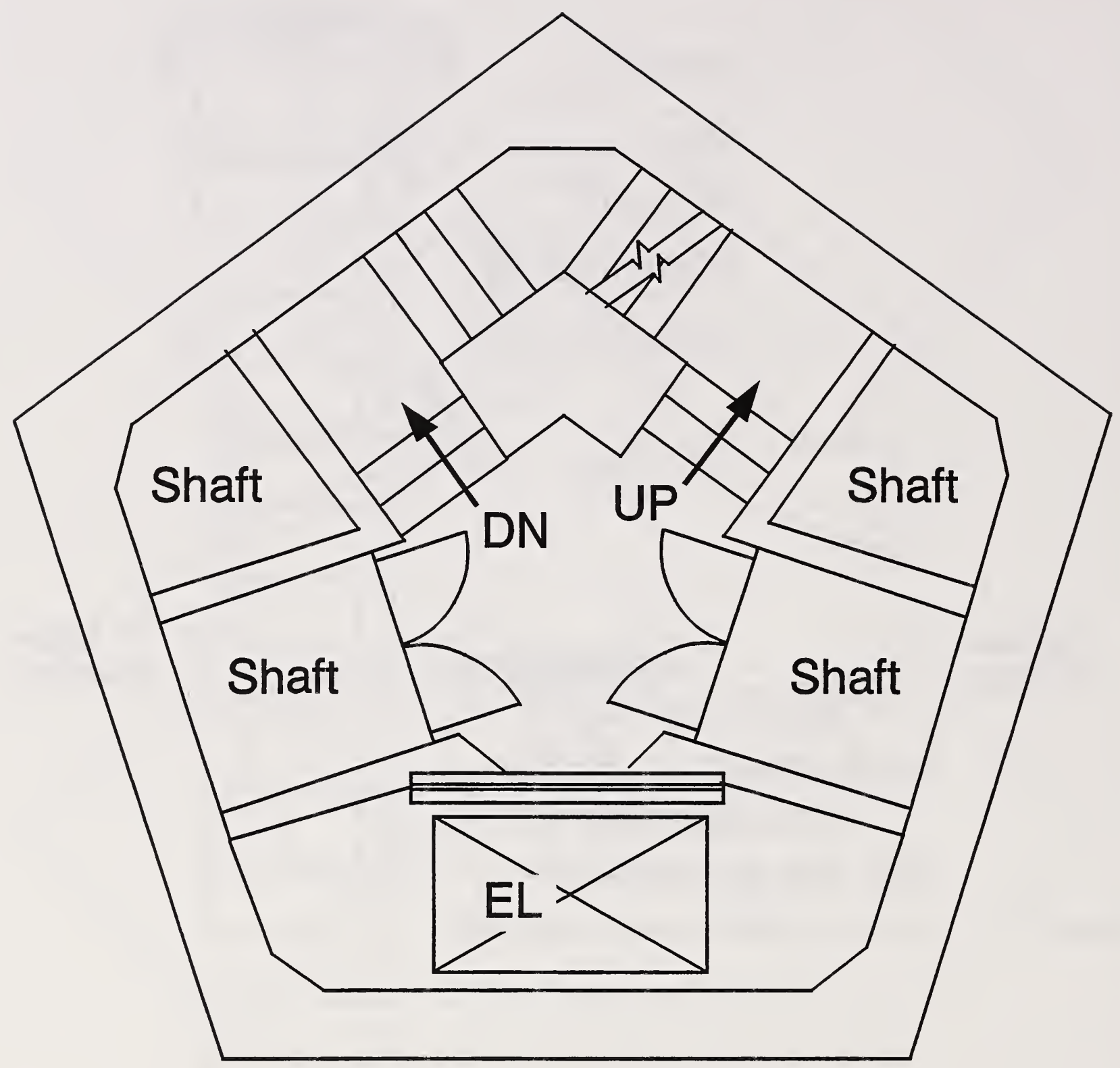

Figure 28. Typical floor of the Pei standard design ATCT 


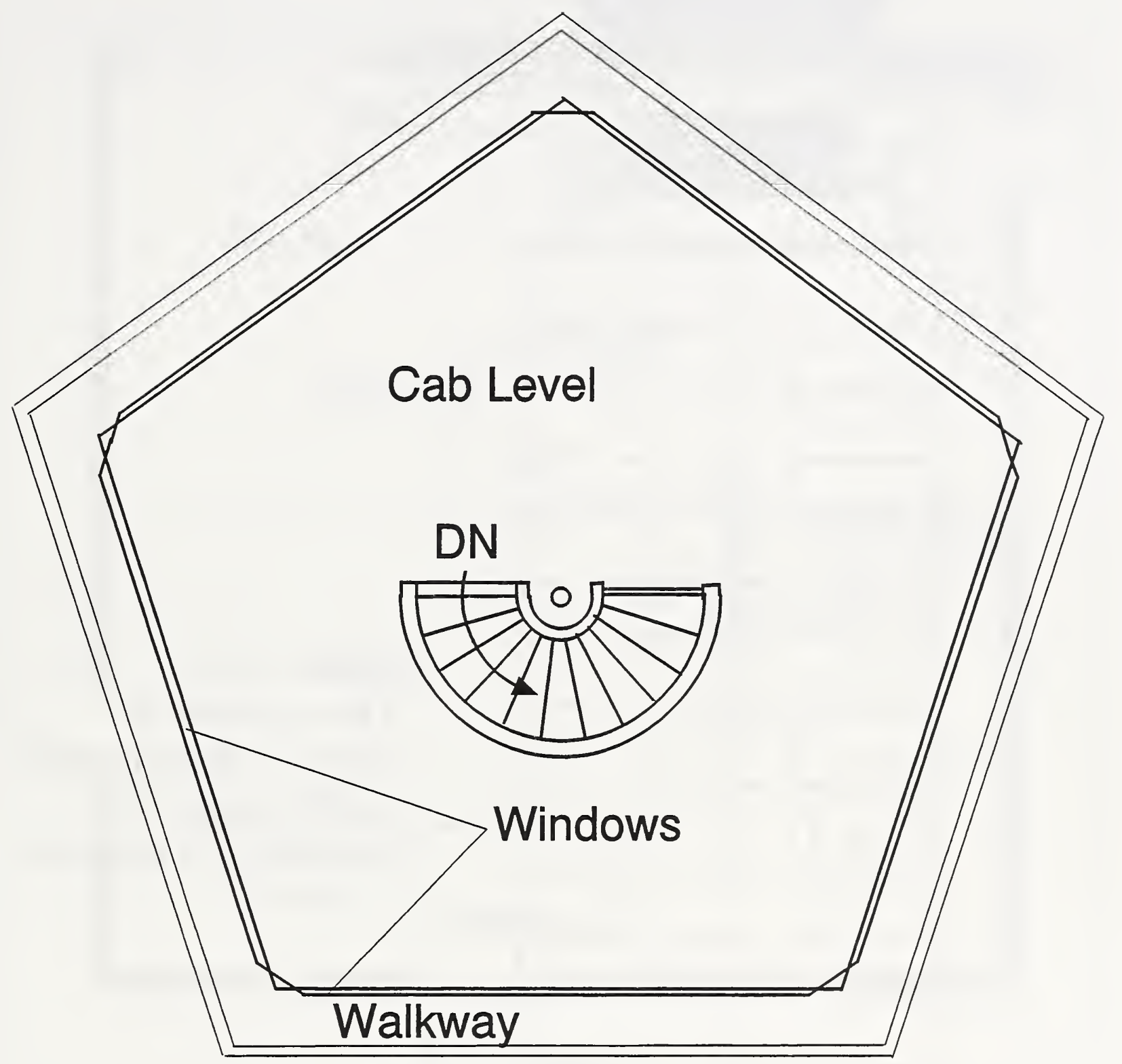

Figure 29. Cab floor of the Pei standard design ATCT 


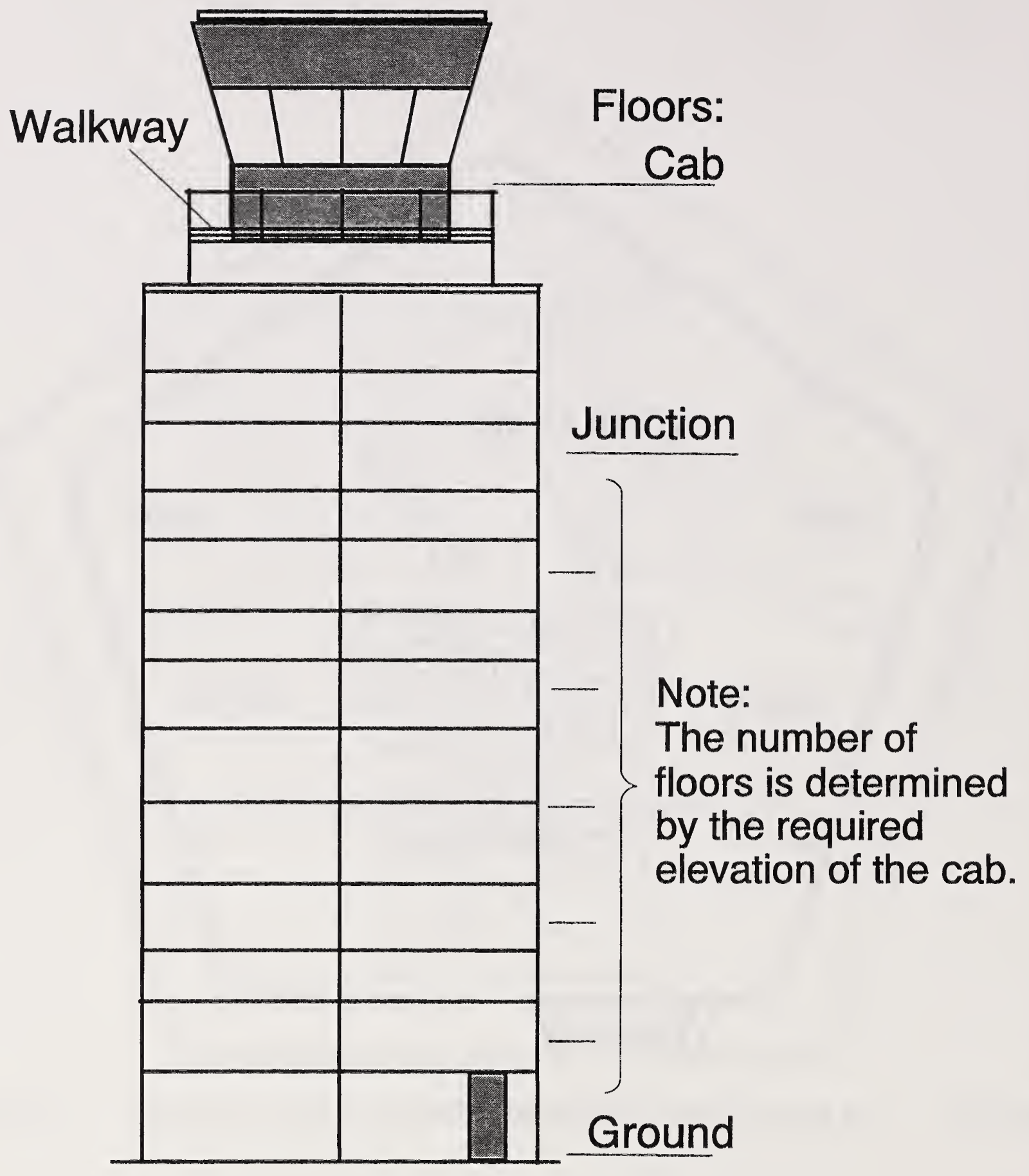

Figure 30. Elevation of the LART standard design ATCT 


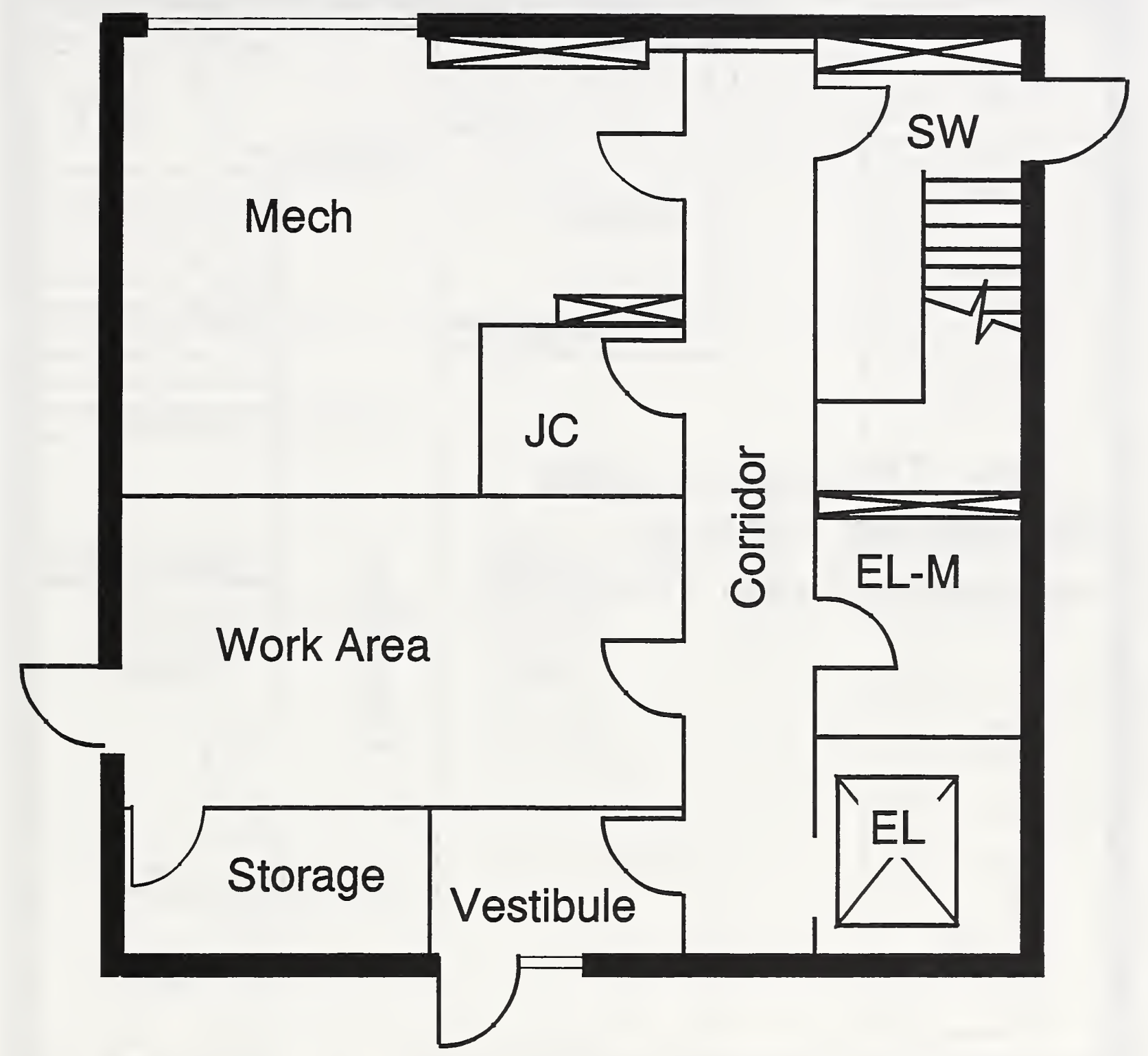

Figure 31. Ground floor of the LART standard design ATCT 


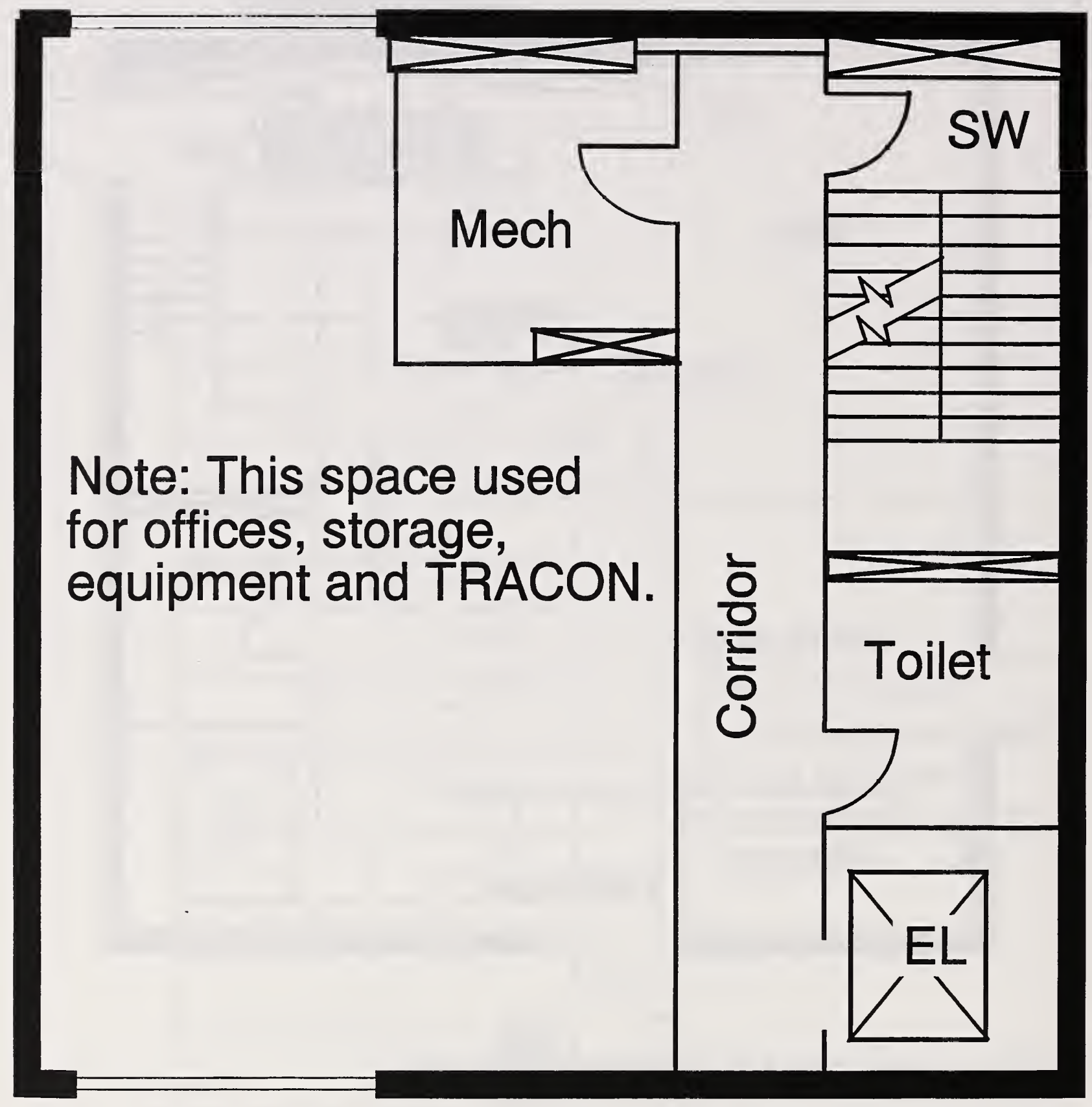

Figure 32. Typical floor of the LART standard design ATCT 


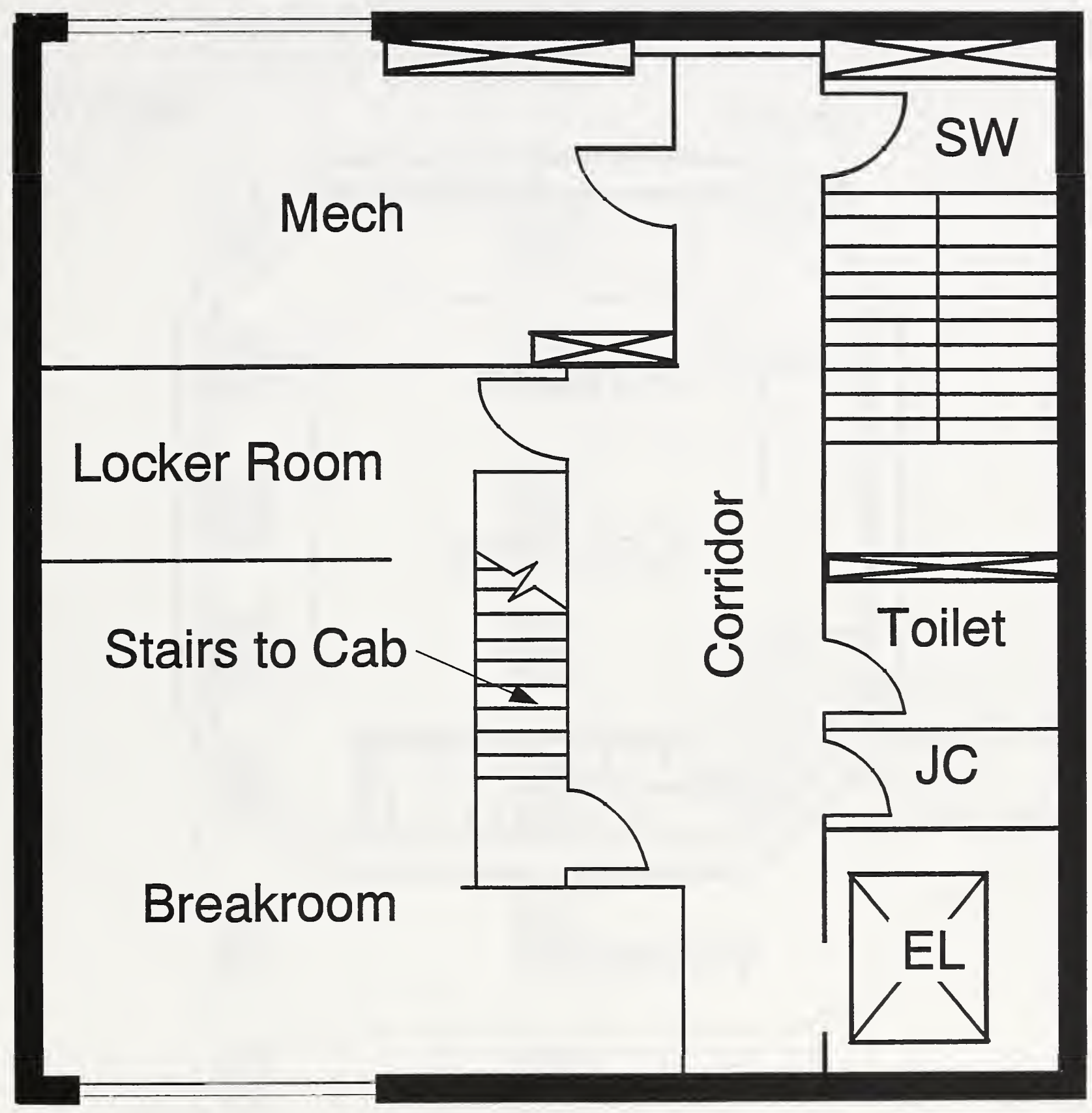

Figure 33. Junction floor of the LART standard design ATCT 


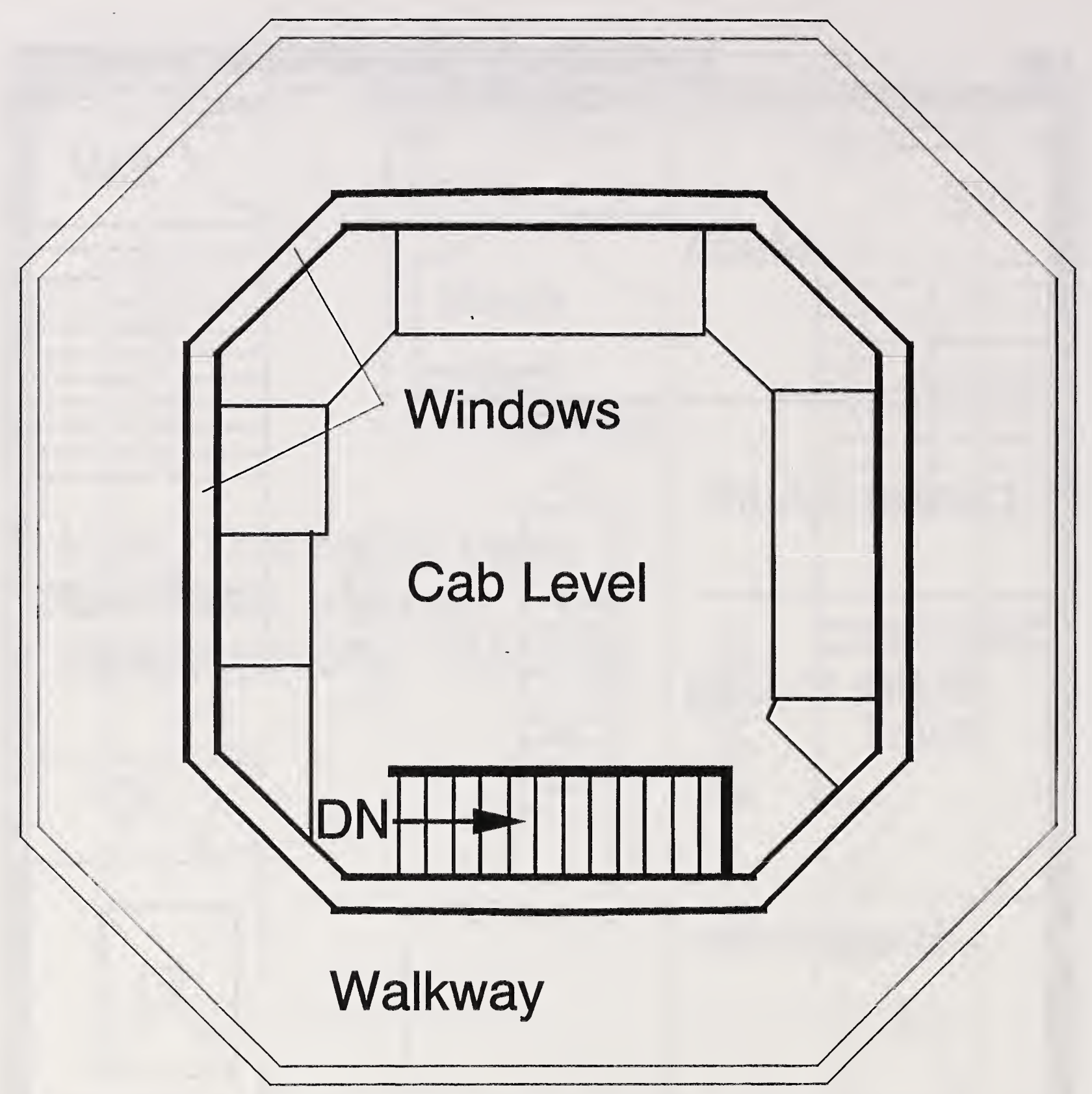

Figure 34. Cab floor of the LART standard design ATCT 


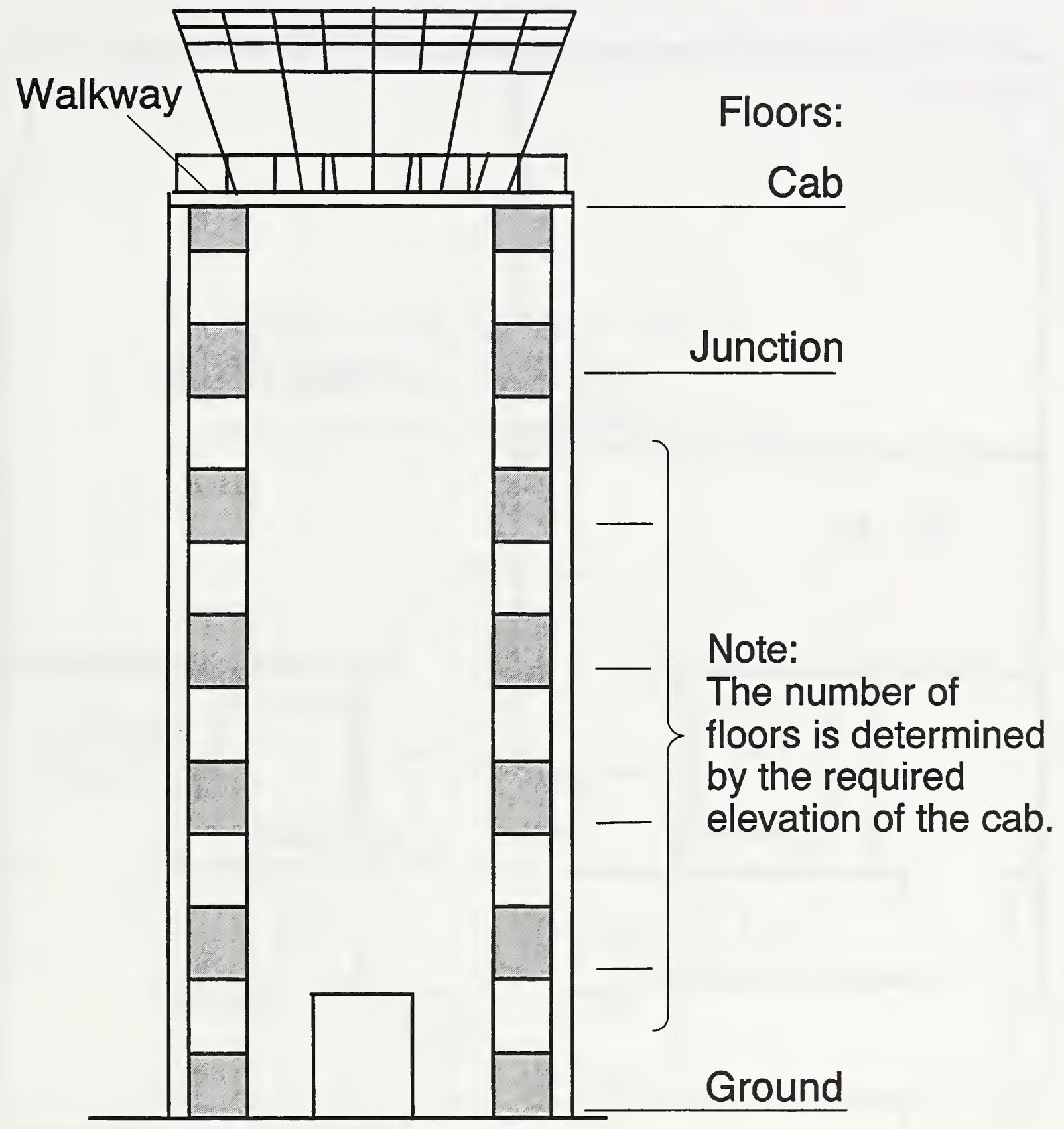

Figure 35. Elevation of the Mock standard design ATCT 


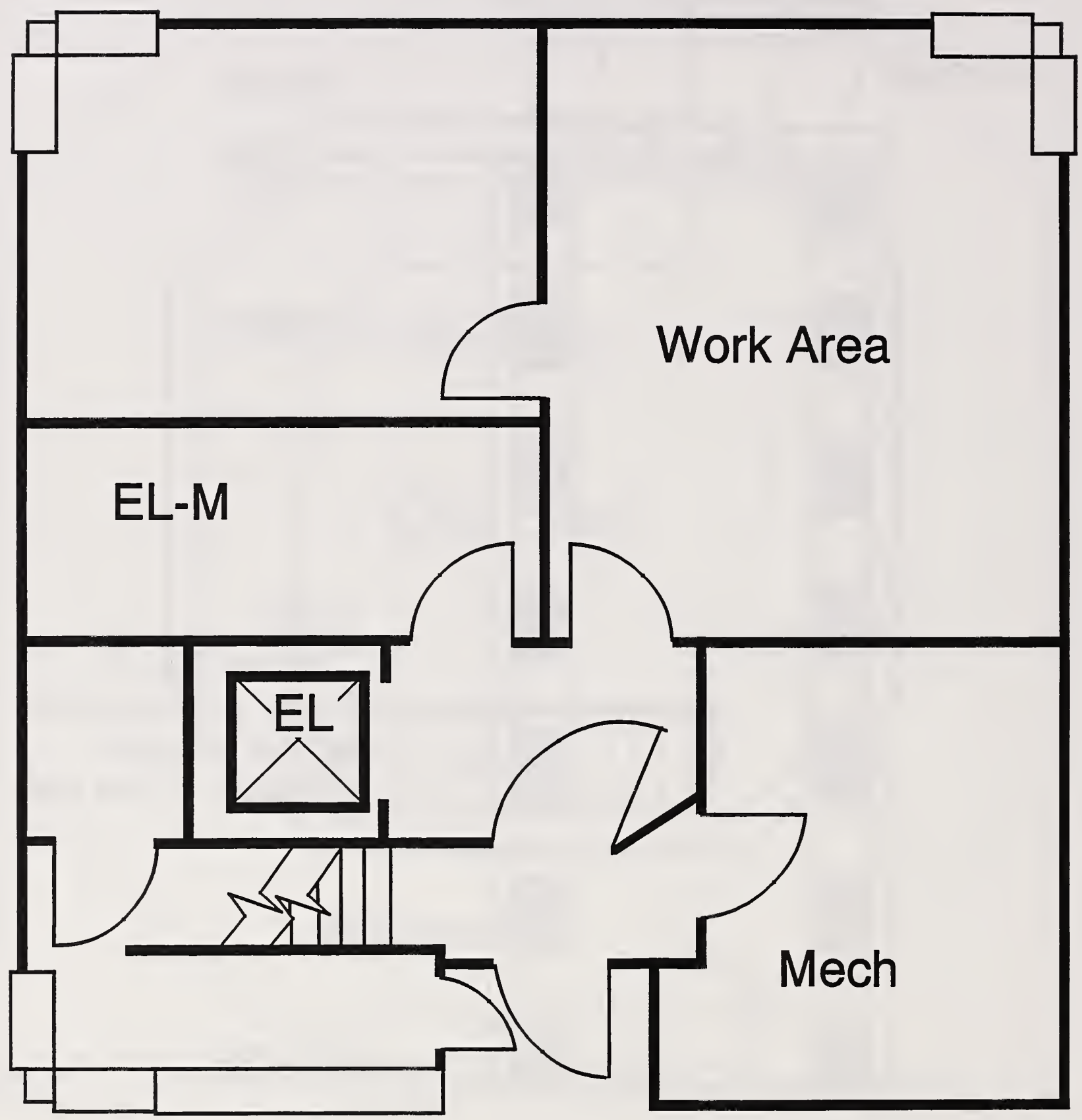

Figure 36. Ground floor of the Mock standard design ATCT 


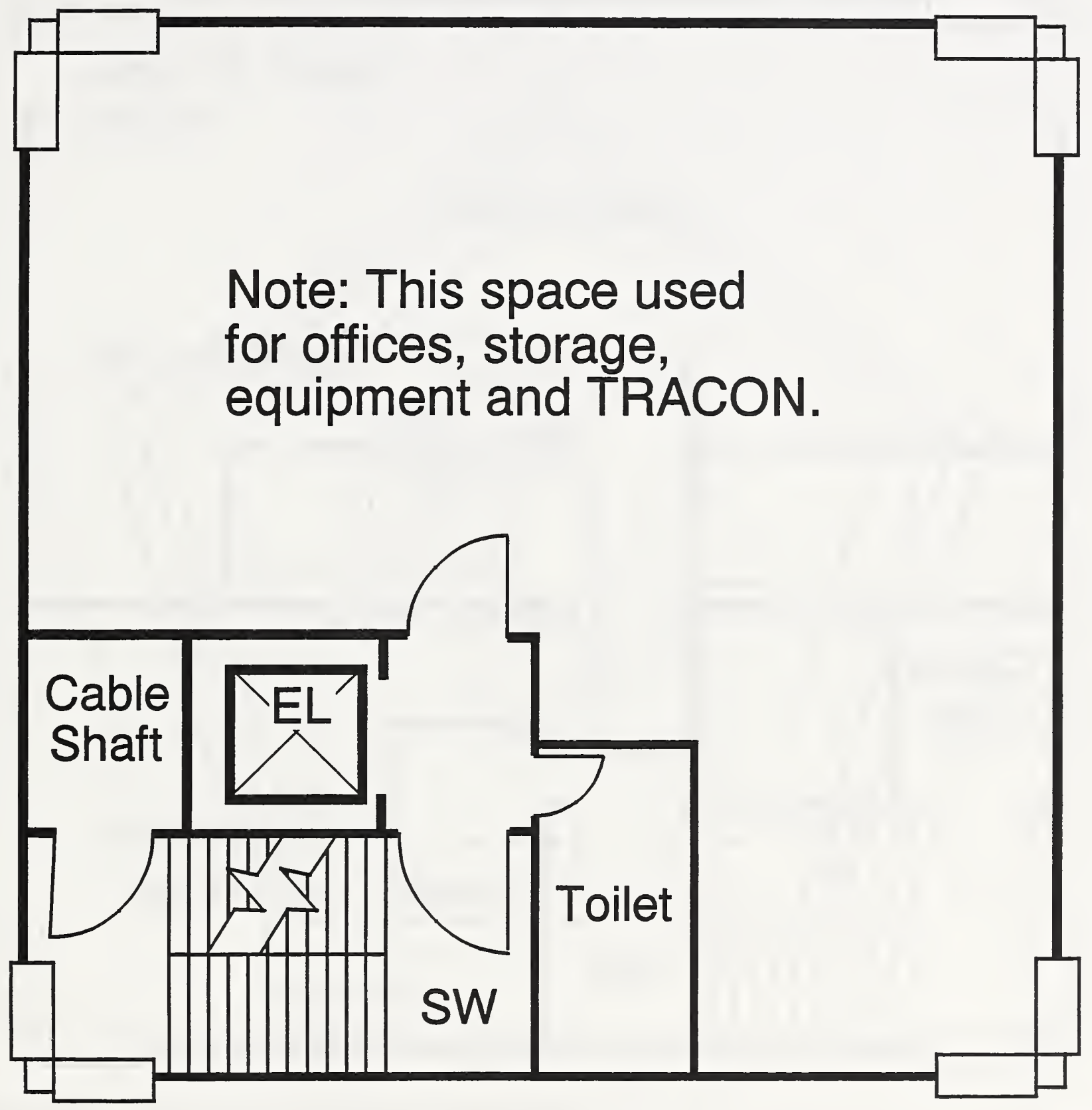

Figure 37. Typical floor of the Mock standard design ATCT 


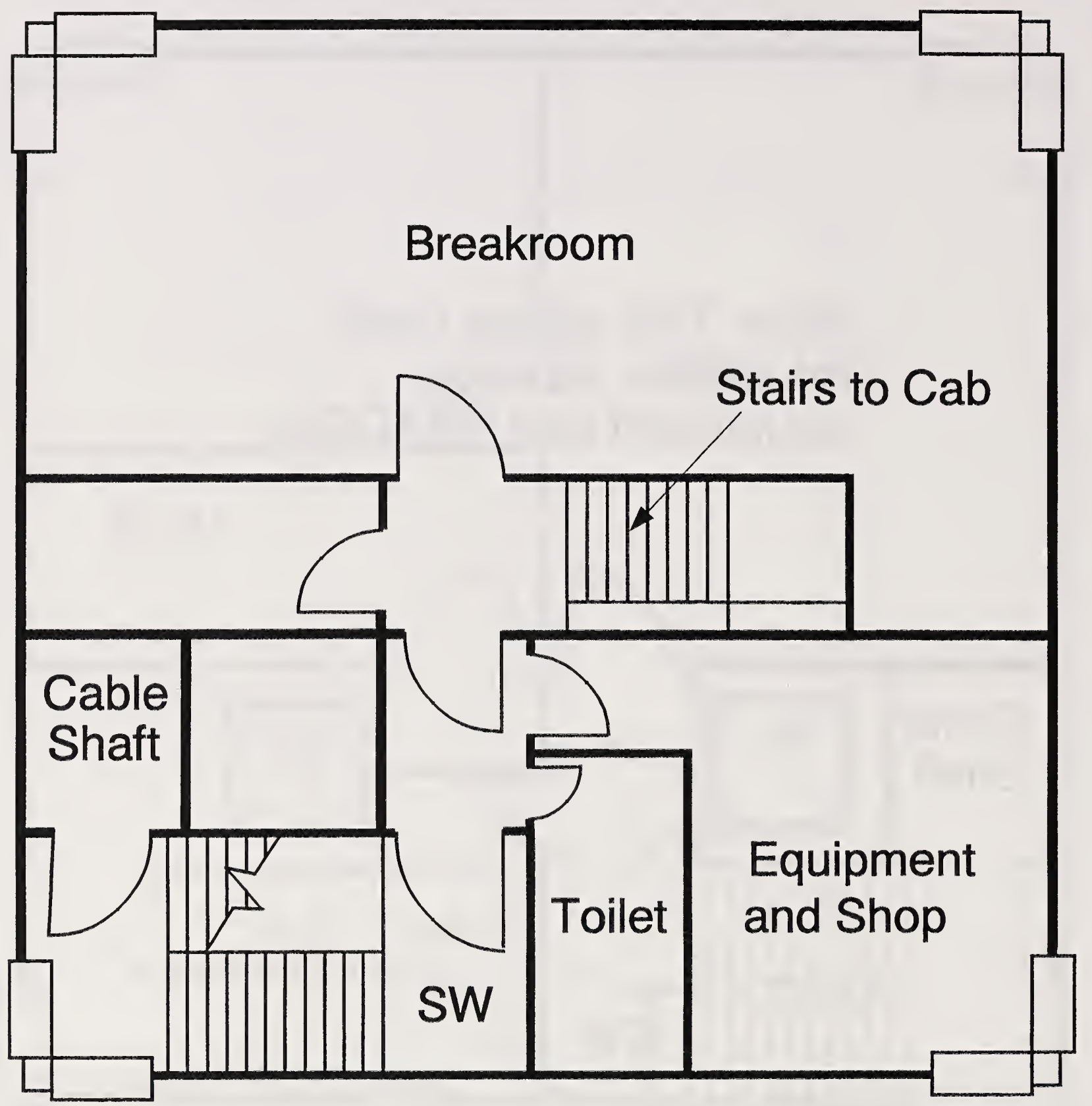

Figure 38. Junction floor of the Mock standard design ATCT 


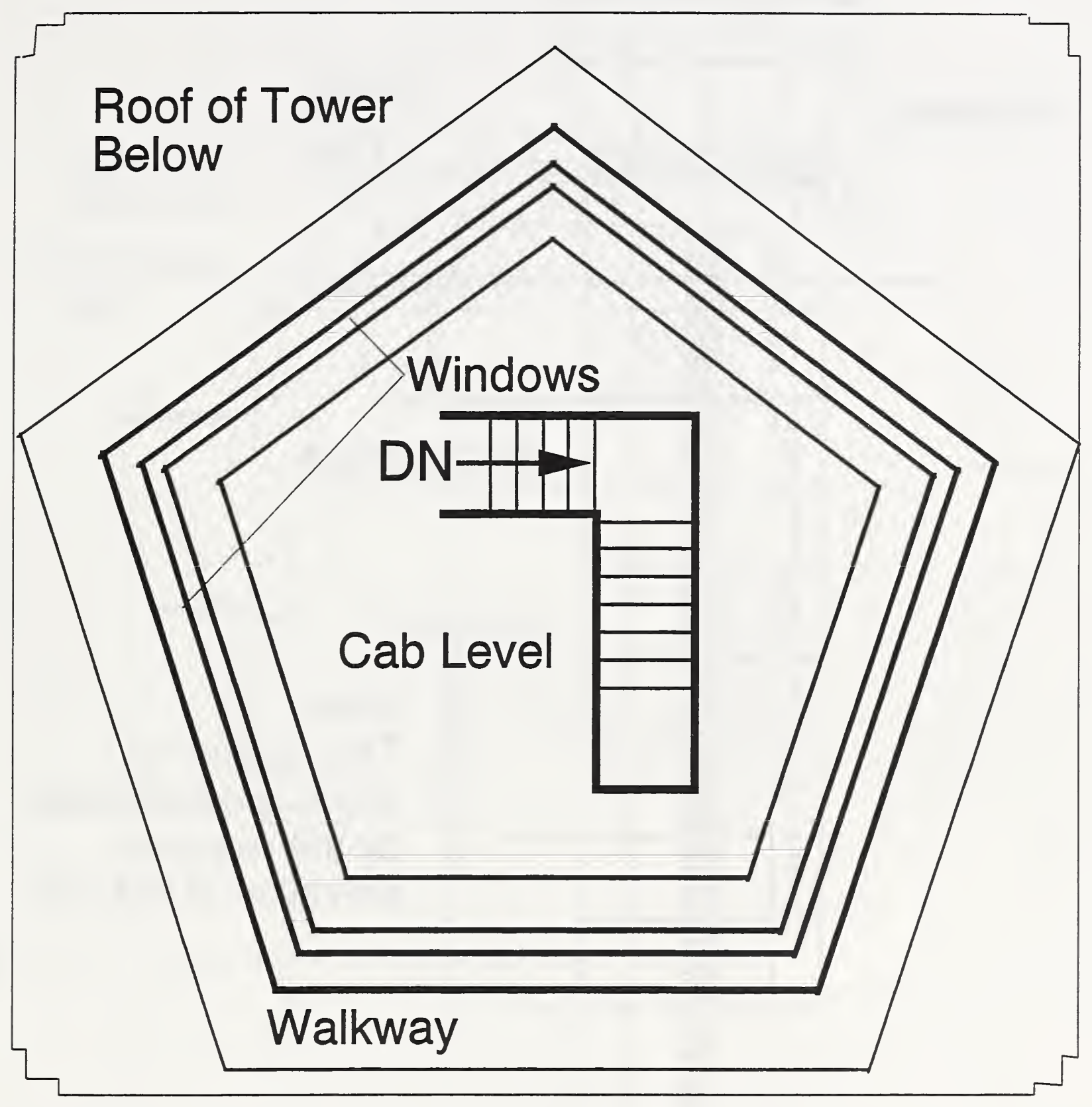

Figure 39. Cab floor of the Mock standard design ATCT 


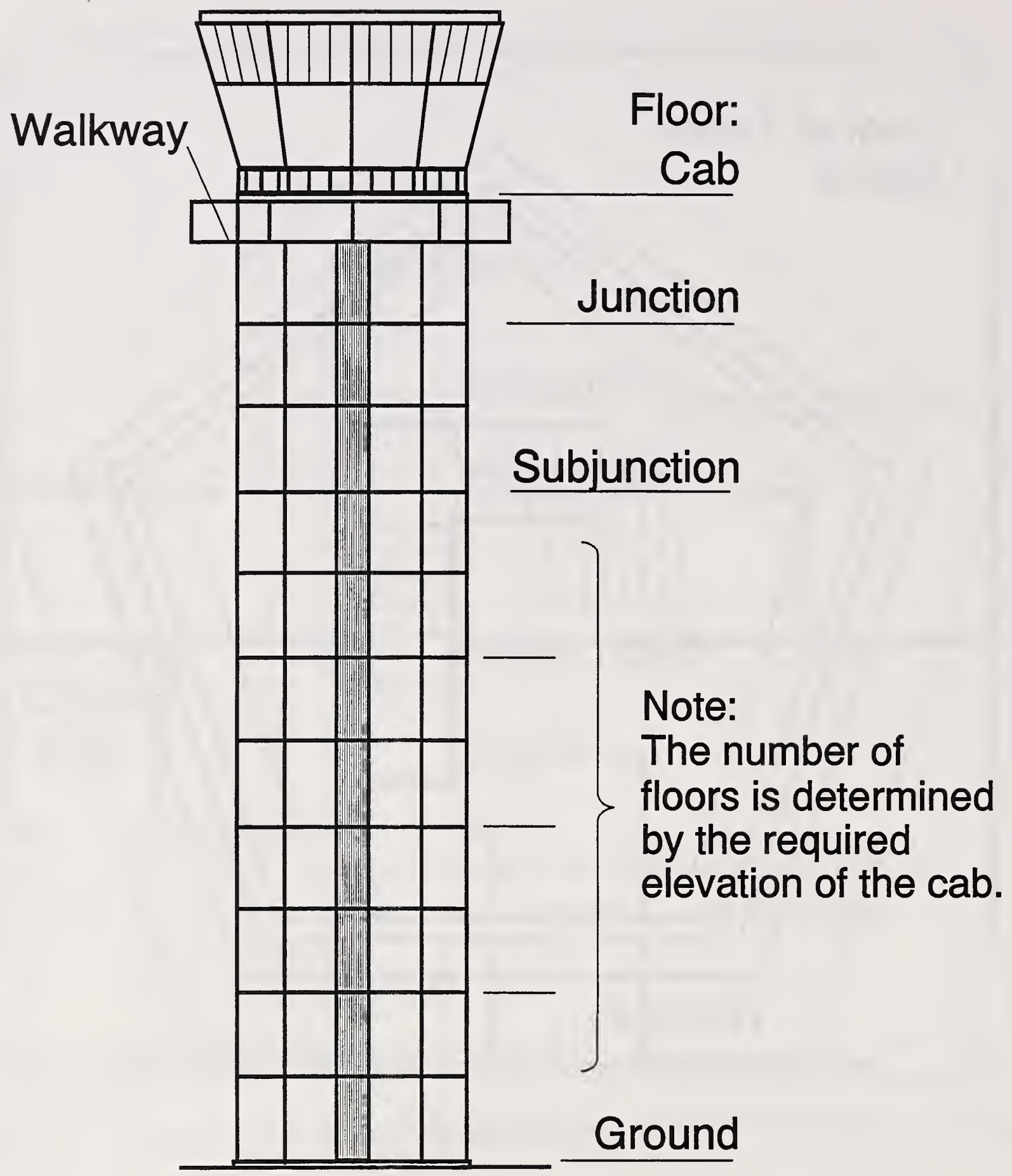

Figure 40. Elevation of the Golman Rolf standard design ATCT 


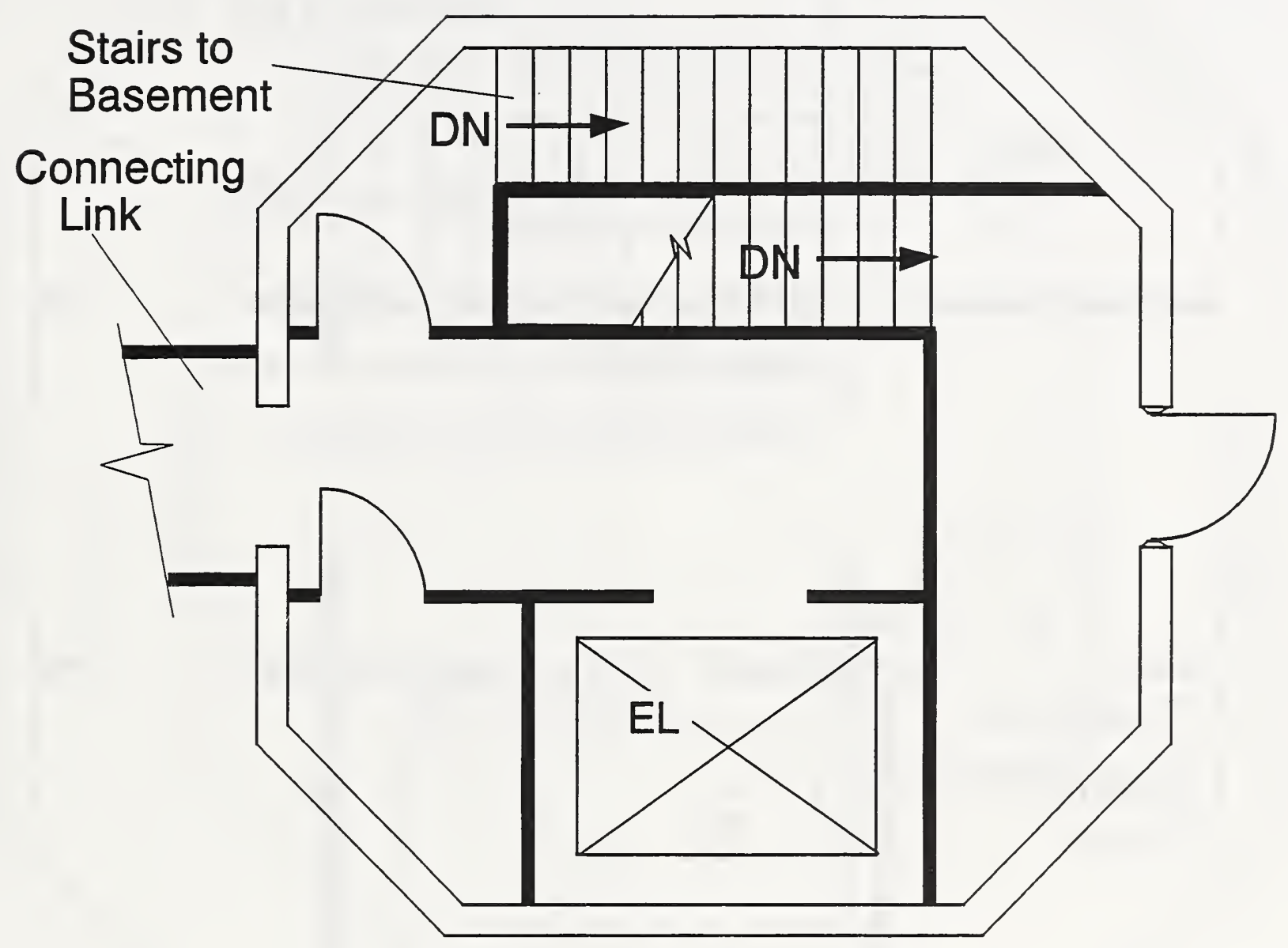

Figure 41. Ground floor of the Golman Rolf standard design ATCT 


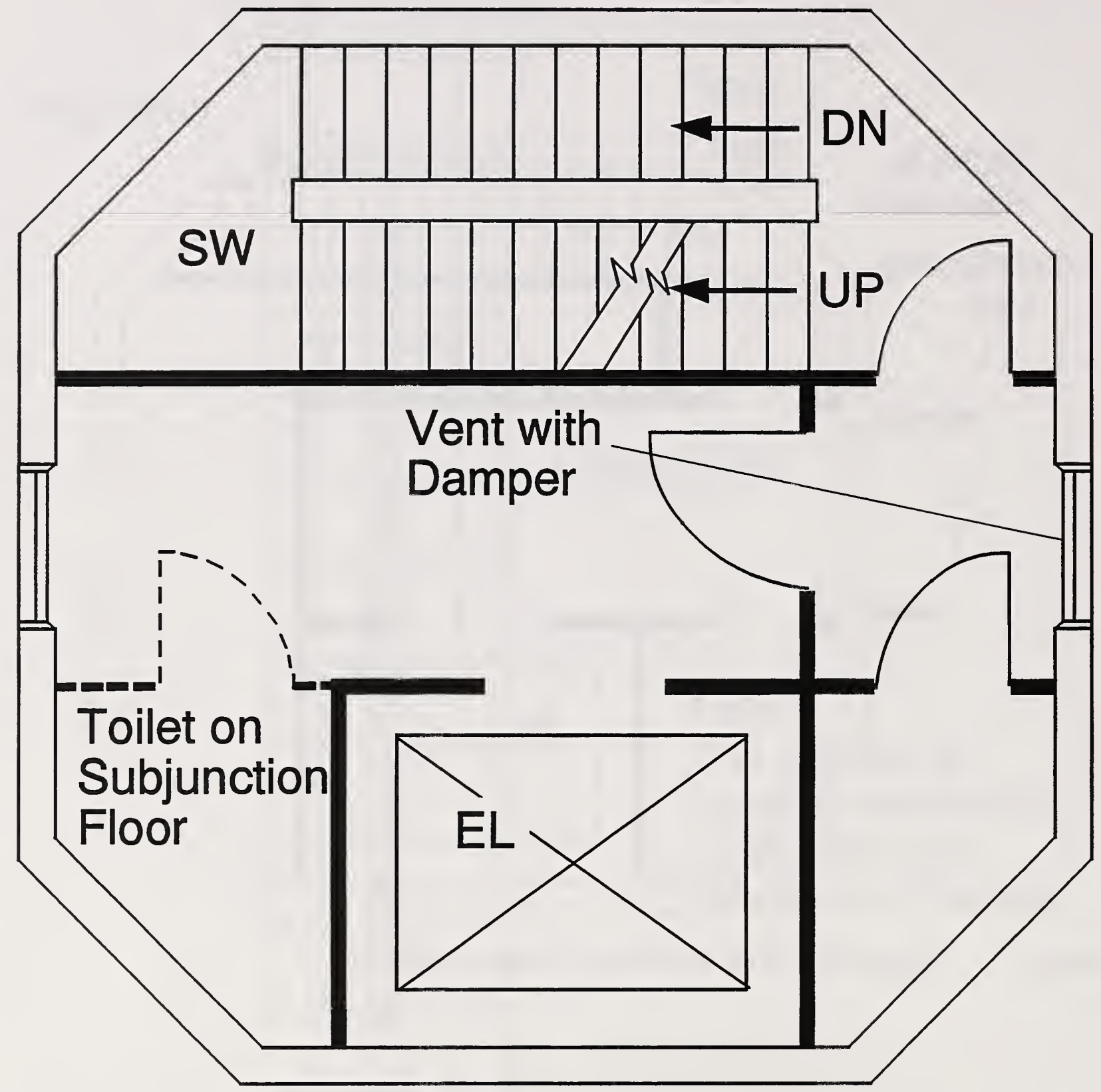

Figure 42. Typical floor of the Golman Rolf standard design ATCT 


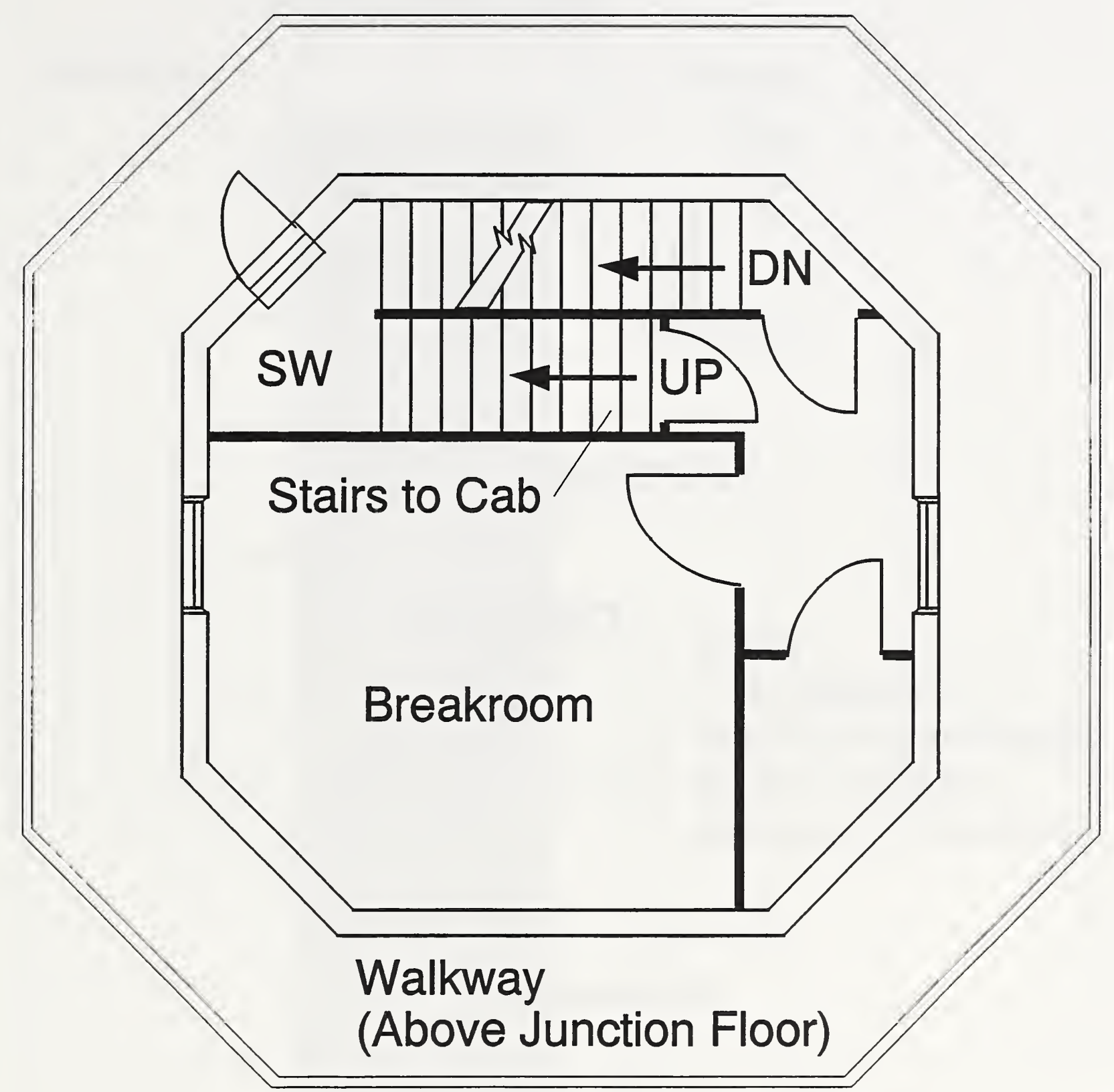

Figure 43. Junction floor of the Golman Rolf standard design ATCT 


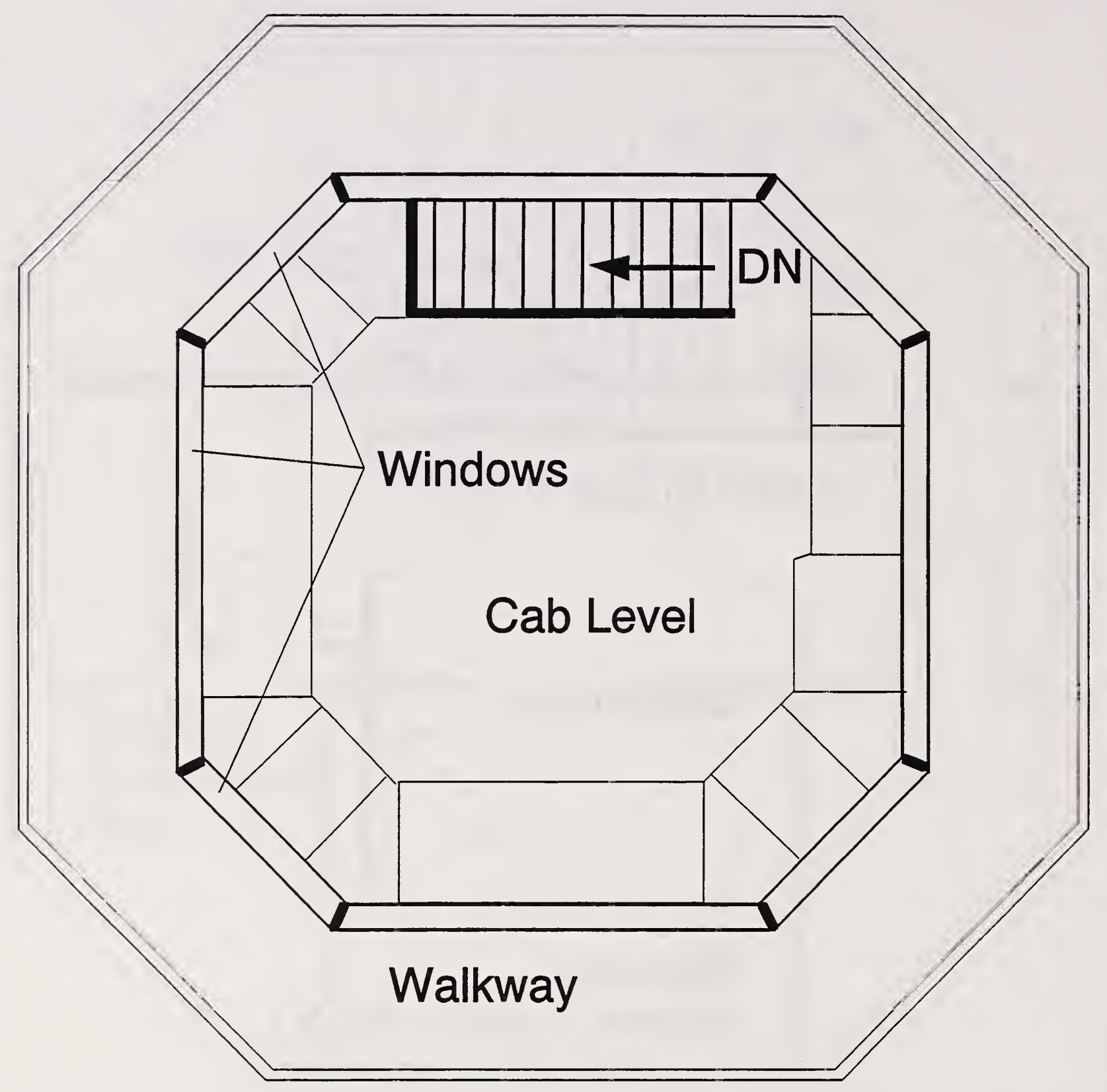

Figure 44. Cab floor of the Golman Rolf standard design ATCT 


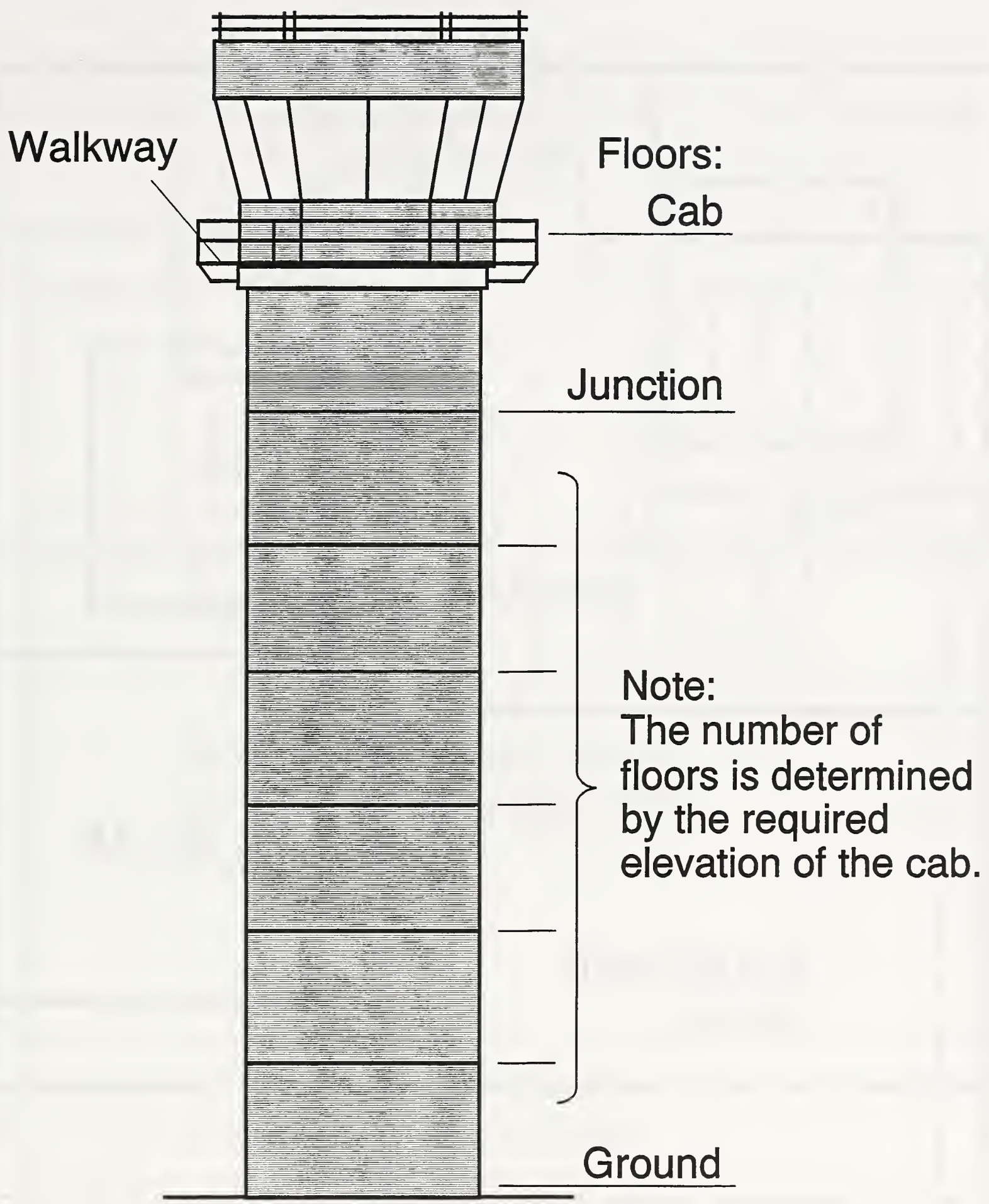

Figure 45. Elevation of the AVCO standard design ATCT 


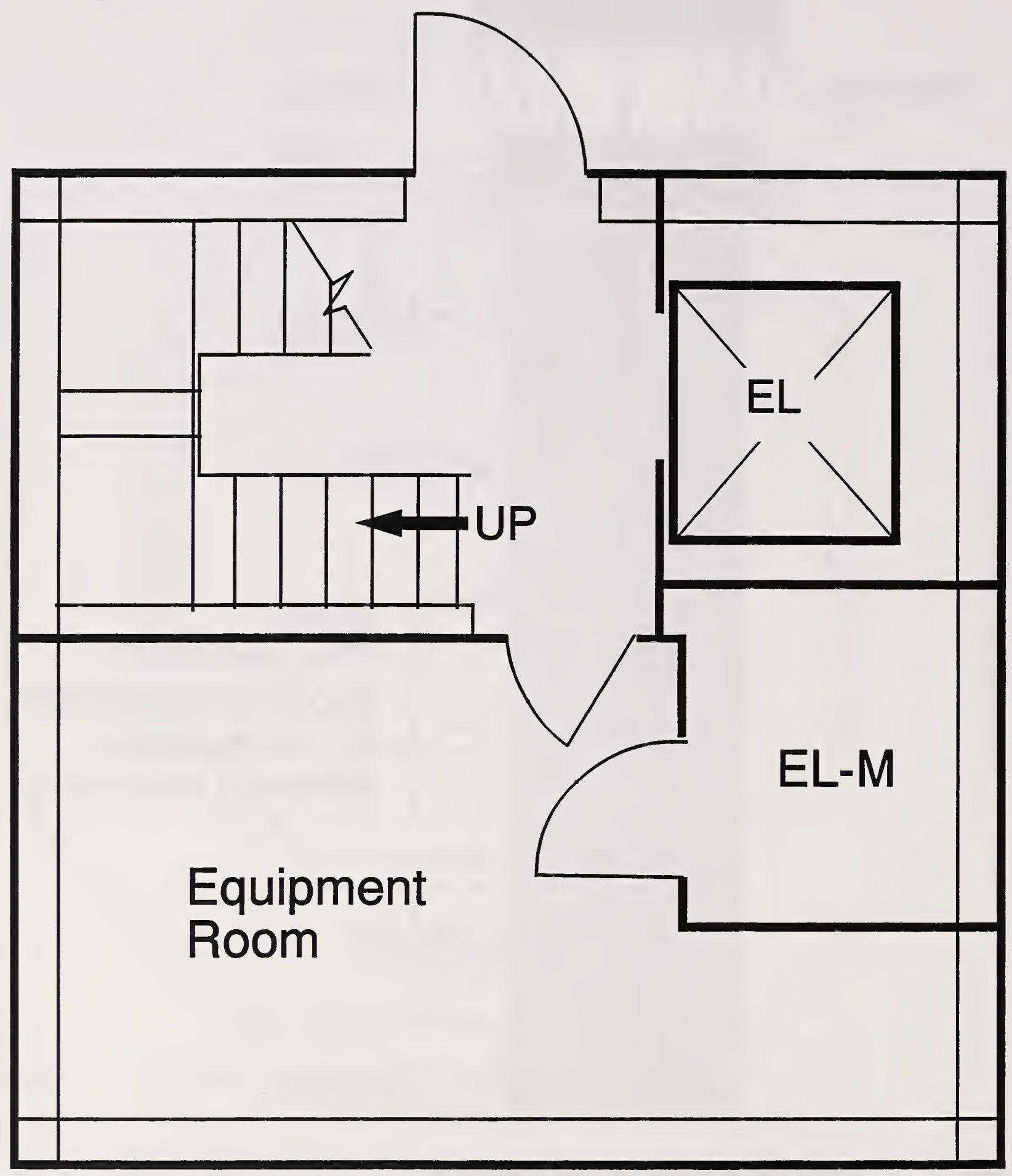

Figure 46. Ground floor of the AVCO standard design ATCT 


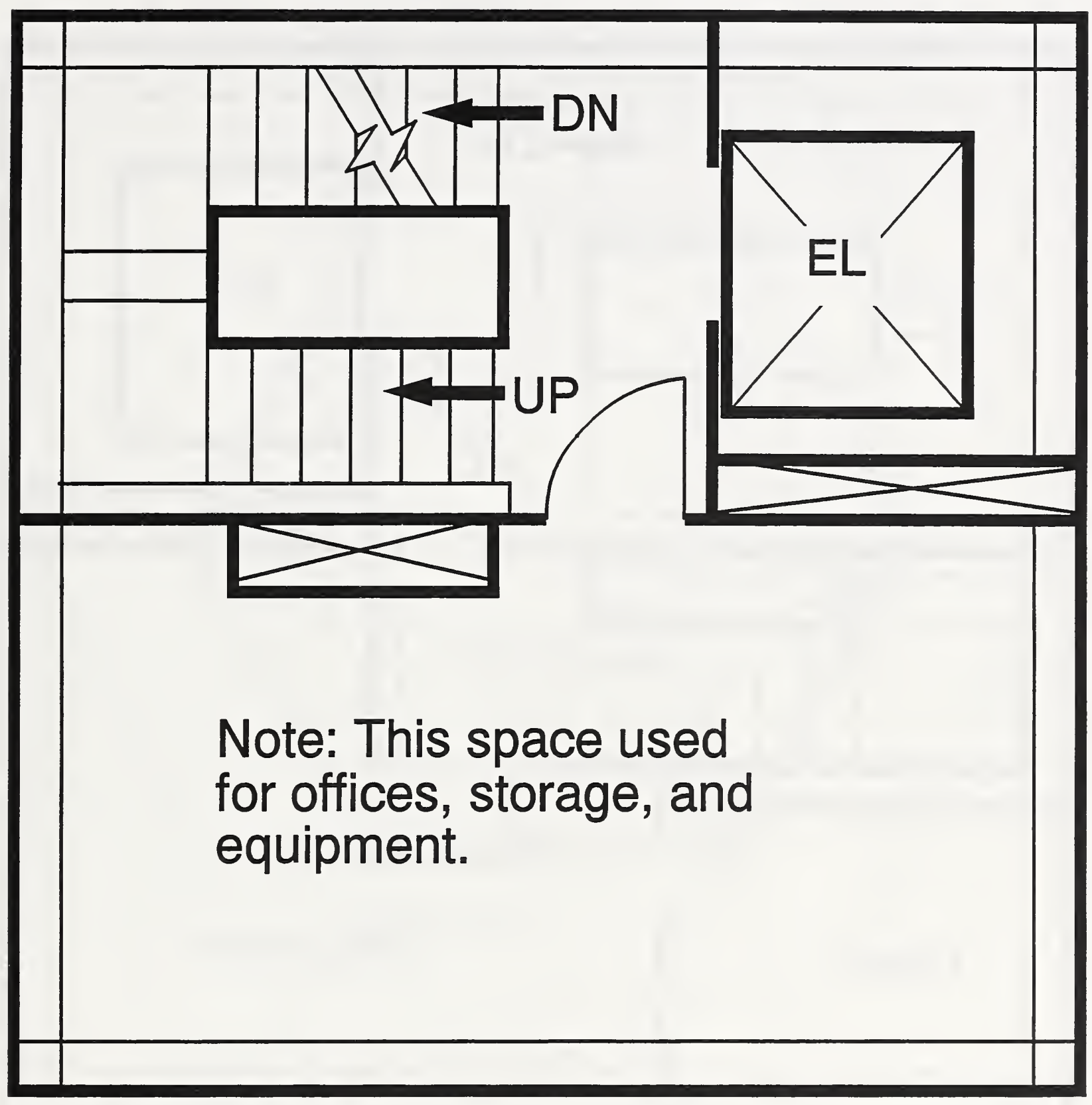

Figure 47. Typical floor of the AVCO standard design ATCT 


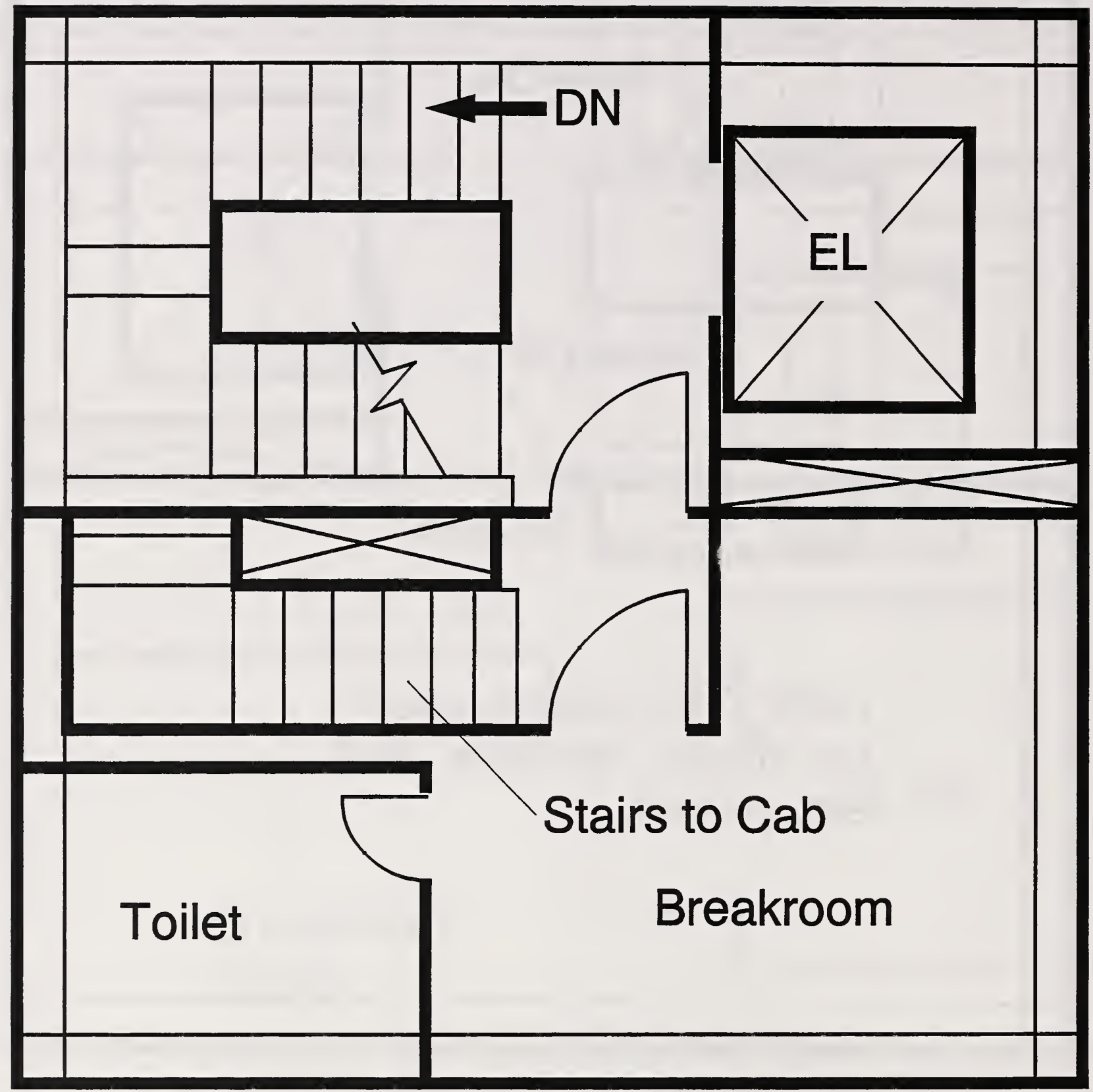

Figure 48. Junction floor of the AVCO standard design ATCT 


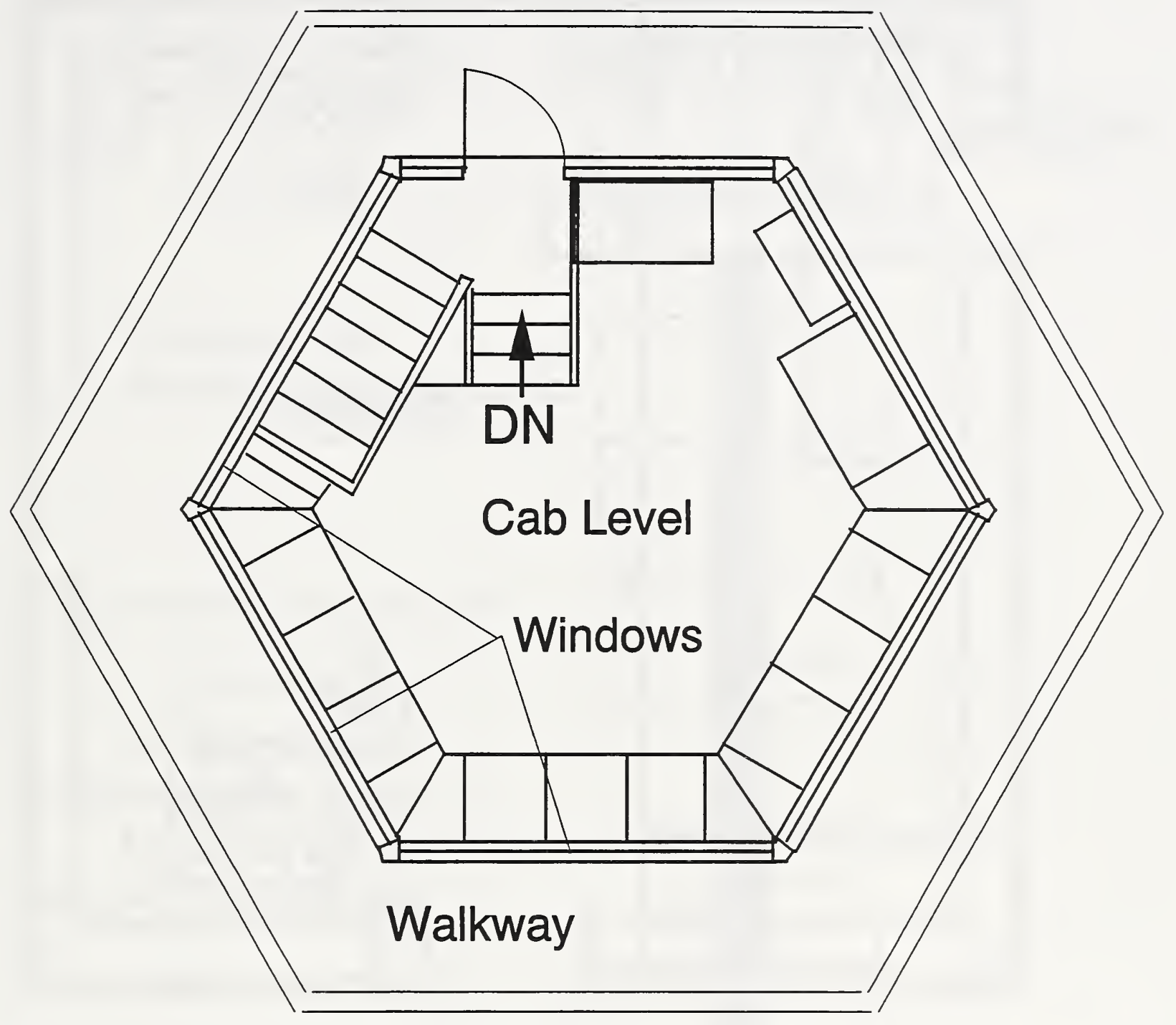

Figure 49. Cab floor of the AVCO standard design ATCT 


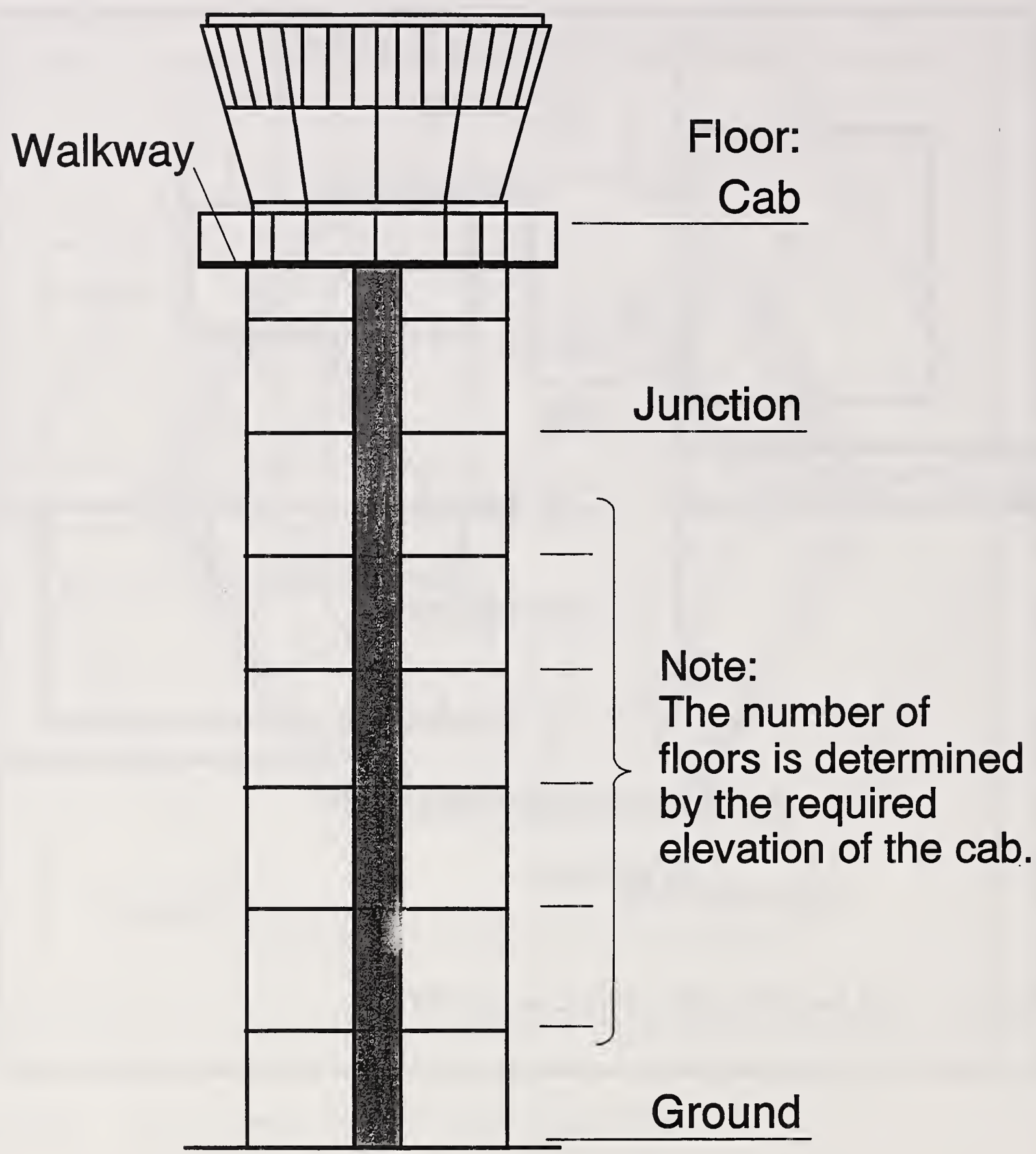

Figure 50. Elevation of the Leo Daly Low Activity standard design ATCT 


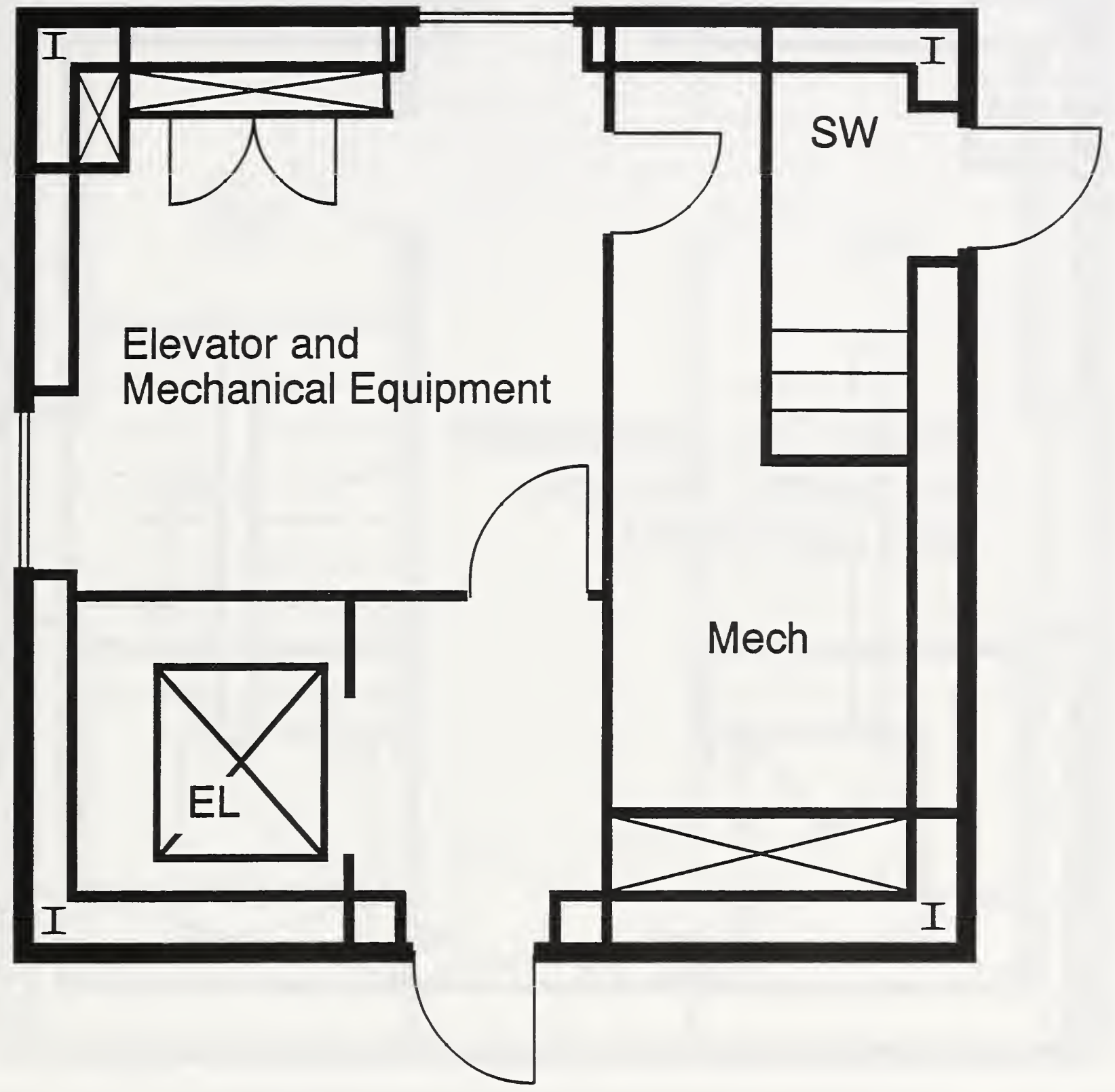

Figure 51. Ground floor of the Leo Daly Low Activity standard design ATCT 


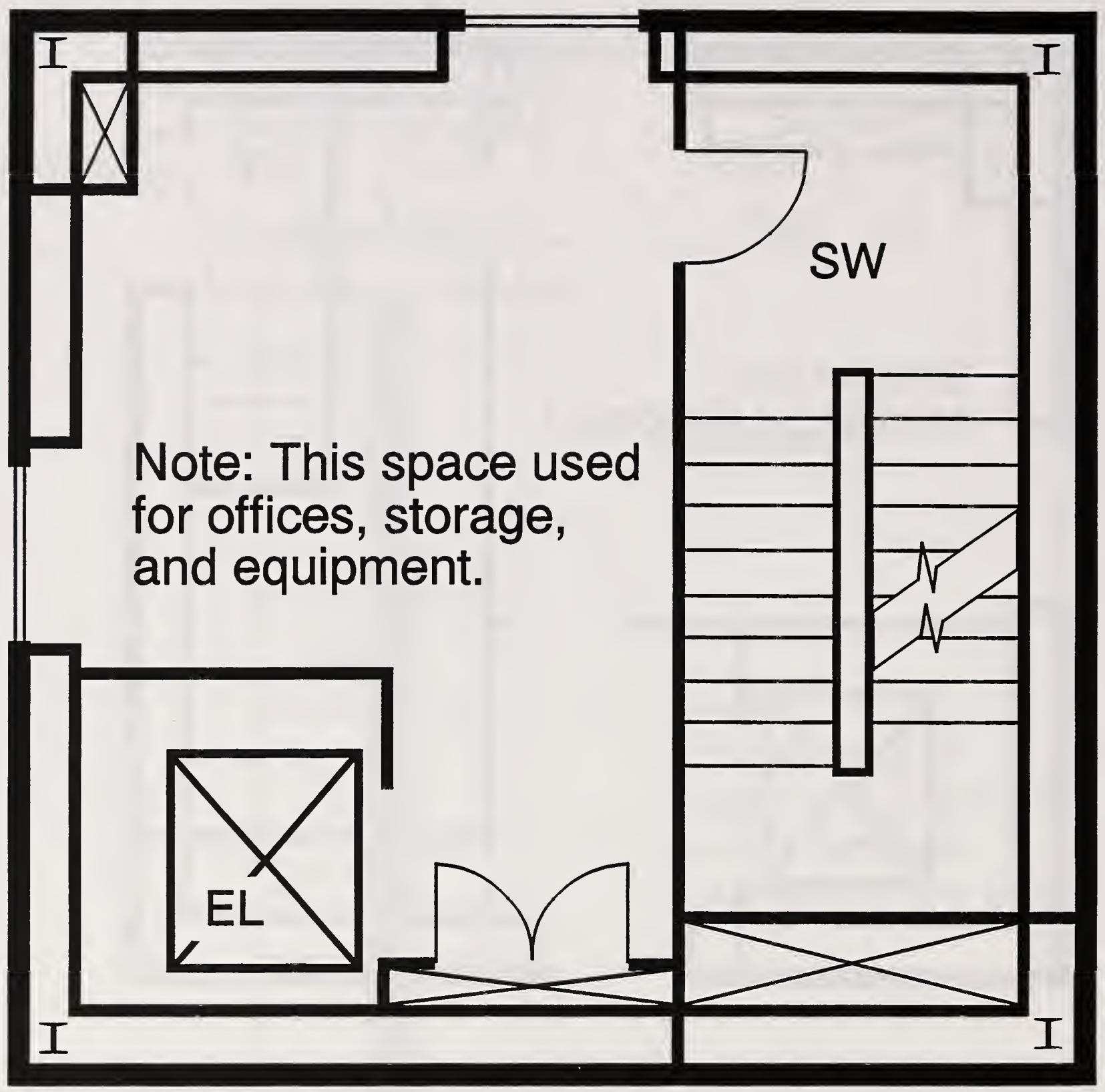

Figure 52. Typical floor of the Leo Daly Low Activity standard design ATCT 


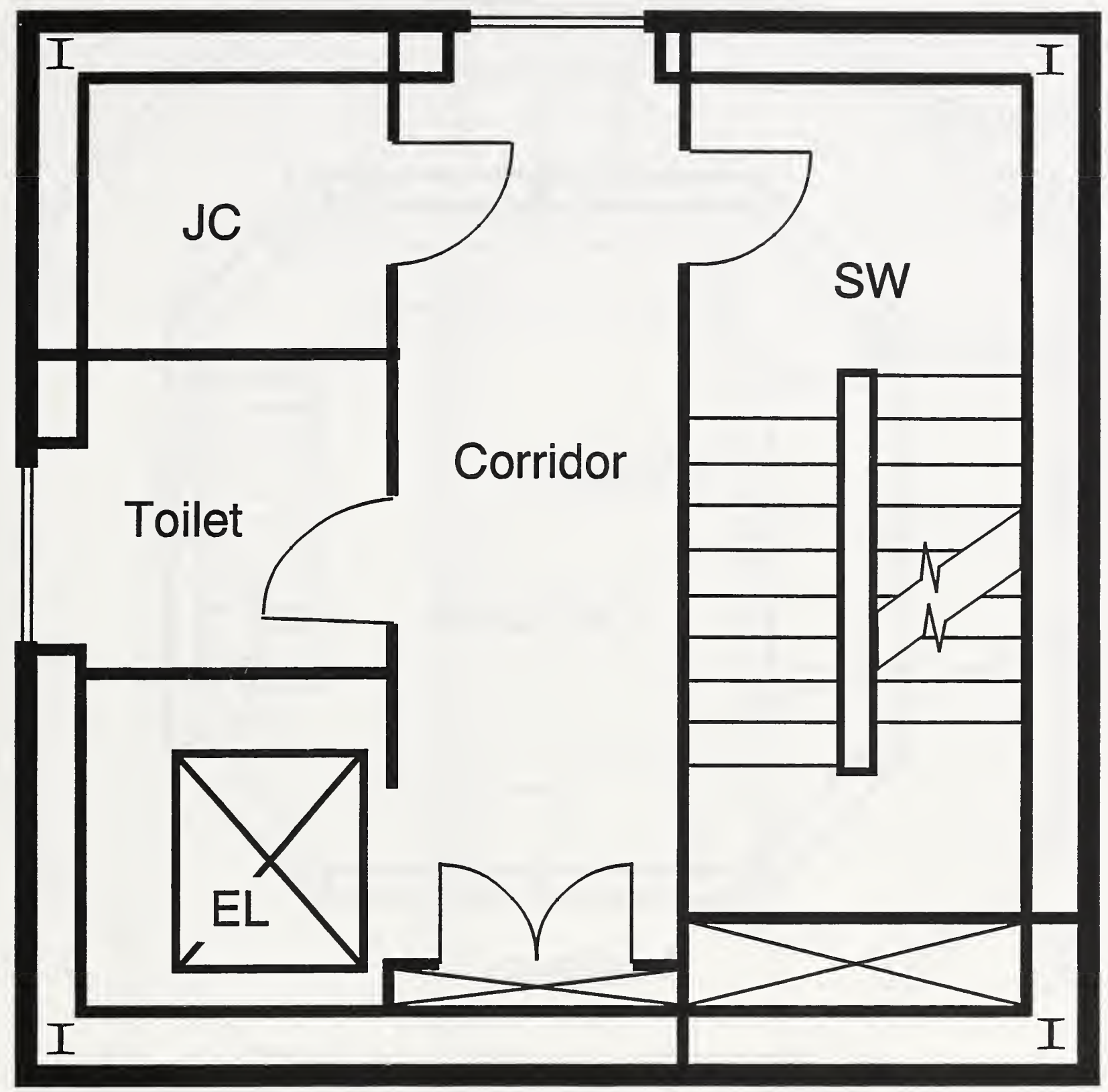

Figure 53. Junction floor of the Leo Daly Low Activity standard design ATCT 


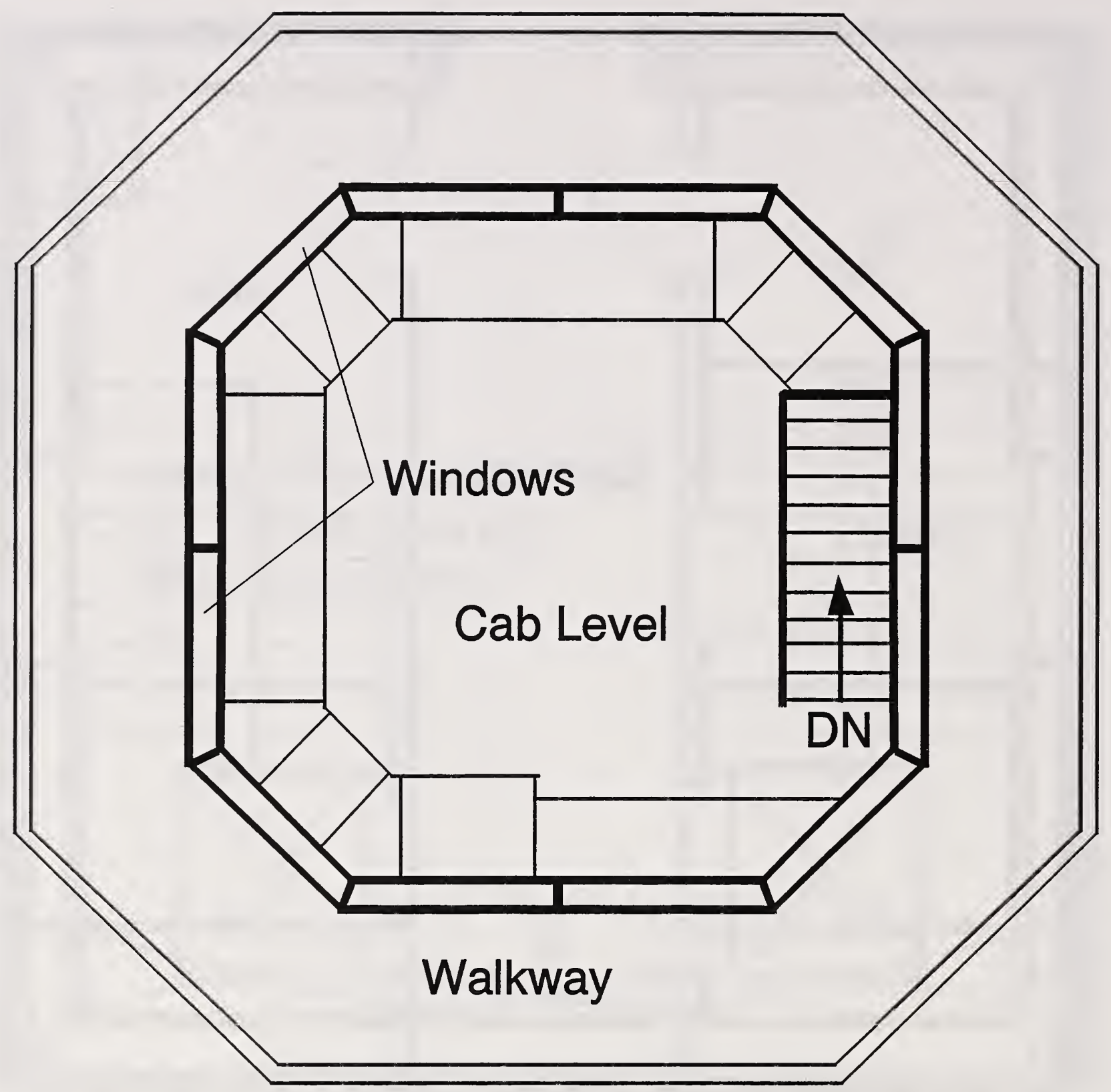

Figure 54. Cab floor of the Leo Daly Low Activity standard design ATCT 


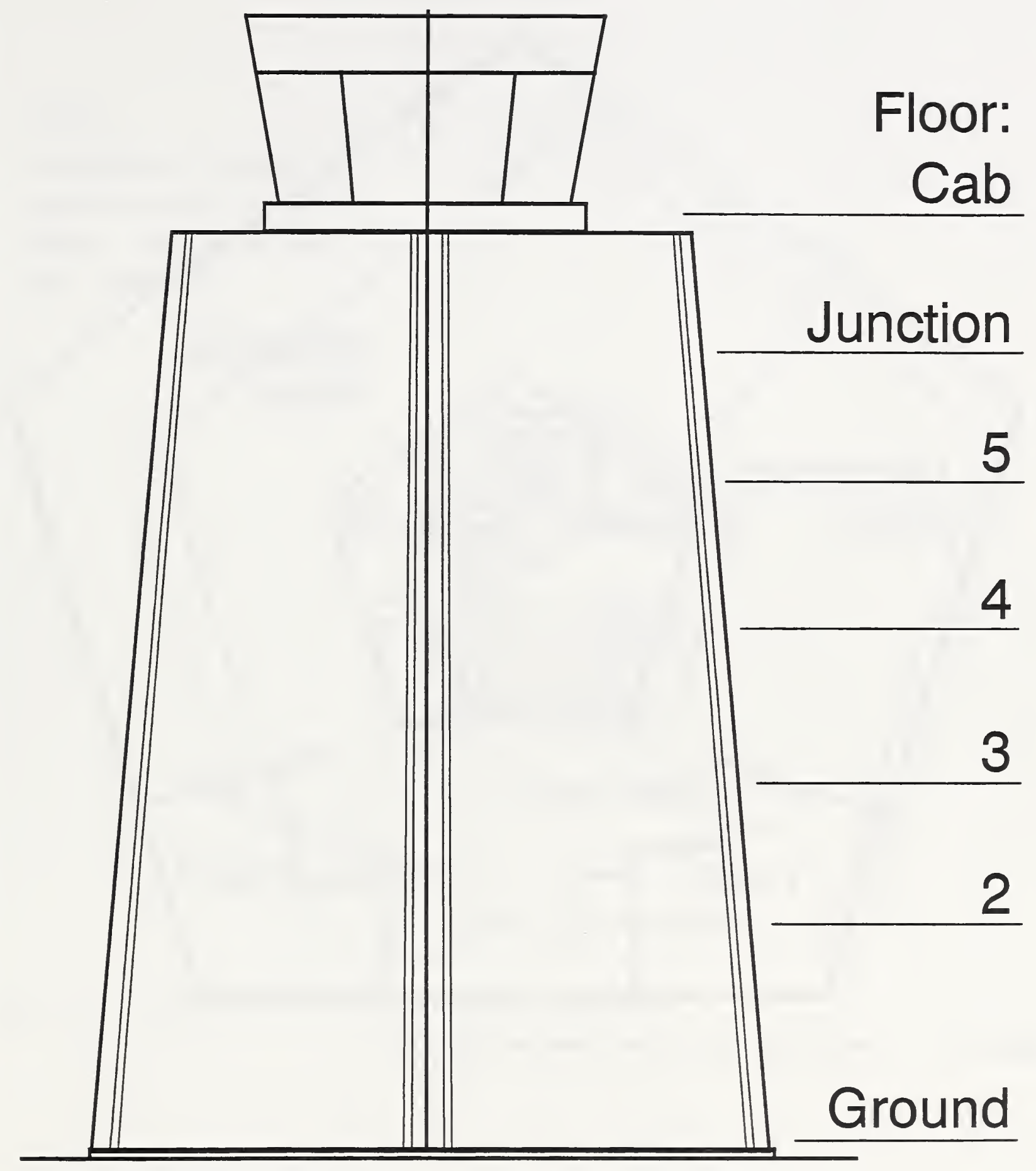

Figure 55. Elevation of the Type O standard design ATCT 


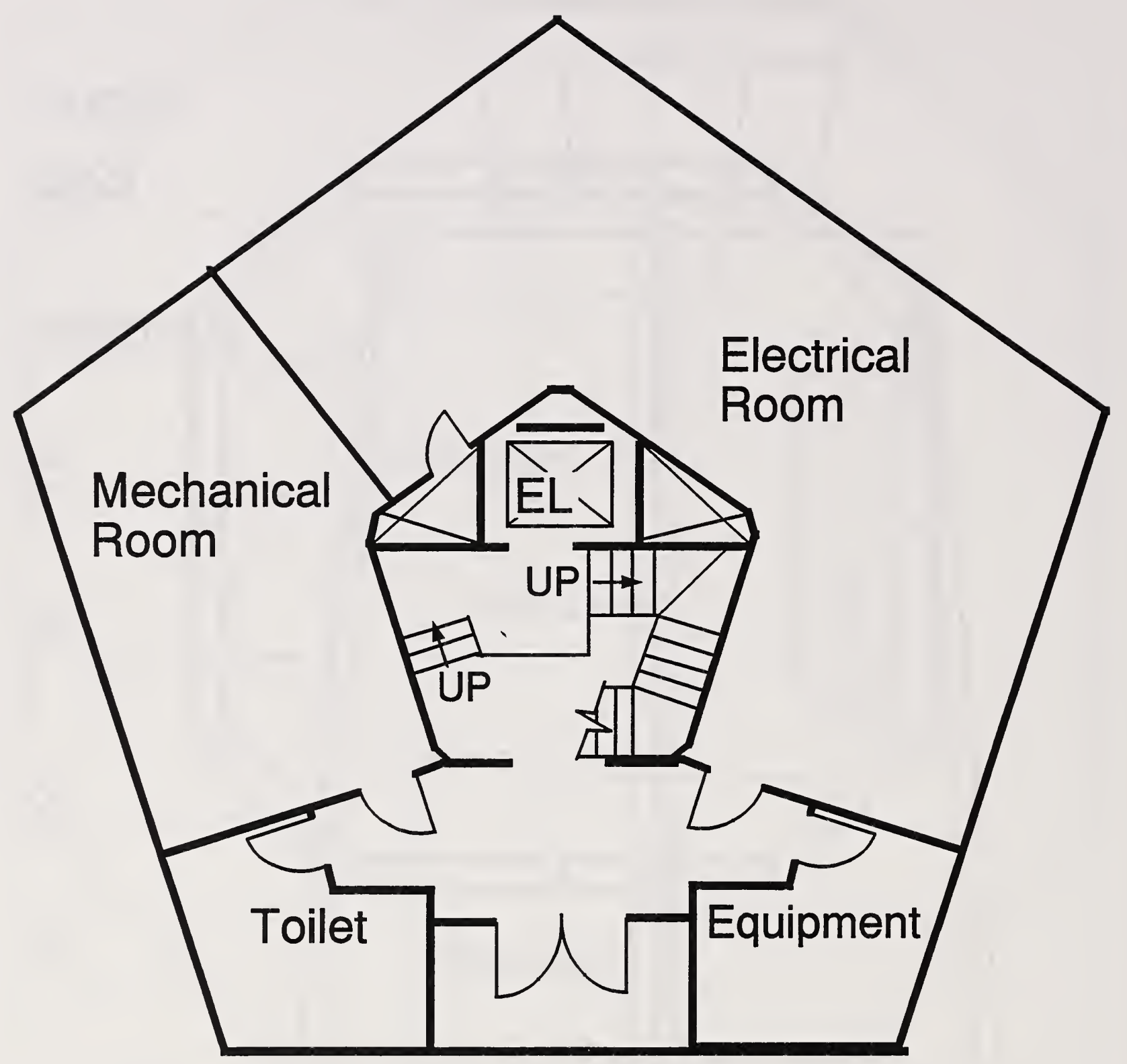

Figure 56. Ground floor of the Type O standard design ATCT 
Note:

Location of exterier walls shown for 2 nd floor. Upper floors are different.

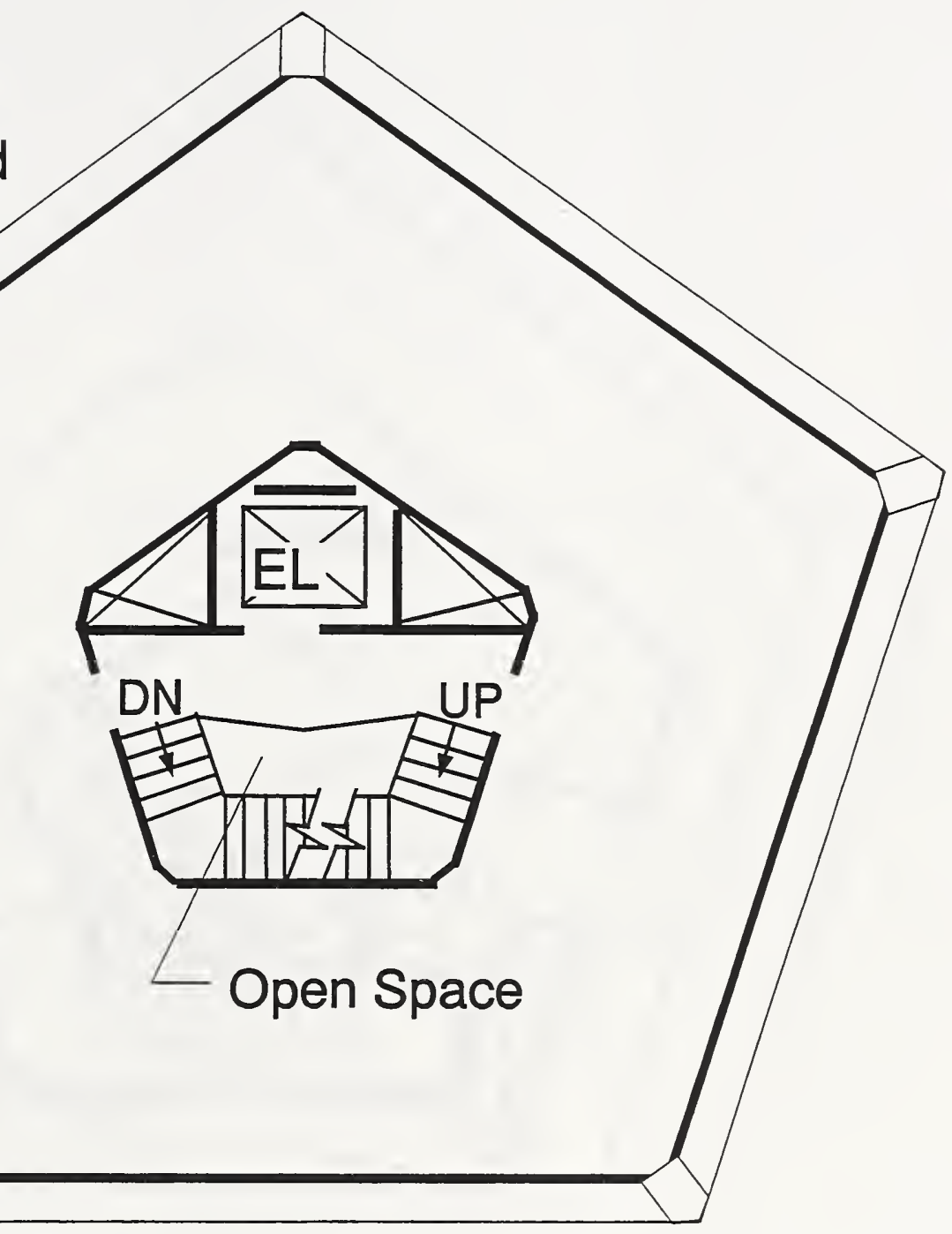

Figure 57. Typical floor of the Type O standard design ATCT 


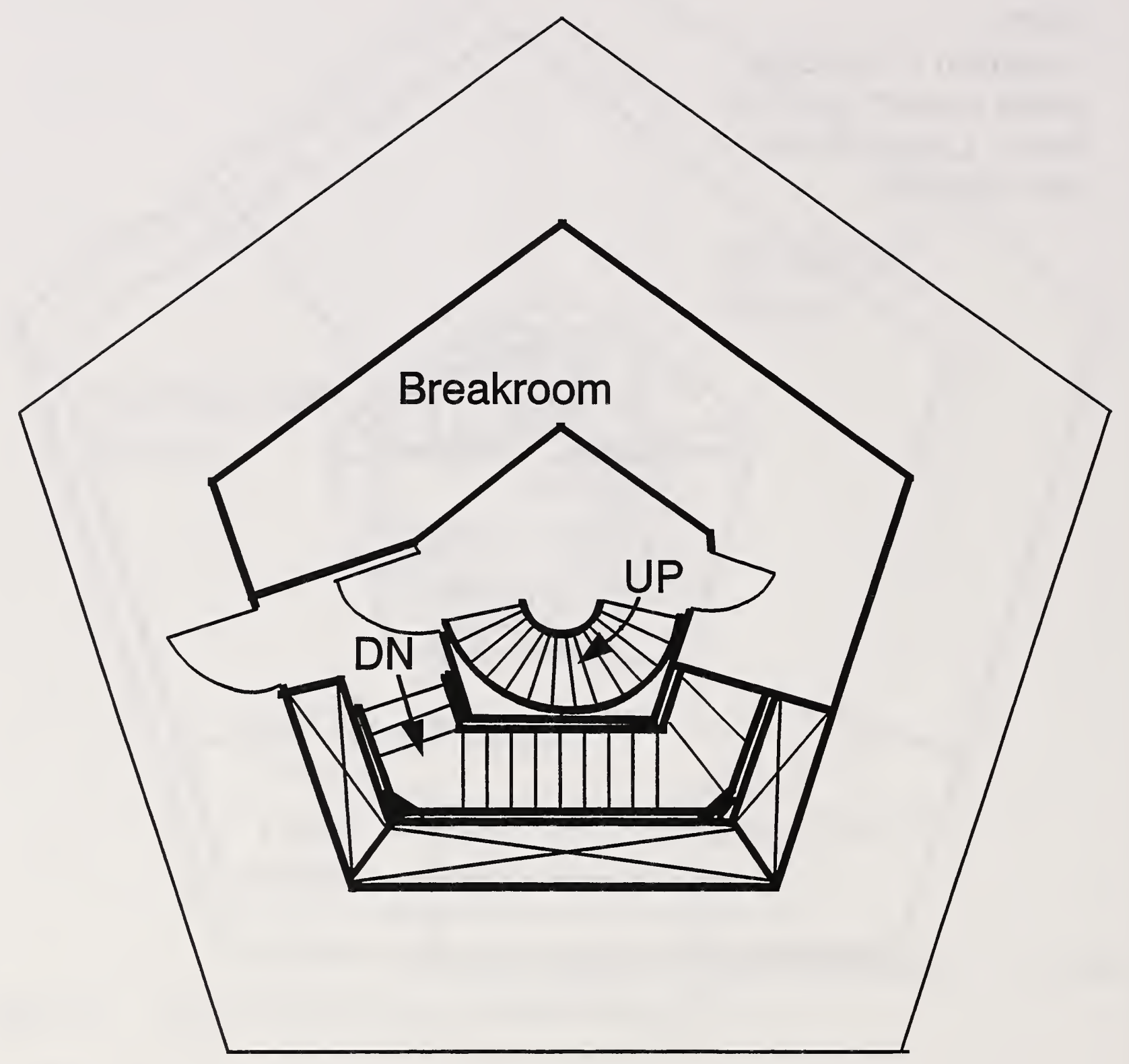

Figure 58. Junction floor of the Type O standard design ATCT 


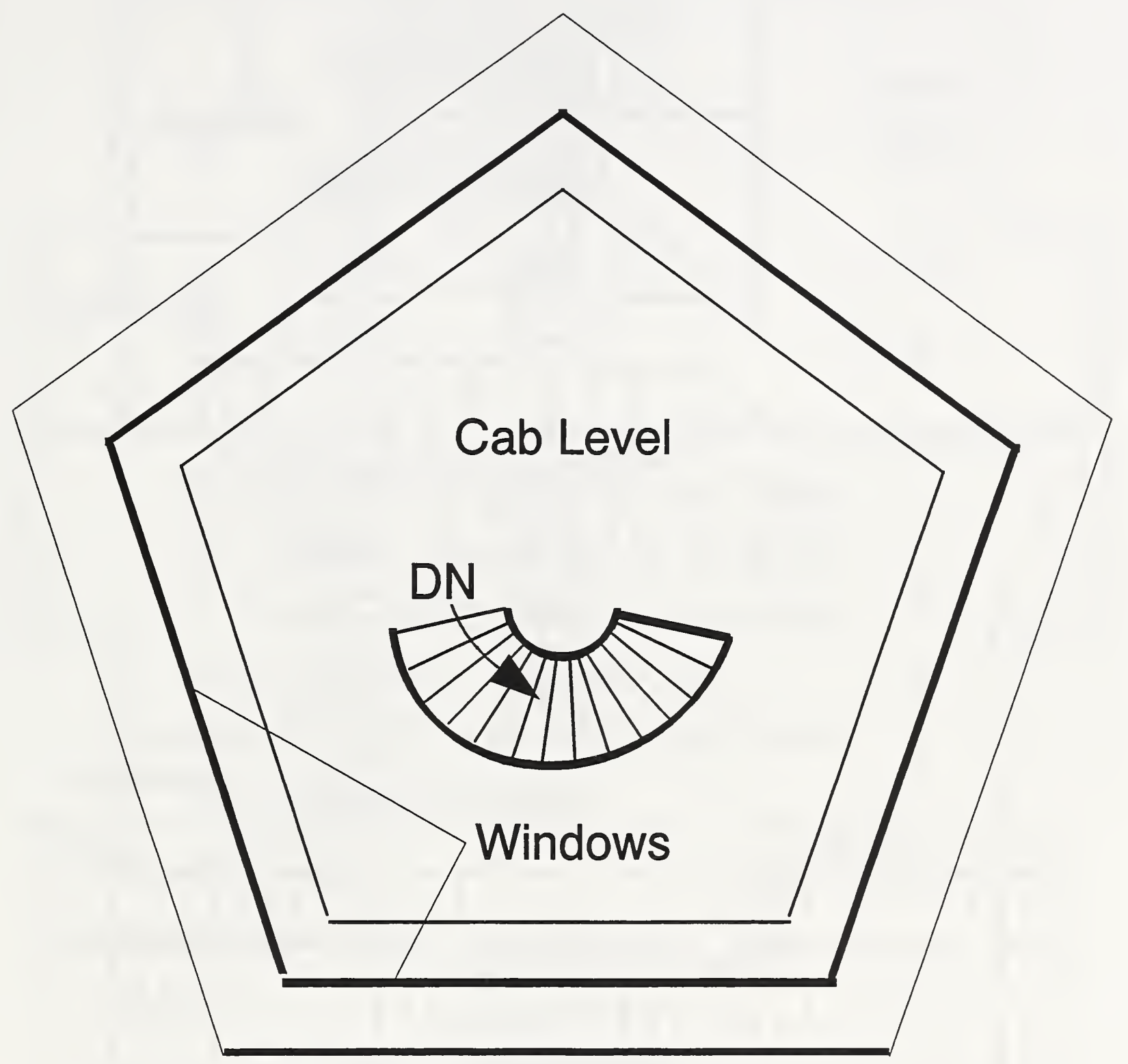

Figure 59. Cab floor of the Type O standard design ATCT 


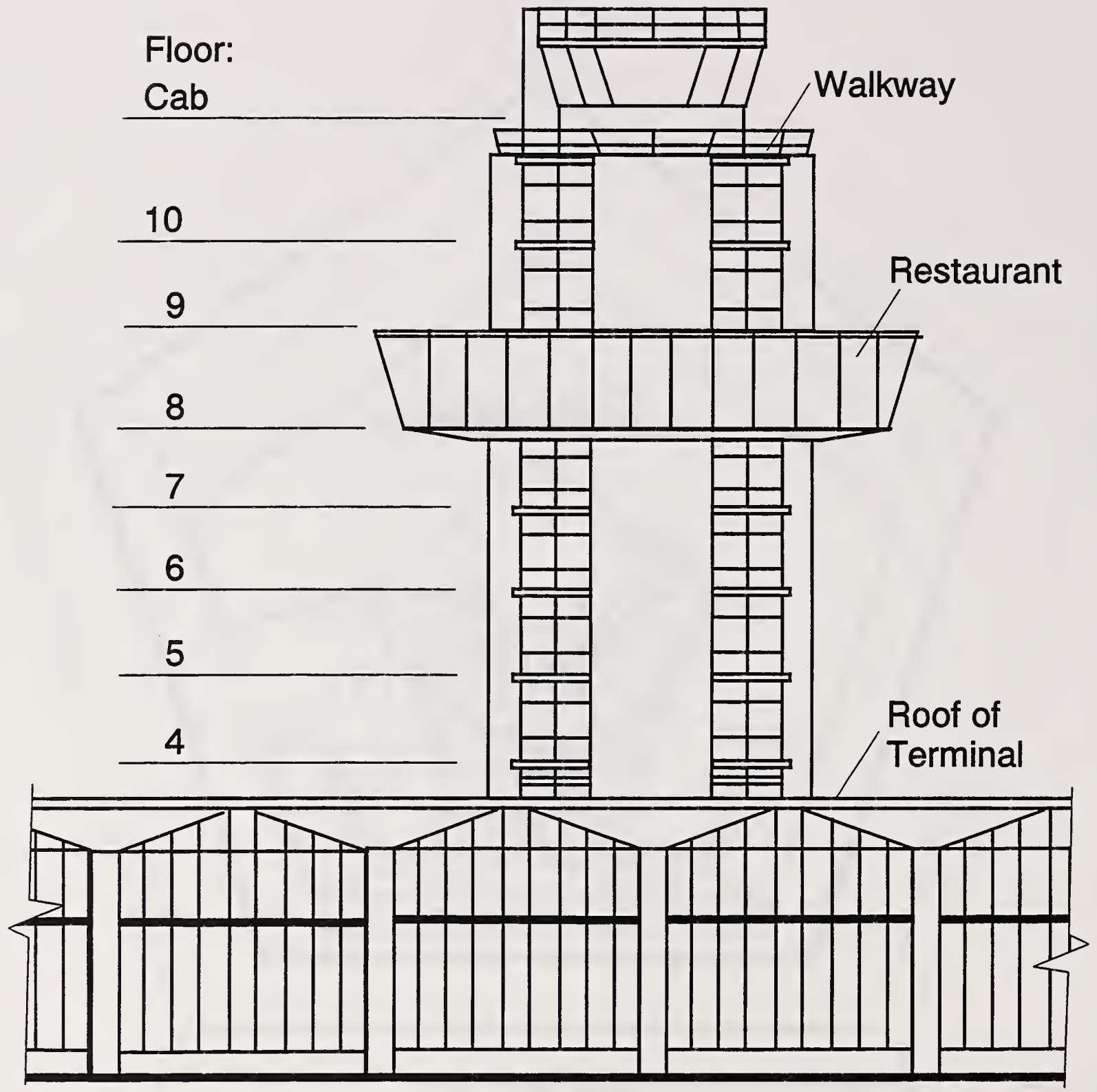

Figure 60. Elevation of the Oakland Metro ATCT 


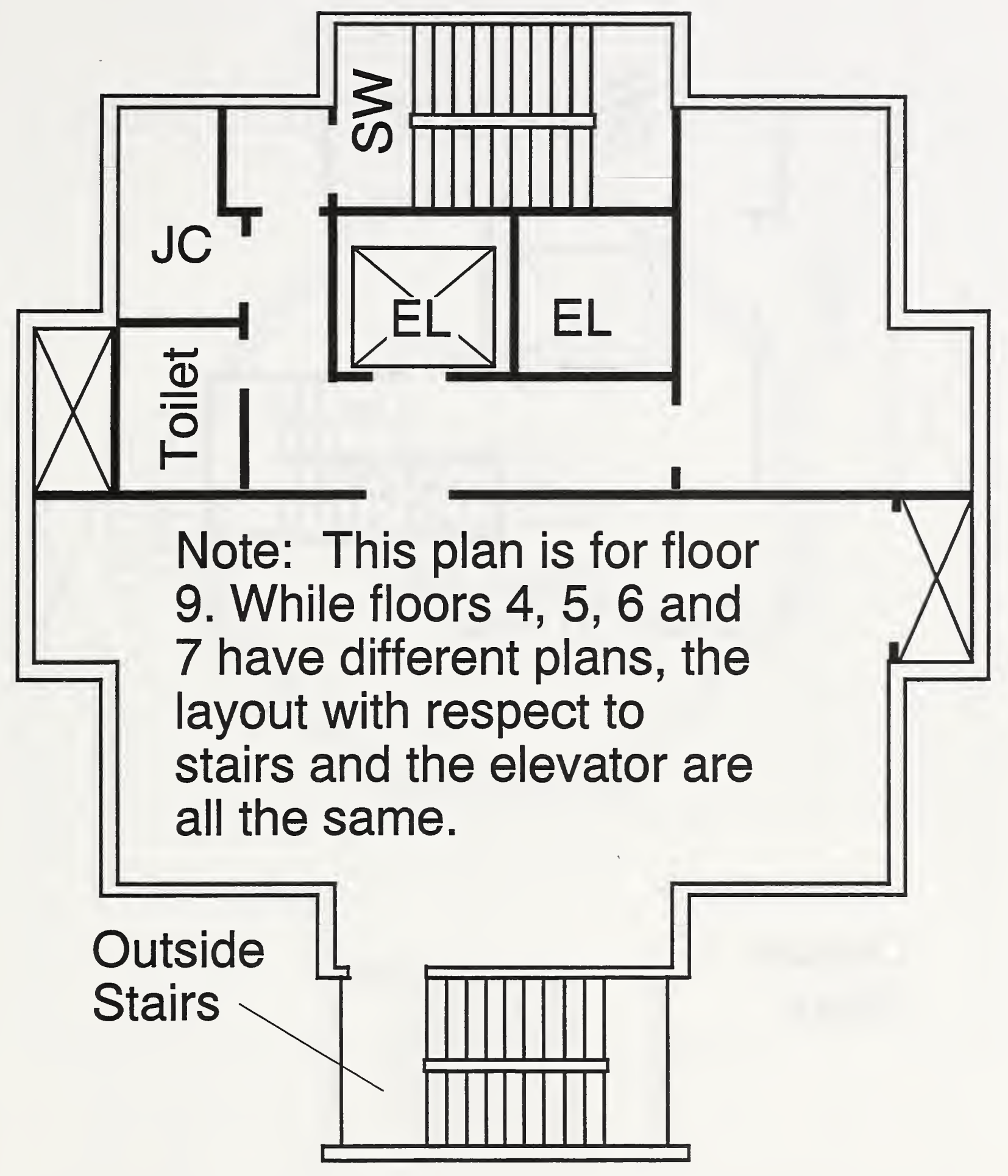

Figure 61. Ninth floor of the Oakland Metro ATCT 


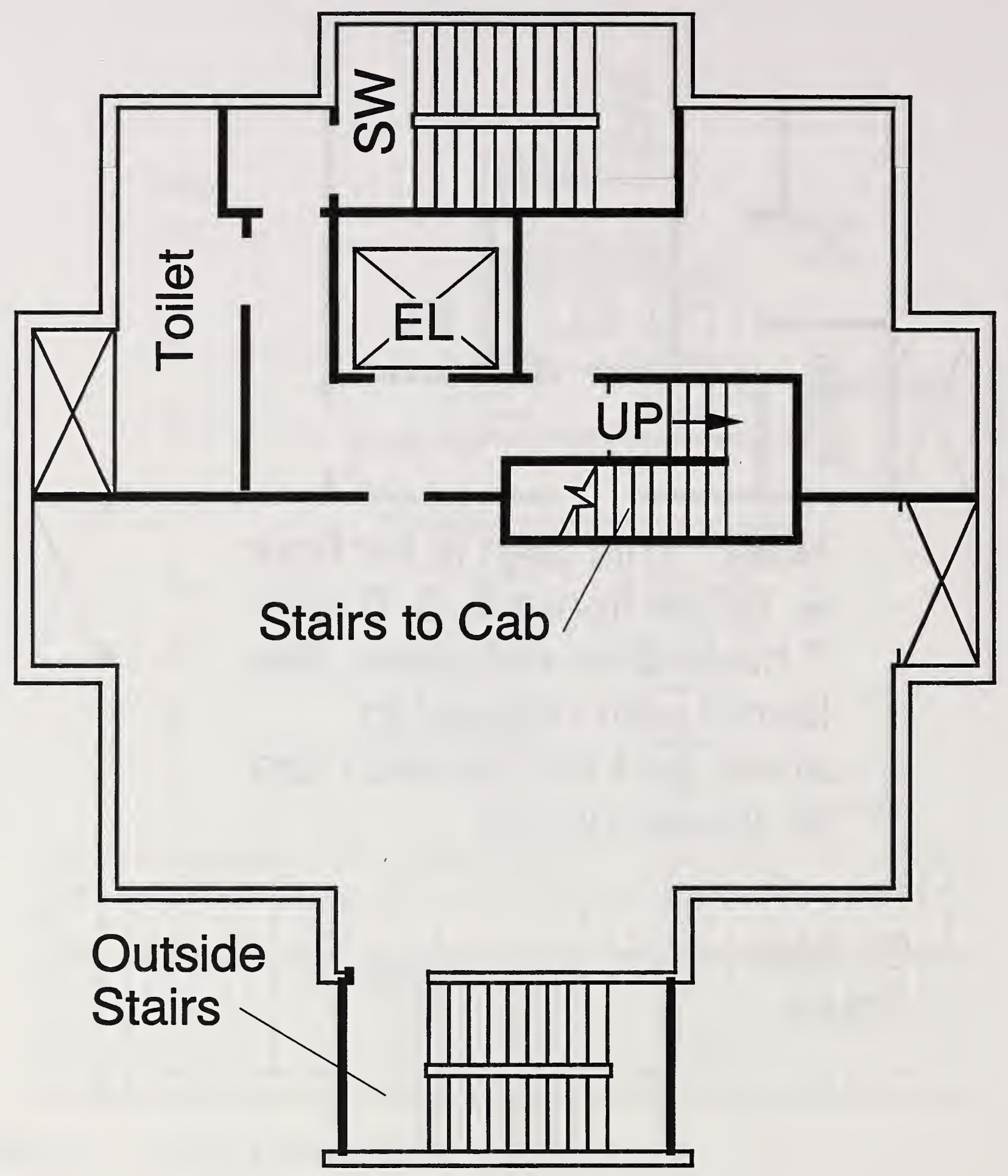

Figure 62. Tenth floor of the Oakland Metro ATCT 


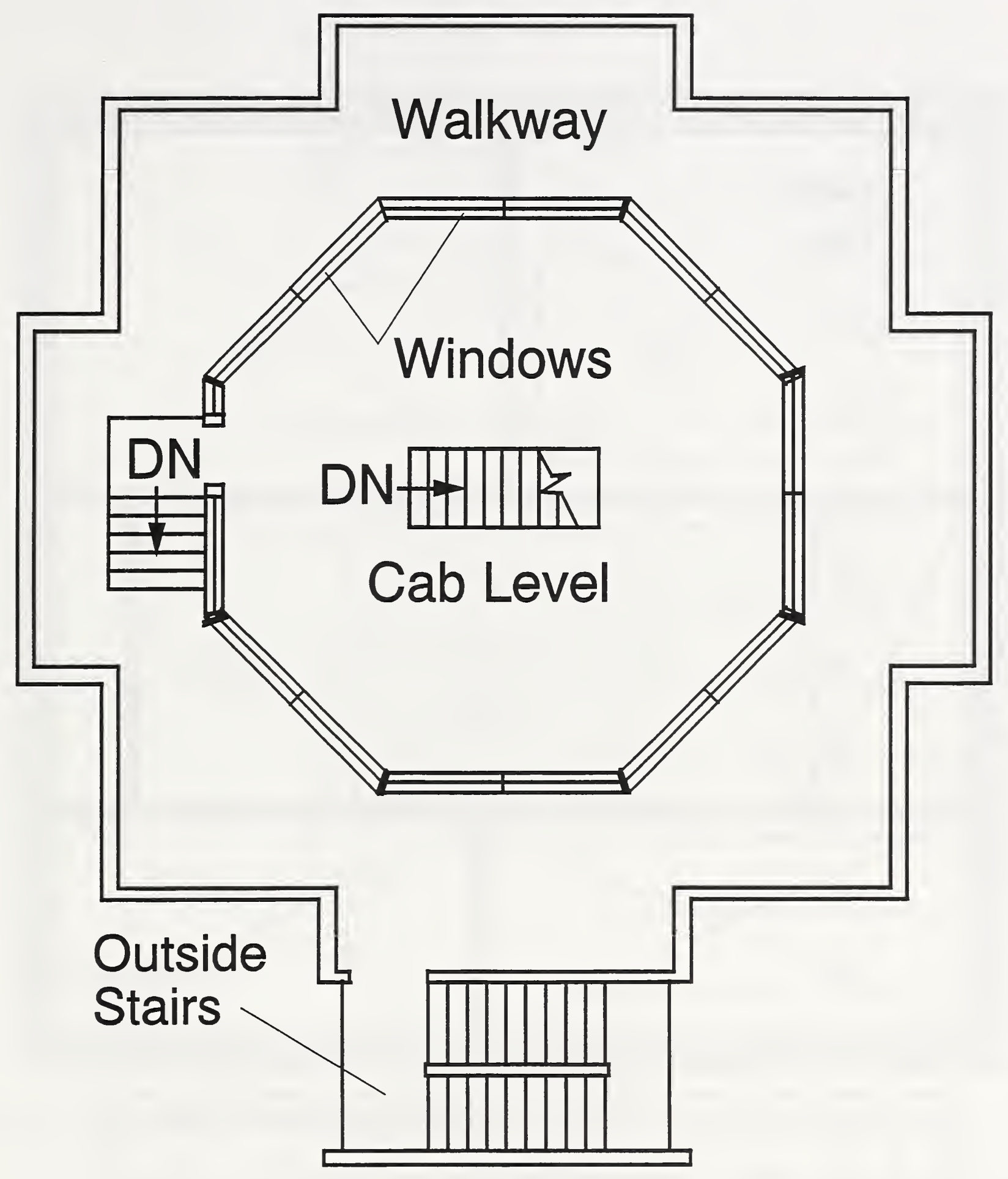

Figure 63. Cab floor of the Oakland Metro ATCT 


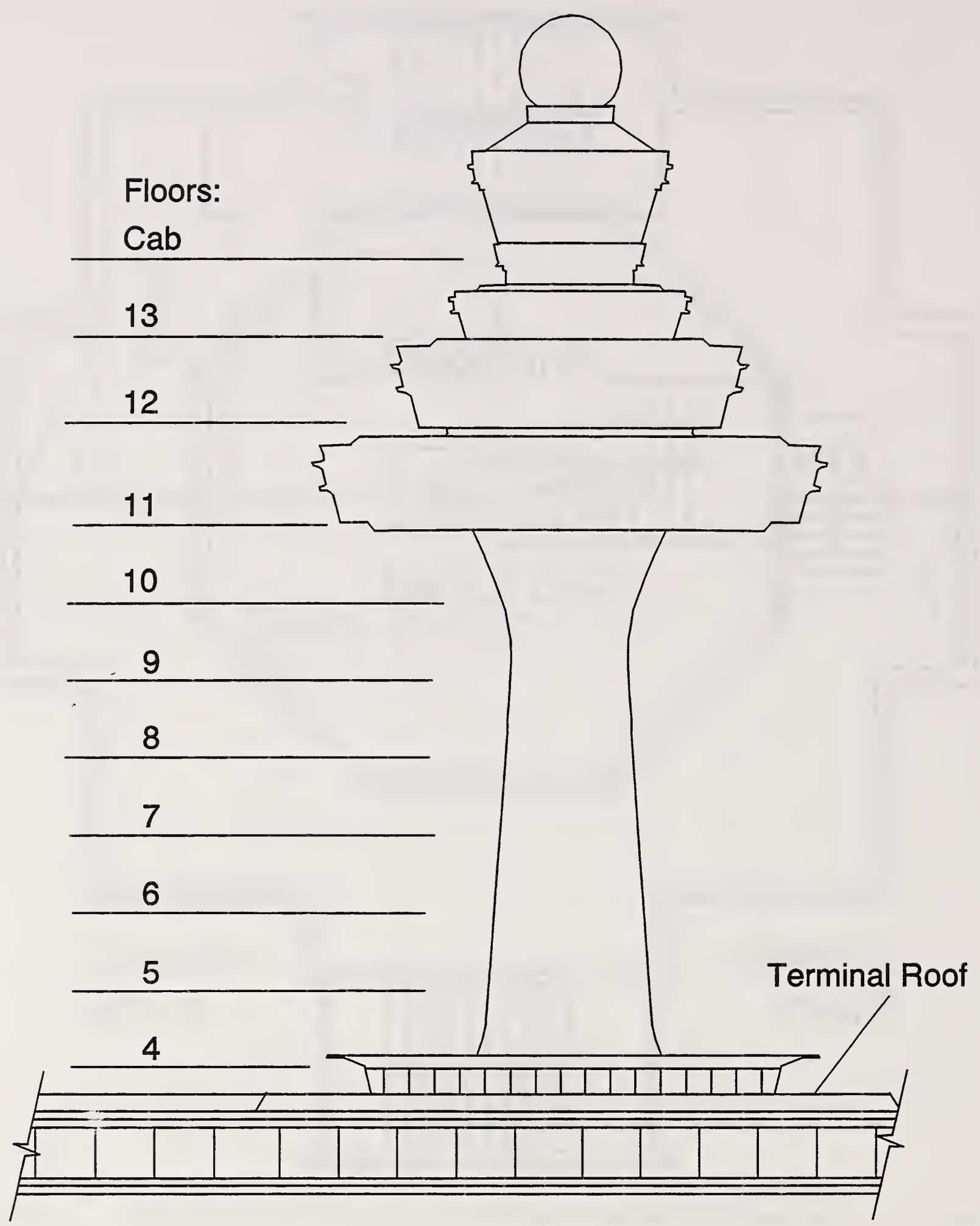

Figure 64. Elevation of the Dulles ATCT 


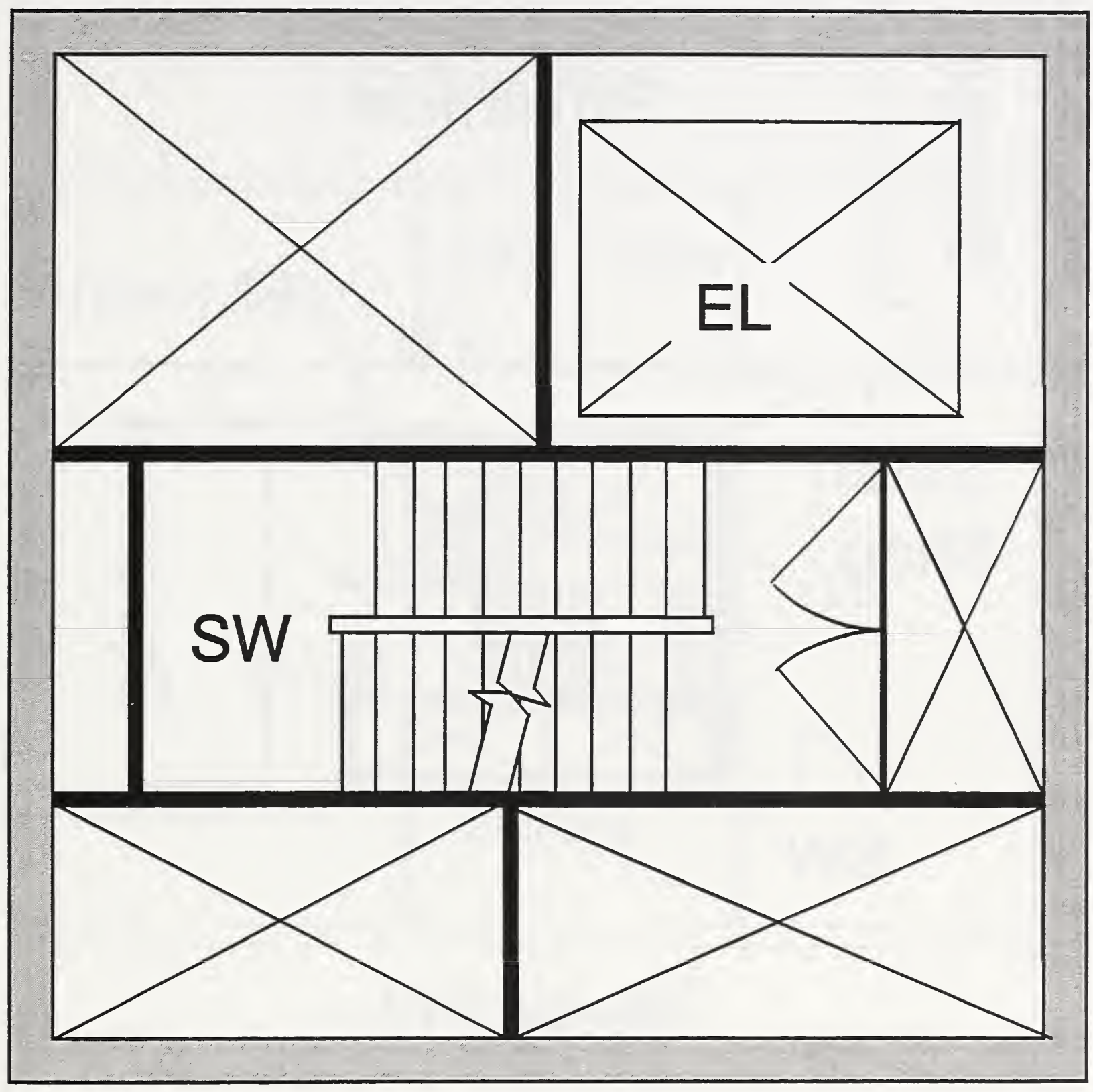

Figure 65. Typical floor of the Dulles ATCT 


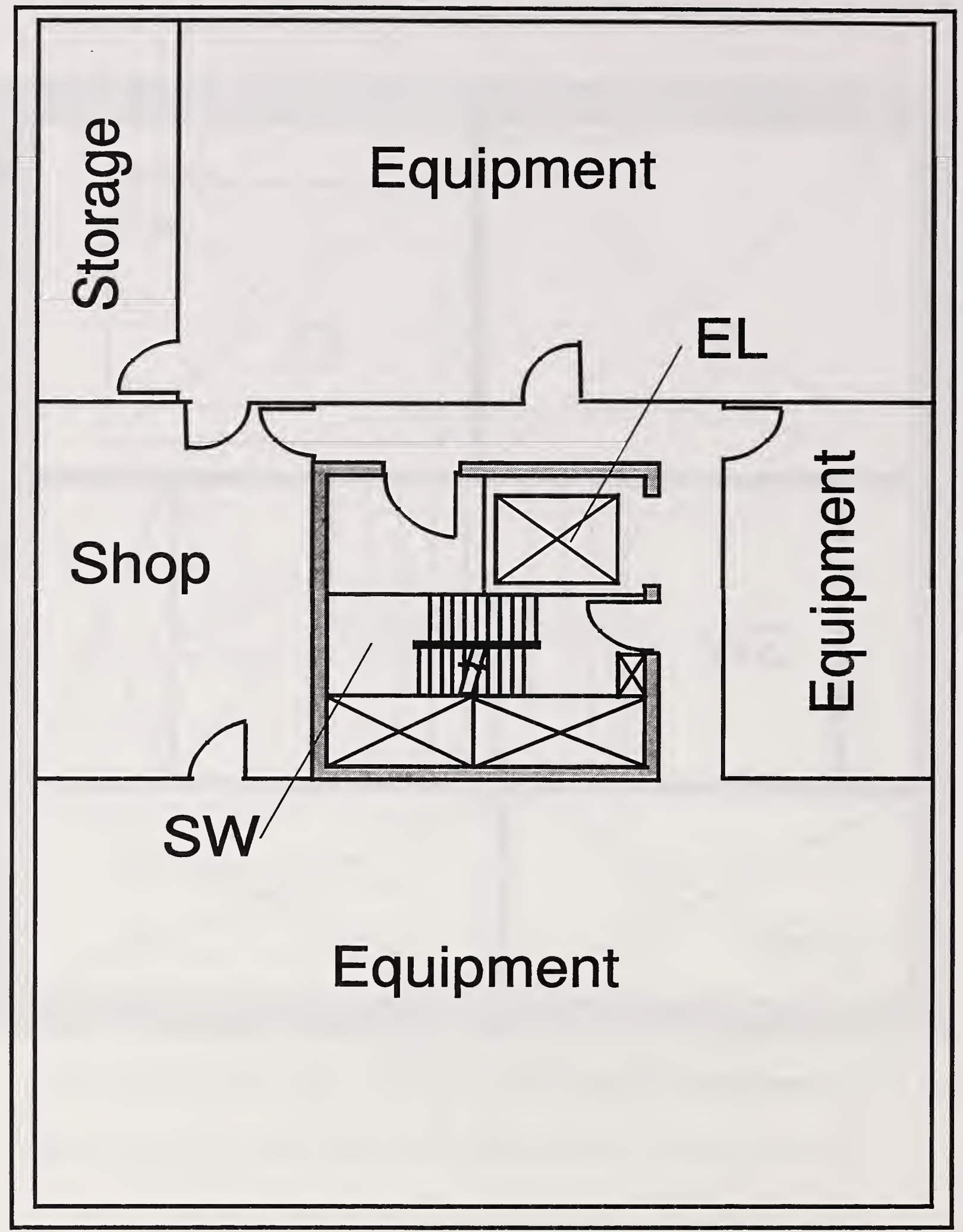

Figure 66. 11th floor of the Dulles ATCT 


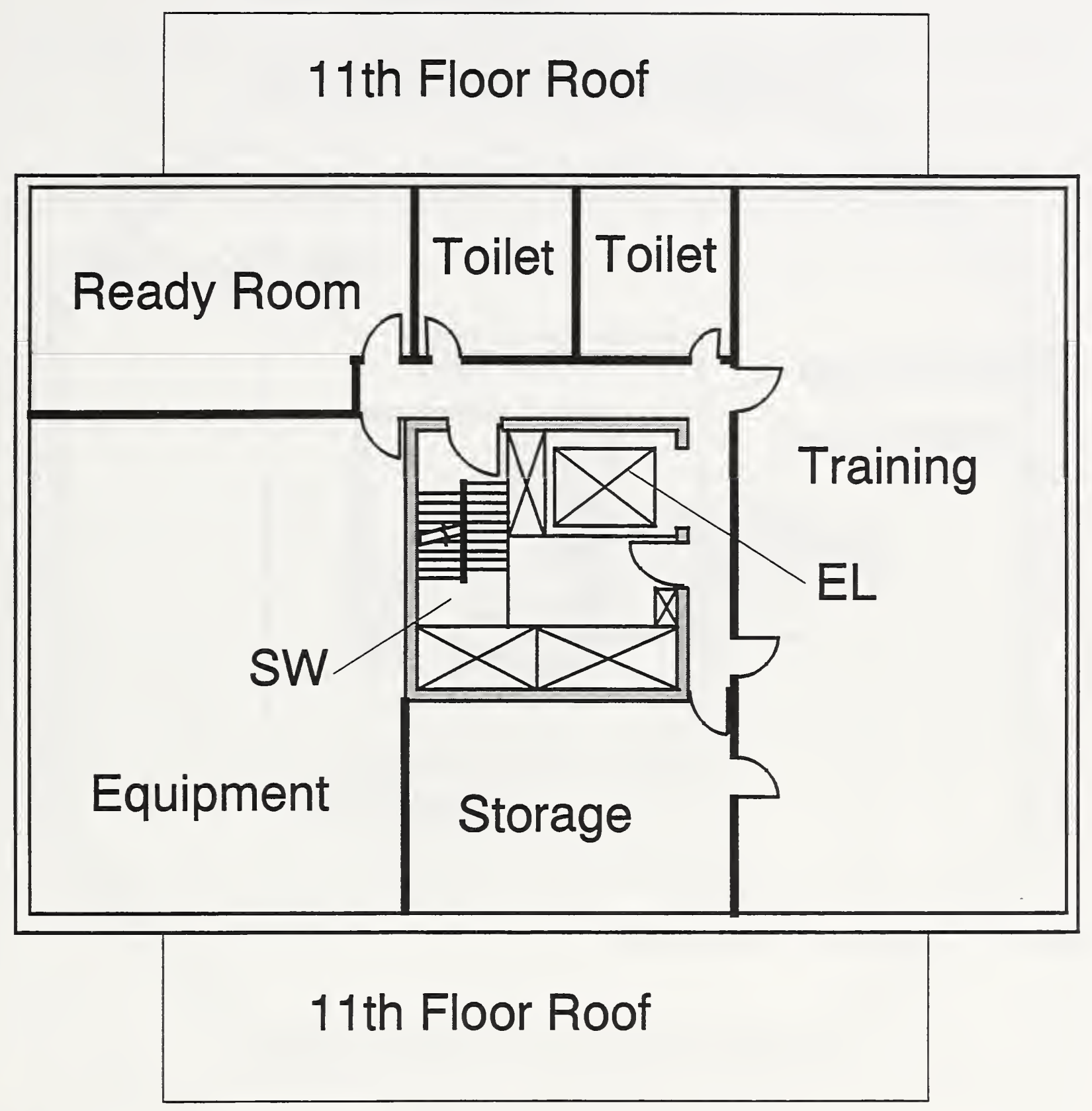

Figure 67. 12th floor of the Dulles ATCT 


\section{2th Floor Roof}

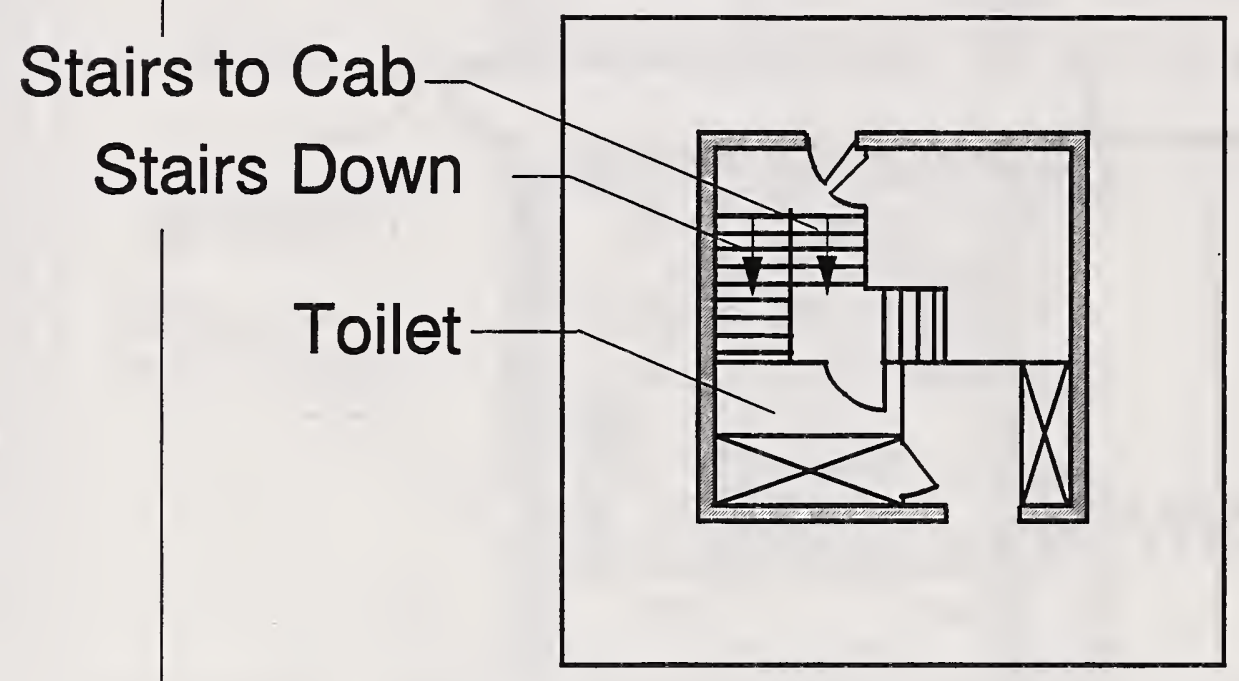

Figure 68. 13th floor of the Dulles ATCT 


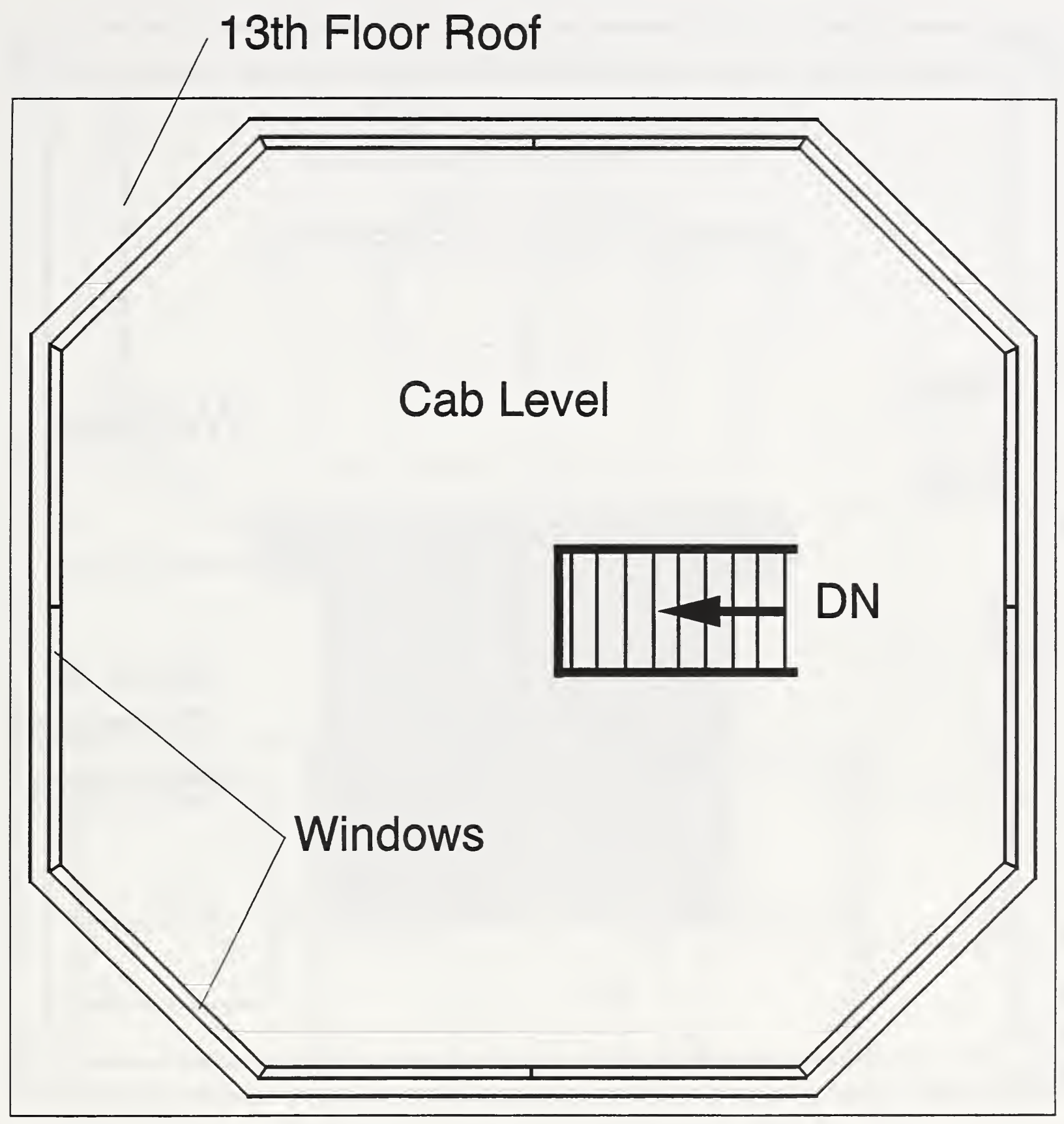

Figure 69. Cab floor of the Dulles ATCT 


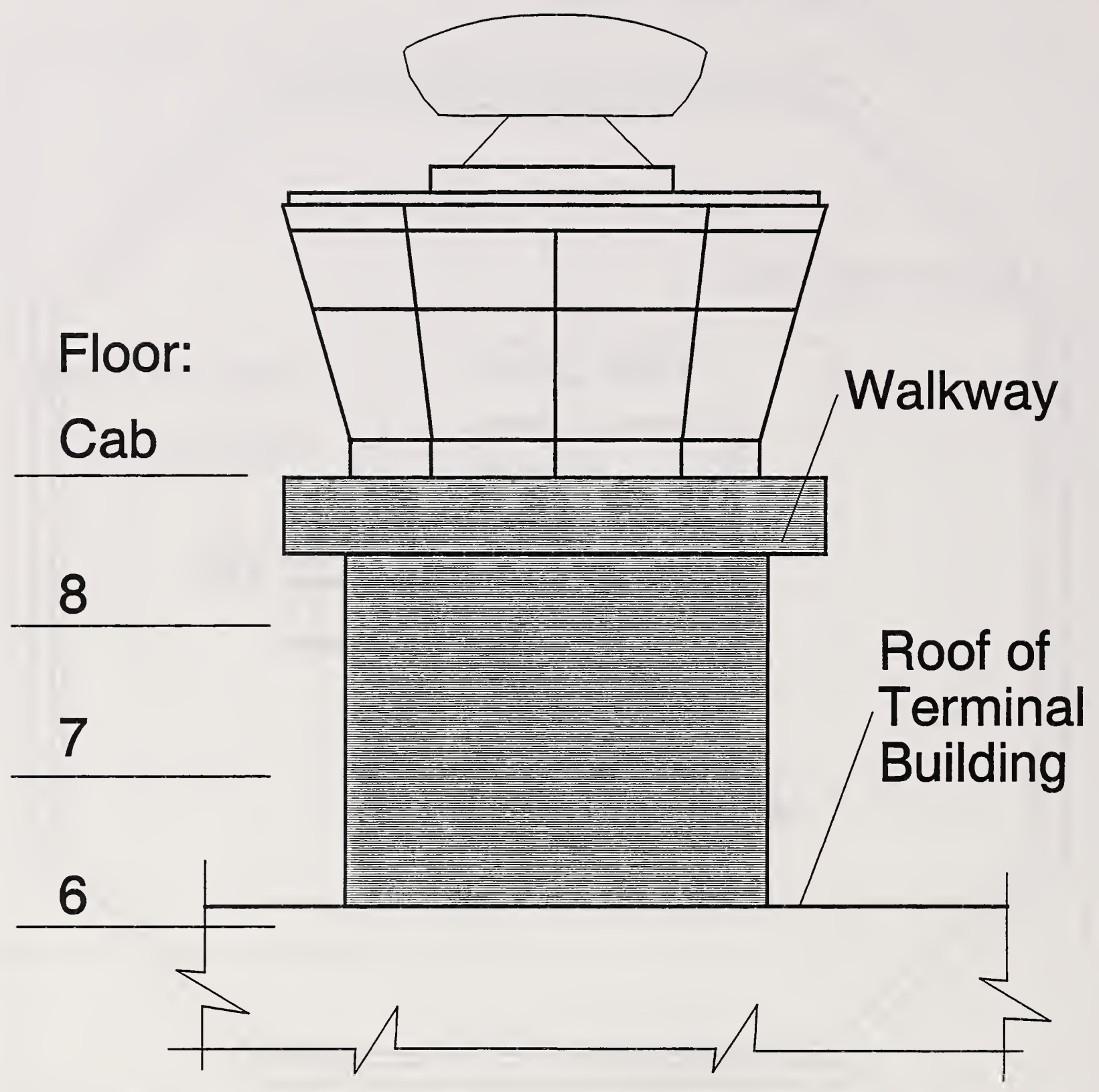

Figure 70. Elevation of the Baltimore Washington International ATCT 


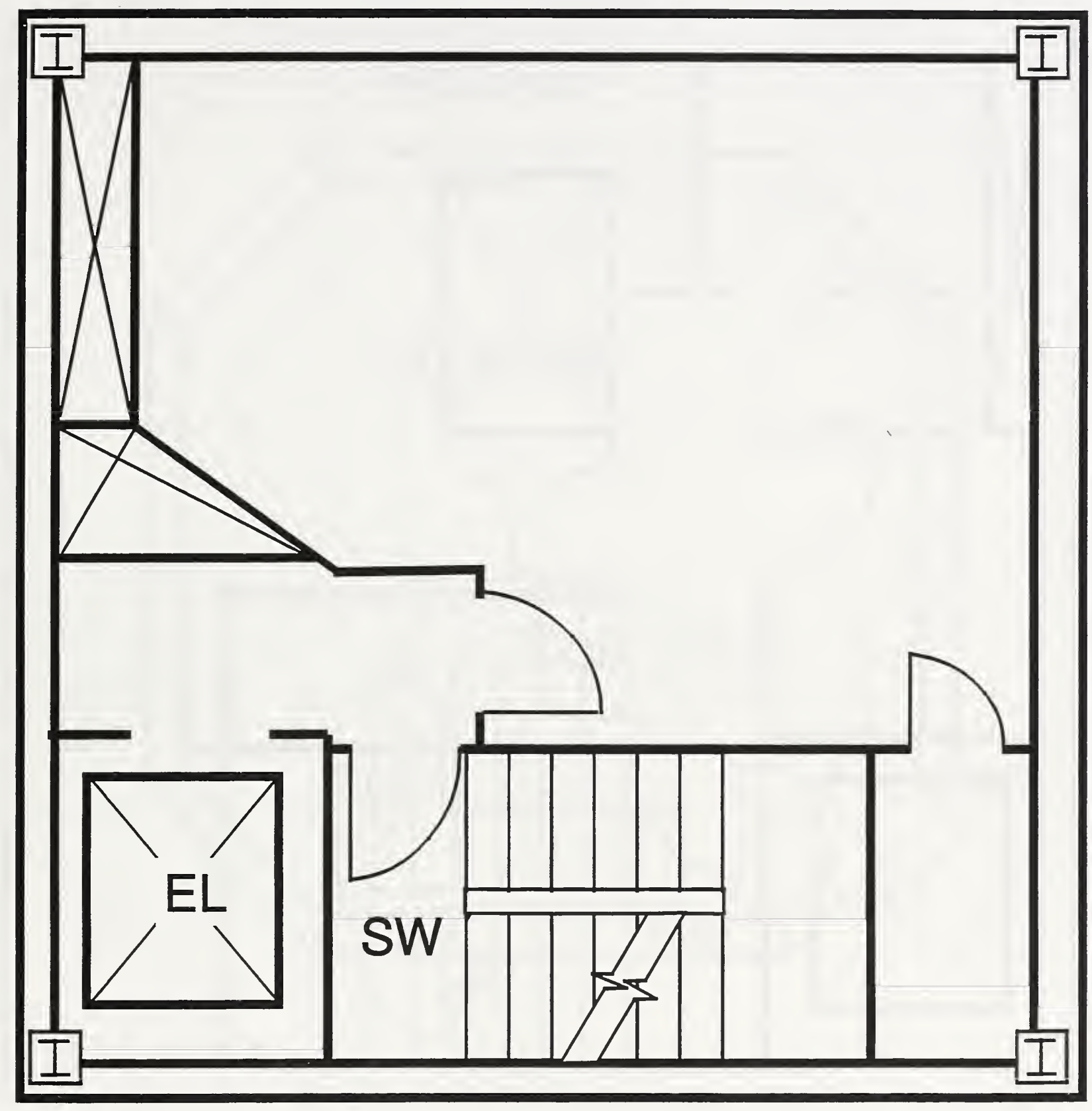

Figure 71. Typical floor of the Baltimore Washington International ATCT 


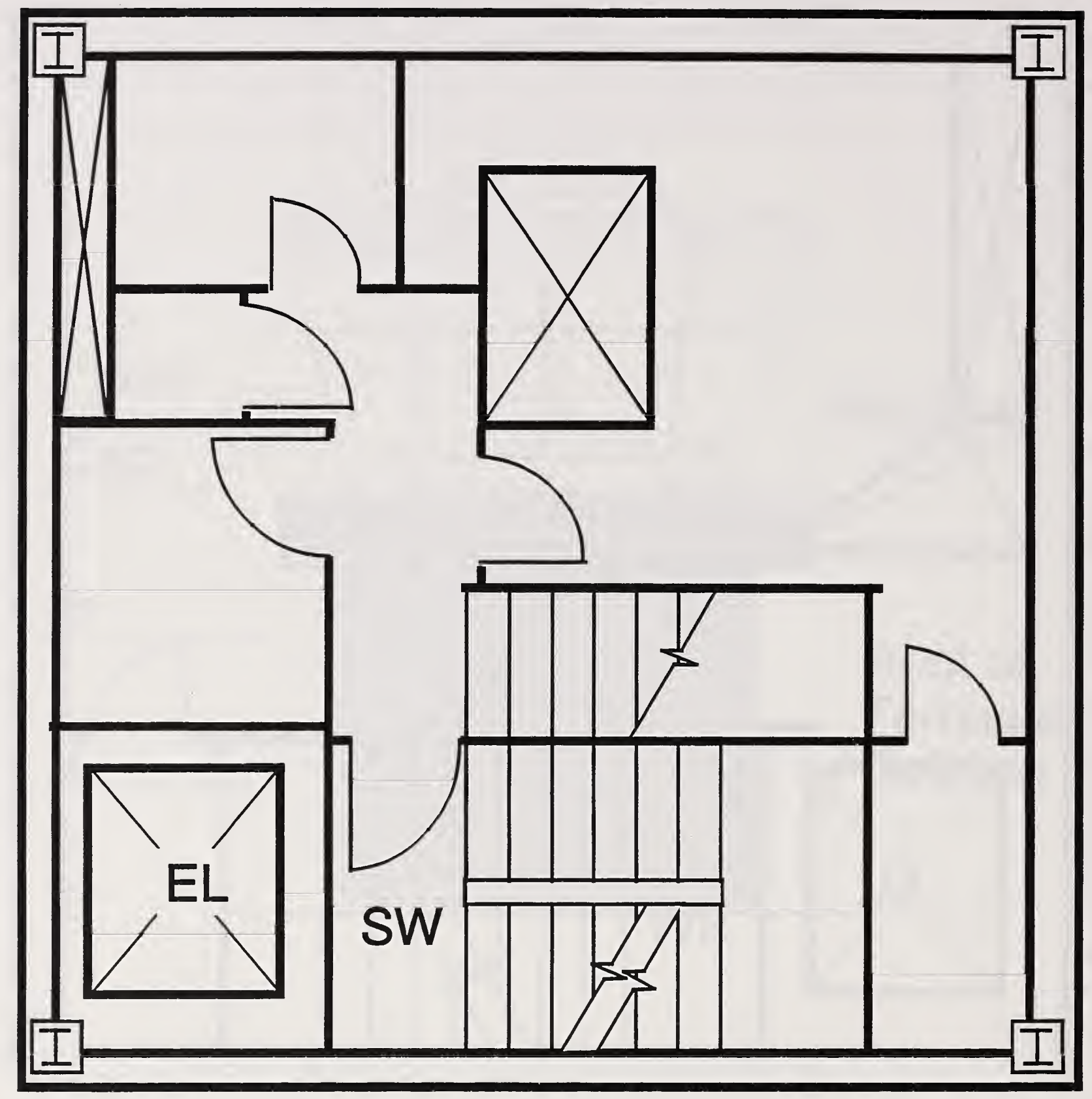

Figure 72. 8th floor of the Baltimore Washington International ATCT 


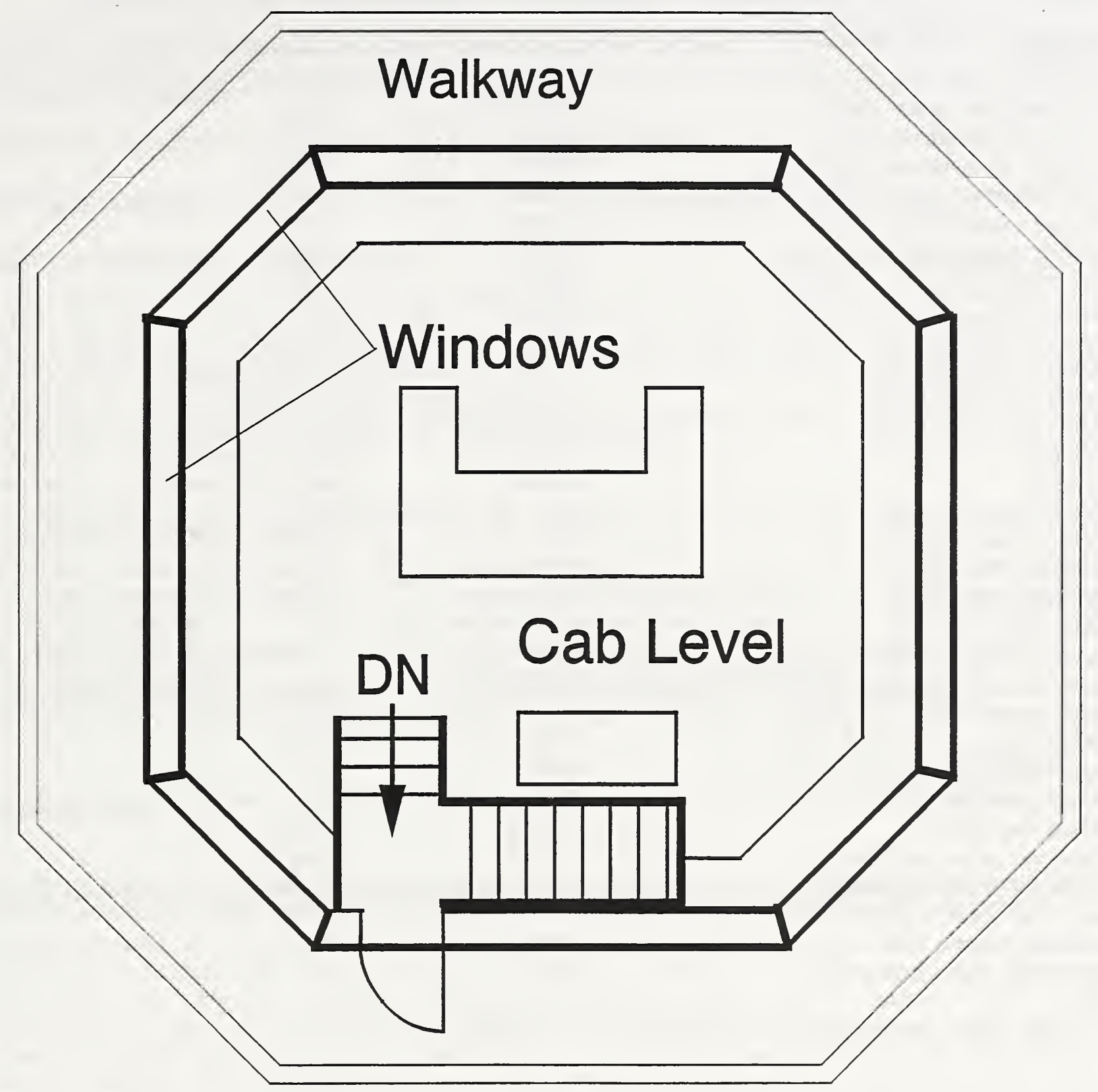

Figure 73. Cab floor of the Baltimore Washington International ATCT 


\section{Appendix A Units of Measurement and Constants}

Table A. Unit conversion factors

\begin{tabular}{|c|c|c|}
\hline Multiply & By & To Obtair \\
\hline foot $(\mathrm{ft})$ & 0.3048 & $\mathrm{~m}$ \\
\hline foot cubed per minute $(\mathrm{cfm})$ & $4.72 \times 10^{-4}$ & $\mathrm{~m}^{3} / \mathrm{s}$ \\
\hline foot cubed per minute (cfm) & 0.472 & $\mathrm{~L}^{*} / \mathrm{s}$ \\
\hline foot cubed per minute (cfm) & 0.01667 & $\mathrm{ft}^{3} / \mathrm{s}$ \\
\hline foot per minute (fpm) & 0.00508 & $\mathrm{~m} / \mathrm{s}$ \\
\hline foot per minute (fpm) & 0.01667 & $\mathrm{ft} / \mathrm{s}$ \\
\hline foot per second $(\mathrm{ft} / \mathrm{s})$ & 0.3048 & $\mathrm{~m} / \mathrm{s}$ \\
\hline foot squared $\left(\mathrm{ft}^{2}\right)$ & 0.0929 & $\mathrm{~m}^{2}$ \\
\hline gallon (US) & $3.79 \times 10^{-3}$ & $\mathrm{~m}^{3}$ \\
\hline gallon (US) & 3.79 & $\mathrm{~L}^{*}$ \\
\hline gallon per minute (gpm) & $6.31 \times 10^{-5}$ & $\mathrm{~m}^{3} / \mathrm{s}$ \\
\hline gallon per minute (gpm) & 7.79 & $\mathrm{~L} / \mathrm{min}$ \\
\hline gallon per minute (gpm) & 0.0631 & $\mathrm{~L} / \mathrm{s}$ \\
\hline inch (in) & 0.0254 & $\mathrm{~m}$ \\
\hline inch (in) & 0.08333 & $\mathrm{ft}$ \\
\hline inch of water (in $\mathrm{H}_{2} \mathrm{O}$ ) & 249. & $\mathrm{~Pa}$ \\
\hline inch of water $\left(\right.$ in $\mathrm{H}_{2} \mathrm{O}$ ) & 5.20 & $\mathrm{lbf} / \mathrm{ft}^{2}$ \\
\hline kilogram force (kgf) & 9.807 & $\mathrm{~N}$ \\
\hline liter per second $\left({ }^{*} \mathrm{~L} / \mathrm{s}\right)$ & 2.119 & $\mathrm{ft}^{3} / \mathrm{s}$ \\
\hline meter (m) & 3.281 & \\
\hline meter cubed per second $\left(\mathrm{m}^{3} / \mathrm{s}\right)$ & 2119 & $\mathrm{ft}^{2} / \mathrm{s}$ \\
\hline meter per second $(\mathrm{m} / \mathrm{s})$ & 3.281 & $\mathrm{ft} / \mathrm{s}$ \\
\hline meter squared $\left(\mathrm{m}^{2}\right)$ & 10.76 & $\mathrm{ft}^{2}$ \\
\hline pascal $(\mathrm{Pa})$ & 0.0209 & $\mathrm{lbf} / \mathrm{ft}^{2}$ \\
\hline pound force (lbf) & 4.445 & $\mathrm{~N}$ \\
\hline pound mass (lbm) & 0.454 & $\mathrm{~kg}$ \\
\hline pound mass (lbm) & 0.03108 & slug \\
\hline pound per cubic foot $\left(1 \mathrm{bm} / \mathrm{ft}^{3}\right)$ & 0.03108 & slug/ $/ \mathrm{ft}^{3}$ \\
\hline pound per cubic foot $\left(\mathrm{lbm} / \mathrm{ft}^{3}\right)$ & 16.0 & $\mathrm{~kg} / \mathrm{m}^{3}$ \\
\hline pound per square inch (psi) & 144 & $\mathrm{lbf} / \mathrm{ft}^{2}$ \\
\hline ound per square foot & 47.88 & $\mathrm{~Pa}$ \\
\hline pound per square inch (psi) & 6895. & $\mathrm{~Pa}$ \\
\hline g & 14.59 & $\mathrm{~kg}$ \\
\hline
\end{tabular}




\begin{tabular}{|c|c|c|}
\hline \multirow{4}{*}{$\begin{array}{l}\text { NIST-114 } \\
\text { (REV. 6-93) } \\
\text { ADMAN 4.09 } \\
\text { MANU }\end{array}$} & \multicolumn{2}{|c|}{ ERB USE ONLY } \\
\hline & \multirow[t]{2}{*}{ ERB CONTROL NUMBEA } & DMVION \\
\hline & & \\
\hline & $\begin{array}{l}\text { PUBUCATION REPORT NUMBER } \\
\text { NISTIR } 5445\end{array}$ & CATEGORY CODE \\
\hline $\begin{array}{l}\text { INSTRUCTIONS: ATTACH ORIGINAL OF THIS FORM TO ONE (1) COPY OF WLANI } \\
\text { THE SECRETARY, APPROPRLATE EOITORLLL REVIEW BOARD. }\end{array}$ & $\begin{array}{l}\text { PUBLCATION DATE } \\
\text { August } 1994\end{array}$ & SER PRINTED PAGES \\
\hline
\end{tabular}
TITLE AND SUBTITLE (CITE IN FULL)

$\bar{F}$ Feasibility of Fire Evacuation by Elevators at FAA Control Towers

\begin{tabular}{|l|l}
\hline CONTRACT OR GRANT NUMBER & TYPE OF REPORT AND/OR PERIOD COVERED
\end{tabular}

\begin{tabular}{|l|l|l|}
\hline AUTHOR(S) (LAST NAME, FIRST INITLLL SECOND INITLAL) & PERFORMINO ORGANIZATION (CHECK $X$ ONE BOX) \\
\hline
\end{tabular}

Klote, John H., NIST, Gaithersburg, MD $20899 \quad$ X Mist/Camtheasburo

Levin, Bernard M., George Mason Univ., Fairiax, VA 22030 NIST/BOULER

Groner, Norman E. George Mason Univ., Fairfax, VA 22030 JIL/BOULEER

LABORATORY AND DIVISION MAMES (FIRST NIST AUTHOR ONLY

Building and Fire Research Laboratory (864)

SPONSORING ORCANIZATION MAME AND COMPLETE ADDRESS (STREET, CTY, STATE, ZIP)

Federal Aviation Administration

Department of Transportation

800 Independence Ave., SW, Washington, DC 20591

PROPOSED FOR NIST PUBLCATION

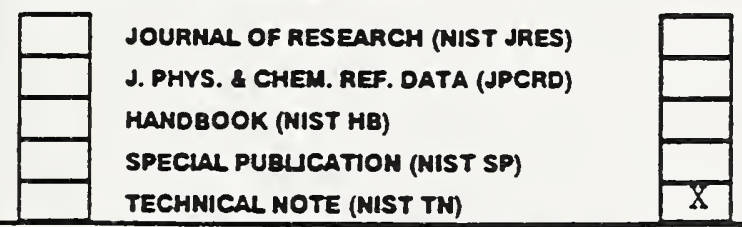

TECHNICAL NOTE (NIST TM)
MONOCRAPH (MIST MN)

MATL STD. REF. DATA SERIES (MIST NSRDS)

FEDERAL INF. PROCESS. STDS. (MIST FIPS)

UST OF PUBUCATIONS (NIST LP)

MIST INTERAGENCY/INTERMAL REPORT (NISTIR)

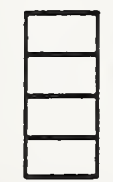

LETTER CIRCULAR BUILINO SCIENCE SERIES PRODUCT STANDAROS OTHER

PROPOSED FOR NONANIST PUBUCATION (CTTE FULLY u.s. FOREION

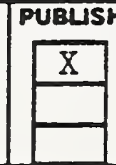

MO MEDIUM

PAPER OISKETTE (SPECIFY) OTHEA (SPECIFY

ABSTAACT (A 2000-CHAAACTER OR LESS FACTUAL SUMMARY OF MOST SIGNIFICANT INFORMATION. IF DOCUMENT INCLUDES A SIGNIFICANT BIBUOGRAPHY OR UTERATURE SURVEY, CTTE IT HERE, SPEU OUT ACRONYWS ON FIRST REFERENCE.) (CONTINUE ON SEPARATE PAGE, IF NECESSARY.)

Throughout most of the world, warning signs next to elevators indicated they should not be used in fire situations. Because these elevators have not been designed for fire evacuation, they should not be used for fire evacuation. However, the idea of using elevators for fire evacuation has gained considerable attention. The Federal Aviation Adminsitration (FAA) has sponsored a project to study the feasibility of elevator emergency evacuation at air traffic control towers. This paper describes this project including (1) a general discussion of elevator evacuation, (2) presentation of conceptual criteria for such elevator evacuation systems, and (3) application of that criteria to several ATCTs.

It is concluded that elevator emergency evacuation is not feasible for existing ATCTs. This could change for some standard designs if water resistant elevator components are developed that make water protection of elevators feasible. However, elevator emergency evacuation is feasible for new ATCTs, and this would involve significant challenges concerning engineering and human factors.

KEY WORDS (MAXIMUM OF 9; 28 CHARACTERS AND SPACES EACH; SEPARATE WITH SEMICOLONS; ALPHABETIC ORDER: CAPITALZE ONLY PROPER NAMES) air traffic control; building fires; elevators (lifts); emergencies; evacuation; handicapped; life safety; smoke control.

AVAILABILTY 


